Portland State University

PDXScholar

9-10-1993

\title{
Modeling of Flow and Water Quality in Henry Hagg Lake near Forest Grove, Oregon
}

Michael T. Knutson

Portland State University

Follow this and additional works at: https://pdxscholar.library.pdx.edu/open_access_etds

Part of the Civil Engineering Commons Let us know how access to this document benefits you.

Recommended Citation

Knutson, Michael T., "Modeling of Flow and Water Quality in Henry Hagg Lake near Forest Grove, Oregon" (1993). Dissertations and Theses. Paper 4600.

https://doi.org/10.15760/etd.6484

This Thesis is brought to you for free and open access. It has been accepted for inclusion in Dissertations and Theses by an authorized administrator of PDXScholar. Please contact us if we can make this document more accessible: pdxscholar@pdx.edu. 
AN ABSTRACT OF THE THESIS OF Michael T. Knutson for the Master of Science in Civil Engineering presented september 10,1993

Title: Modeling of Flow and water quality in Henry Hagg Lake near Forest Grove, Oregon

APPROVED BY THE MEMBERS OF THE THESIS COMMITTEE:
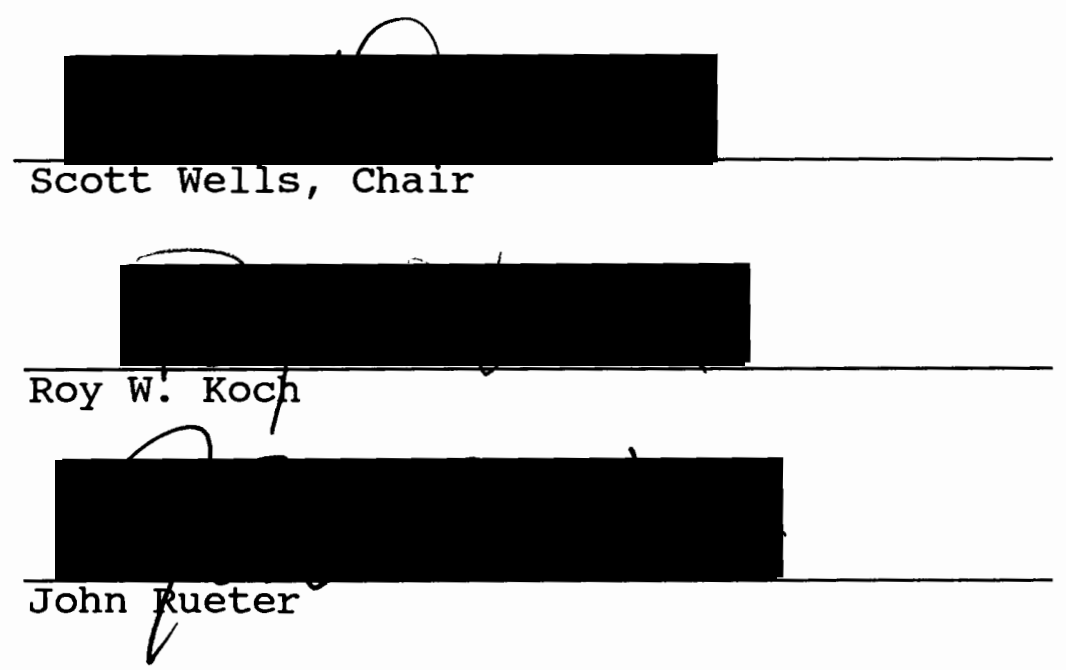

Increased population growth in Washington County, Oregon, has helped cause the water quality of the Tualatin River to decline. Henry Hagg Lake is a storage reservoir which was built to augment summer low flows in the Tualatin River. Hagg Lake also supplies the Tualatin River Basin with both irrigation and municipal water in the summer. Using the U.S. Army Corps of Engineer's model CE-QUAL-W2 (a twodimensional hydrodynamic and water quality model), a model of Henry Hagg Lake was created. The model was calibrated using 
water quality and hydraulic data for 1990 at the Hagg Lake outflow in scoggins creek. A verification simulation was performed with similar field data for 1991. The model was used to evaluate the water quality of Henry Hagg Lake if more flow were allowed out of the reservoir than current allocations permit. This model simulation showed that the water quality of Hagg Lake would not be severely affected, however, recreation in the lake would be. Additional particle sizes for inorganic suspended solids introduced to the lake by streamflow were added to the model. The model was used to track suspended solids in Hagg Lake through a summer season. Field data for the modeling of Hagg Lake were very limited. Thus, firm conclusions about the validity of the model would require further field data. 
MODELING OF FLOW AND WATER QUALITY IN HENRY HAGG LAKE NEAR FOREST GROVE, OREGON

by

MICHAEL T. KNUTSON

A thesis submitted in partial fulfillment of the requirements for the degree of

MASTER OF SCIENCE

in

CIVIL ENGINEERING

Portland State University

1993 
TO THE OFFICE OF GRADUATE STUDIES:

The members of the committee approve the thesis of Michael T. Knutson presented September 10, 1993.
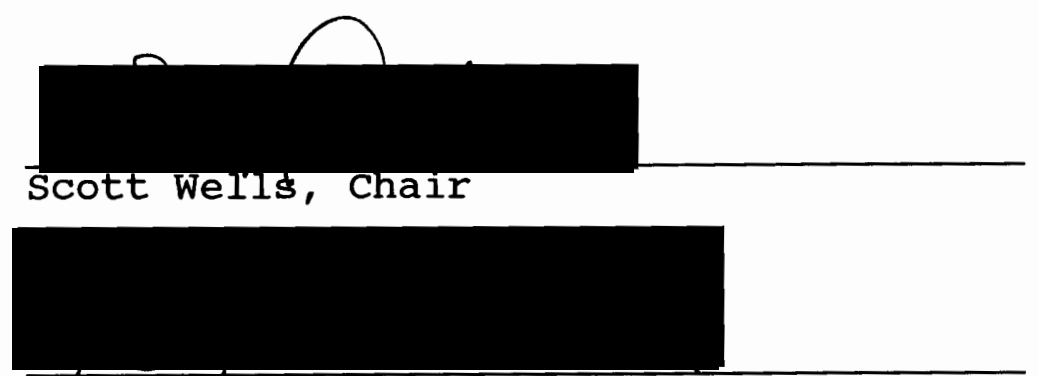

Roy $w$. Foch
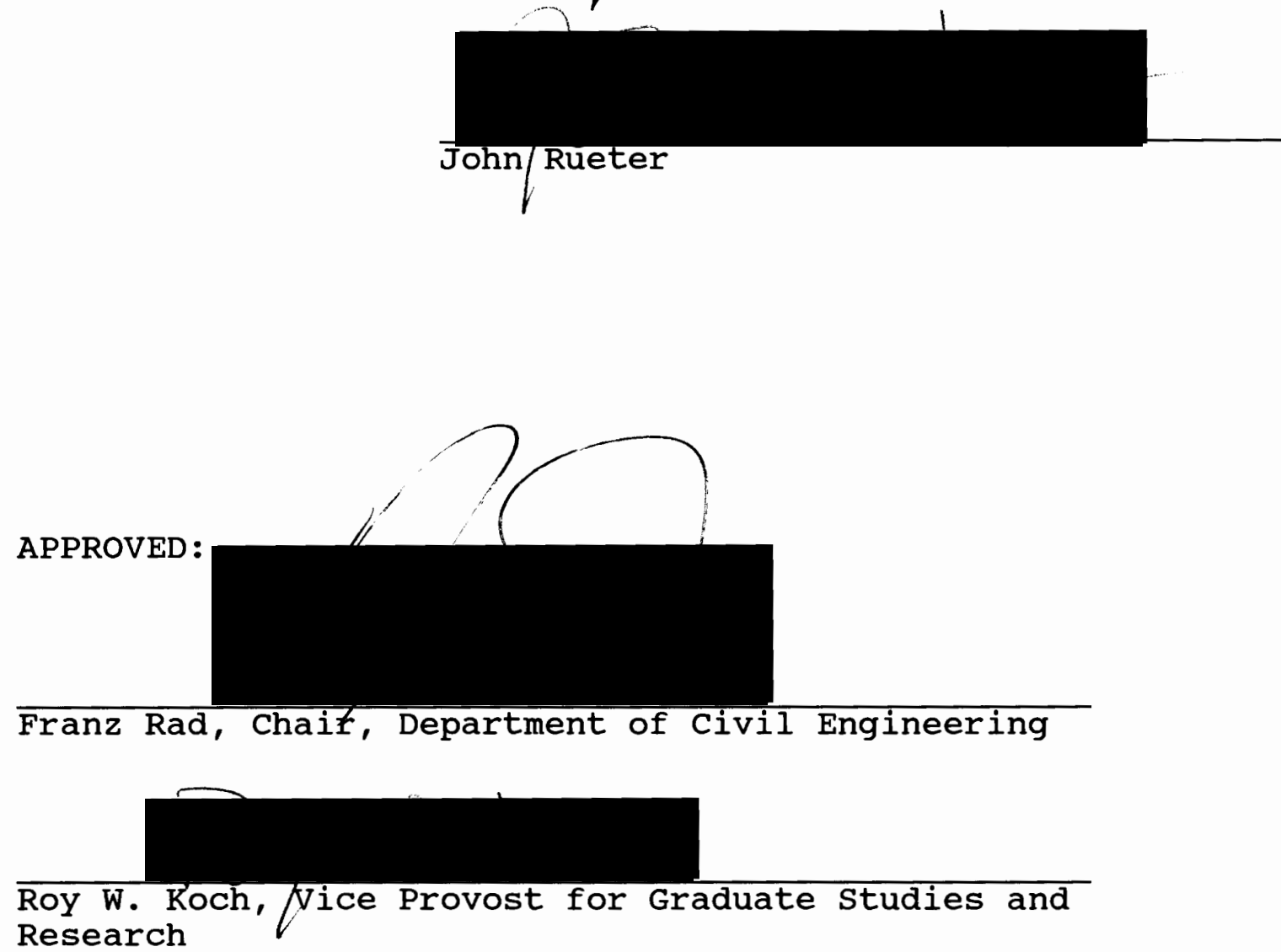


\section{ACKNOWLEDGEMENTS}

The research presented in this thesis represents a small portion of a research project granted to faculty at both Portland State University and oregon State University to study the Tualatin River Basin by the oregon Department of Environmental Quality. Much gratitude is owed to the D.E.Q. for their support in this project, without which I would not have been here. I would also like to thank Dr. Scott Wells for his support and helpfulness on this project and throughout my studies at P.S.U. I would also like to recognize the other people involved in this project at P.S.U., Dr. Roy Koch, Chris Berger, Fei Tang, and Patrick Moore. The diversity of this group led to some very interesting conversations which I will miss. I would especially like to thank Marsi for her continued support and for being my best friend throughout the struggles of graduate school. 
TABLE OF CONTENTS

PAGE

ACKNOWLEDGEMENTS. ....................... ii

LIST OF TABLES............................ vii

LIST OF FIGURES $\ldots \ldots \ldots \ldots \ldots \ldots \ldots \ldots \ldots \ldots \ldots \ldots \ldots \ldots \ldots \ldots$

CHAPTER

I INTRODUCTION.......................... 1

The Tualatin River Basin............... 1

Henry Hagg Lake................... 4

II LAKE AND RESERVOIR MODELING.............. 8

Definition of modeling............... 8

A Brief History of Lake and

Reservoir Modeling.................. 9

III THE CE-QUAL-W2 MODEL.................. 16

Introduction.................... 16

Model History

Model Capabilities

Model Limitations

Model Layout and Input Requirements

Model Theory..................... 20

Surface Heat Exchange

Hydrodynamics and Transport

Numerical Solution

IV HAGG LAKE MODEL SETUP................. 27

Hagg Lake Bathymetry............... 27

Hagg Lake Meteorological Data............ 31 
Hagg Lake Inflows and Outflows.......... 32

Other Input Files................. 35

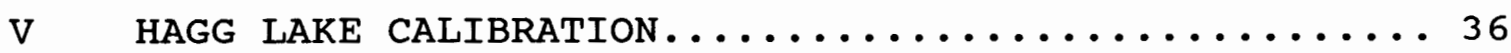

Introduction...................... 36

Hagg Lake Initial Conditions........... 36

Calibration of Hydraulics...............40

Calibration of water Quality

Constituents and Temperature............ 46

Hagg Lake Calibration Conclusions.......... 62

VI HAGG LAKE VERIFICATION................. 64

Introduction..................... 64

Verification of Hydraulics............. 65

Verification of water Quality...........66 66

Verification Conclusions............. 71

VII ADDITIONAL FLOW ALTERNATIVE.............. 72

Introduction.................... 72

Lake water Quality Violation Analysis....... 72

VIII RESERVOIR SEDIMENTATION ANALYSIS........... 85

Introduction................... 85

Particle Size Distribution

Addition to Hagg Lake Model............. 90

Observations of Sedimentation

at Hagg Lake....................... 96

A Simulation of Sediments in Hagg Lake....... 98

IX SUMMARY AND CONCLUSIONS.................. 106

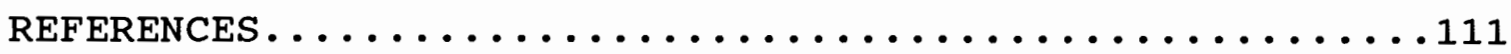




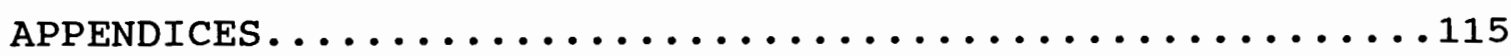

A WATER QUALITY CYCLES IN CE-QUAL-W2 ............. 115

B BATHYMETRY FOR HENRY HAGG LAKE.....................

C A DESCRIPTION OF FILES USED IN THE

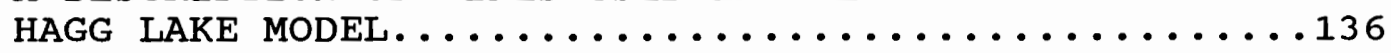

D PLOTS OF SEDIMENTATION PROCESSES IN HAGG LAKE......140 


\section{LIST OF TABLES}

TABLE

PAGE

I. Hagg Lake Calibrated Coefficient Values.........56

II. Water Quality Goals for Dissolved Oxygen, $\mathrm{pH}$, and Chlorophyll-a in Hagg Lake........... 73

III. Engineering Properties of Melbourne Silty Clay Loam......................... 91

IV. Particle Size Distribution of Peavine

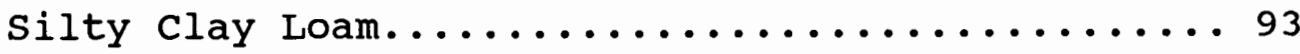

V. Particle Size Distribution of a Clayey-Kaolinitic-Mesix-Xeric-Haplohumult,

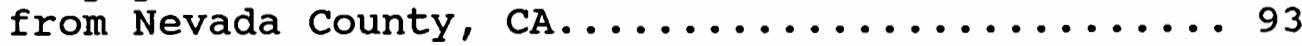

VI. Fraction of Clay Particles for the Hagg Lake Model........................ 94

VII. Fraction of silt Particles for the Hagg Lake Model......................... 94

VIII. Sediment Settling Rates for Hagg Lake.........96

IX. Inorganic Suspended Solids Concentrations Used for Inflow to Hagg Lake 1990....................... 99 
LIST OF FIGURES

FIGURE

PAGE

1. Tualatin River Basin................ 2

2. Tualatin River Daily Flowrate for 1991

at West Linn...................... 4

3. Three-Dimensional view of Henry Hagg Lake's bathymetry.......................6 6

4. CE-QUAL-W2 grid layout: $x=$ location of $\mathrm{U}, \mathrm{A}_{\mathrm{x}}, \mathrm{D}_{\mathrm{x}}$, and $\tau_{\mathrm{x}} ; \mathrm{O}=$ location of $\mathrm{W}, \mathrm{A}_{\mathrm{z}}$, and $\mathrm{D}_{z} ;+\stackrel{+}{+}=$ location of $\rho, \theta, P$, and $B . \ldots \ldots 26$

5. 2-dimensional plot of Hagg Lake created by SURFER for bathymetry estimation........ 29

6. Hagg Lake longitudinal cell delineation....... 29

7. CE-QUAL-W2 method for vertical cell

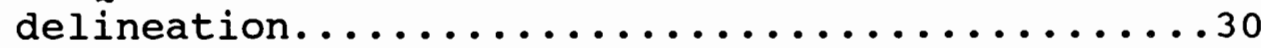

8. Volume versus Elevation curve for Henry

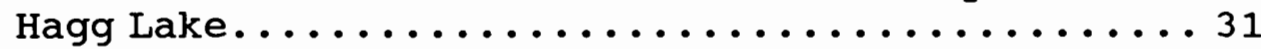

9. Summer initial temperature profile (May 1, 1990) used for Hagg Lake Calibration

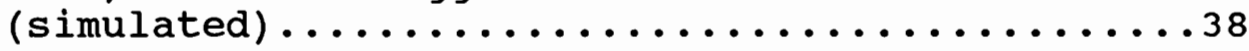

10. Summer initial conditions (May 1, 1990) used for dissolved oxygen profiles in Hagg Lake (simulated).

11. Total Hagg Lake inflows computed from "change in storage" data versus total Hagg Lake inflows computed by model for

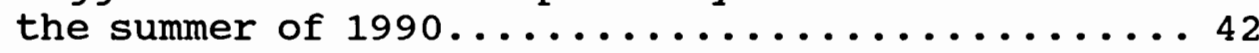

12. Hagg Lake outflow Intake Structure Plan view location................... 43

13. Hagg Lake Outflow Intake Structure Profile view......................44 
14. Hagg Lake water surface elevation predicted versus actual for the

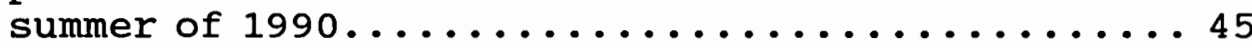

15. Hagg Lake calibration results for Chlorophyll-a, $\mathrm{PO}_{4}-\mathrm{P}, \mathrm{O}_{2}$, and Temperature for the summer of $1990 \ldots \ldots \ldots \ldots \ldots . \ldots . \ldots . \ldots 4$

16. Hagg Lake calibration results of $\mathrm{NH}_{3}-\mathrm{N}$, Detritus, $\mathrm{NO}_{3}-\mathrm{N}$, and Zooplankton for

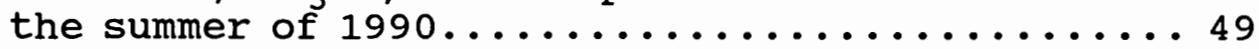

17. Hagg Lake calibration results for Inorganic Carbon, Alkalinity, $\mathrm{pH}$, and $\mathrm{CO}_{2}$, for the summer of $1990 \ldots \ldots \ldots \ldots . . \ldots$

18. Hagg Lake calibration results for TDS, TSS, and BOD for the summer of 1990...... 51

19. Hagg Lake calibration results for Bicarbonate, Carbonate, and profiles of Temperature and $\mathrm{O}_{2}$, for the summer

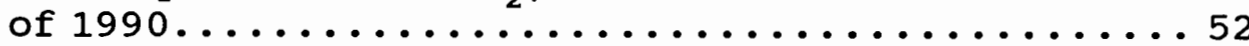

20. Hagg Lake calibration profiles of Chlorophyll-a, $\mathrm{PO}_{4}-\mathrm{P}, \mathrm{NH}_{3}-\mathrm{N}$, and $\mathrm{NO}_{3}-\mathrm{N}$ for the summer of $1990 \ldots \ldots \ldots \ldots . \ldots \ldots$

21. Water Surface Elevation simulation versus actual for verification year 1991........... 65

22. Verification of Chlorophyll-a, $\mathrm{O}_{2}, \mathrm{PO}_{4}-\mathrm{P}$, and Temperature, summer 1991.............. 67

23. Verification of $\mathrm{NH}_{3}-\mathrm{N}, \mathrm{NO}_{3}-\mathrm{N}$, Detritus, and zooplankton, for summer of 1991............ 68

24. Verification of TDS, TSS, BOD-U, and $\mathrm{pH}$

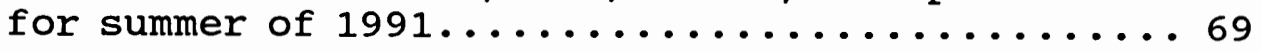

25. Base Case for Hagg Lake Dissolved Oxygen violations summer of 1990 (Average violation

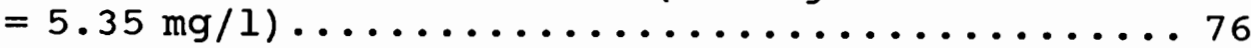

26. Dissolved Oxygen Violations with additional 100 cfs outflow from 6/15 through 9/15 1990 (Average violation $=5.12 \mathrm{mg} / \mathrm{l}) \ldots \ldots \ldots \ldots$

27. Base Case for Hagg Lake $\mathrm{pH}$ violations, for the summer of 1990 (Average violation $=8.65$ ) 
28. $\mathrm{pH}$ violations base case with $100 \mathrm{cfs}$ additional flow from $6 / 15$ through $9 / 15$ 1990 (Average violation $=8.65) \ldots \ldots \ldots \ldots \ldots 77$

29. Base Case for Hagg Lake Chlorophyll-a violations, for the summer of 1990 (Average violation $=40.15 \mu \mathrm{g} / 1$ ) $\ldots \ldots \ldots \ldots \ldots 78$

30. Chlorophyll-a violations base case with 100 cfs additional flow from $6 / 15$ through 9/15 1990 (Average violation = $40.65 \mu \mathrm{g} / 1) \ldots \ldots \ldots \ldots \ldots \ldots \ldots \ldots \ldots \ldots \ldots . \ldots . \ldots . \ldots$

31. Hagg Lake Outflow Temperature, Water Surface Elevation, $\mathrm{pH}$, and Chlorophyll-a concentration base case 1990 versus base case +100 cfs from $6 / 15$ through $9 / 151990 \ldots \ldots$. . 81

32. Hagg Lake Outflow Dissolved oxygen, Orthophosphorous, $\mathrm{NO}_{3}-\mathrm{N}$, and $\mathrm{NH}_{3}-\mathrm{N}$ Base Case 1990 versus Base Case +100 cfs additional flow from $6 / 15$ through $9 / 151990 \ldots \ldots \ldots \ldots . \ldots 83$

33. Hagg Lake site location for graphing suspended particle results................100

34. Concentrations of inorganic particles versus Julian day at longitudinal cell 14, vertical cell 9, 1990..................101

35. Sum of inorganics suspended solids versus Julian day at longitudinal cell 14, vertical cell $9,1990 \ldots \ldots \ldots \ldots \ldots \ldots \ldots \ldots \ldots \ldots$

36. Concentrations of inorganic suspended solids versus Julian day at longitudinal cell 22, vertical cell 9, 1990............102

37. Sum of inorganic suspended solids versus Julian day at longitudinal cell 22,

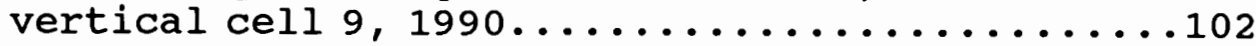

38. Concentrations of inorganic suspended solids versus Julian day at outlet intake

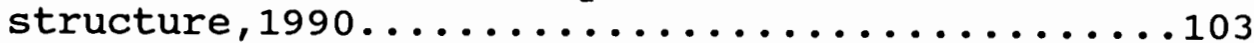

39. Sum of inorganic suspended solids versus Julian day at outlet intake structure, $1990 \ldots .103$ 
CHAPTER I

INTRODUCTION

THE TUALATIN RIVER BASIN

The Tualatin River is an 86 mile long river with a drainage basin of $711 \mathrm{mi}^{2}$ (Wolf, 1992). The river flows mainly in Washington County, oregon, eventually reaching the Willamette River (see Figure 1). Combinations of urban growth, increased agriculture, and low summer flows have caused the water quality in the Tualatin River to decline.

The Tualatin River Basin today is a complex mixture of agricultural, forestry, and urban land uses (Miner \& Scott, 1992). The Basin is located in the foothills of the relatively low oregon coast Range. Streamflows in the Tualatin Basin are dependent on rain events for there is no contribution from snowpack in this range during the summer. During the summer months, the Tualatin River base flow decreases considerably. The River has had flow rates of 2000 to $3500 \mathrm{cfs}$ in the winter months, but the natural flow during the summer has dropped below 46 cfs (U.S.A., 1991) (see Figure 2). The summer low flow condition causes the river to become a slow moving lake in its lower reaches. Henry Hagg Lake was built primarily to provide water to the Tualatin River Basin 
during the summer months for both irrigation demand and enhanced water quality (Otto, 1991).

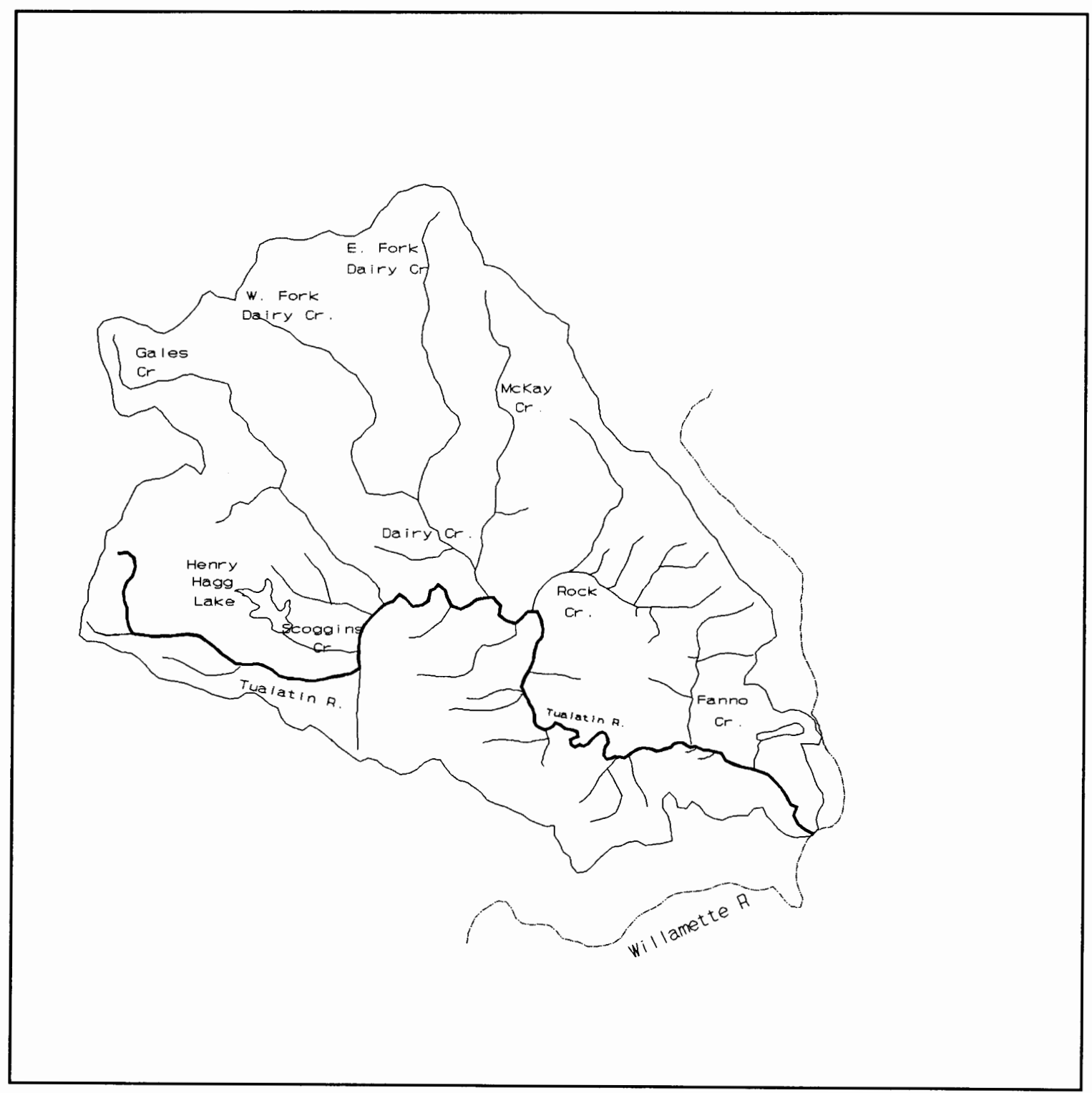

Figure 1. Tualatin River Basin.

The area of the Tualatin Basin was one of the earliest farming settlements in Oregon. Agriculture developed quickly in the basin because existing open areas made clearing the 
ground easy, and the soils of the basin were rich. As time went on, timbered tracts were cleared and more land came under cultivation (Johnson et. al., 1985). Hay, grain, and livestock production were the basis of the early economy and they are still an important part of the economy today. As population increased in the area, irrigation water and flood control demands increased, and the need for a new reservoir to supplement the summer low flow months and control floods during the wet winter became apparent (Johnson et. al., 1985) . During the 1960 's, the lower Willamette River was studied because of its poor water quality, and steps were taken to reduce waste loads to the river and enhance the water quality. A report on the Willamette River Basin was written in 1967 by the Federal water Pollution Control Administration which outlined the immediate needs of the willamette River to enhance its quality. The following excerpt concerning the Tualatin River was taken from this report (FWPCA, 1967, pg.8):

The Tualatin River's need for augmented summer flows is perhaps the most immediate and pressing in the Willamette River Basin. The watershed of the Tualatin already provides an average level of waste reduction that exceeds 90 percent, yet dissolved oxygen in the lower river consistently drops below the $5 \mathrm{mg} / \mathrm{l}$ required for fish passage; and other quality parameters present an equally dismal picture. Projections of population and industrial output indicate that by 1985 a flow of at least 260 cfs at and below Farmington will be required at all times if passage for fish runs is to be maintained. Development of advanced waste treatment and additional storage from reservoir sites being studied on other tributaries of the Tualatin will be required if nuisance conditions are to be averted in the future along this waterbody marked by rapid population growth. 
A storage reservoir, Henry Hagg Lake, was built to augment flows in the Tualatin, and the FWPCA's forecast was correct. Today scientists and engineers are looking for ways to improve the Tualatin's water quality.

TUALATIN RIVER AT WEST LINN JANUARY TO SEPTEMBER 1991

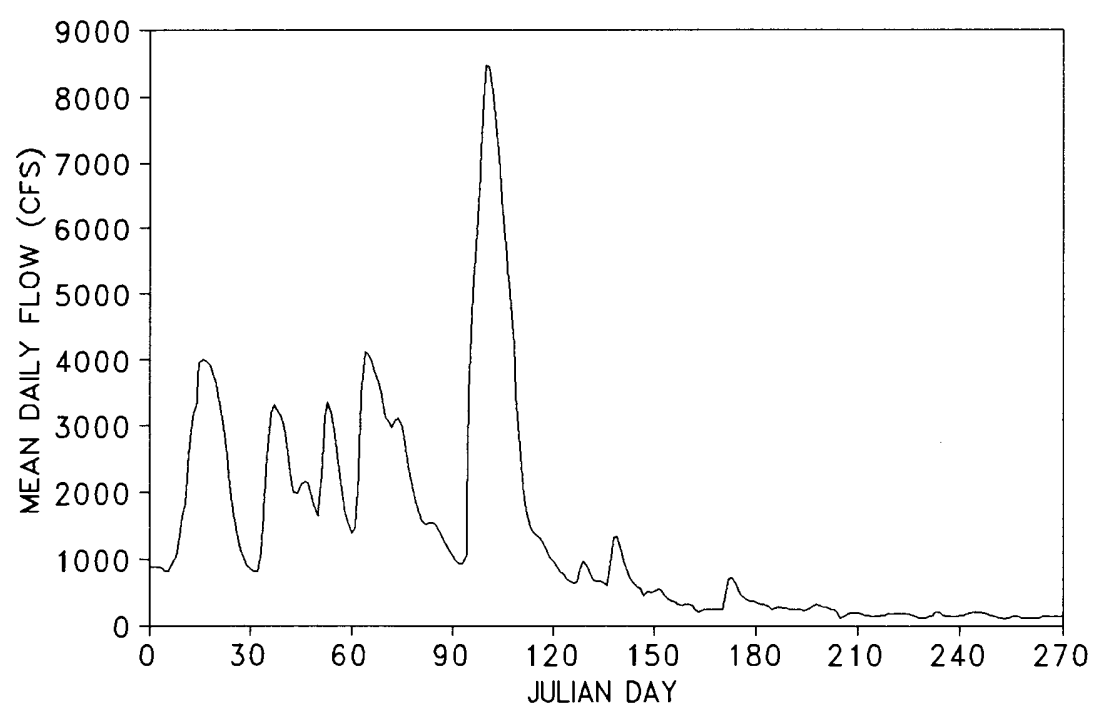

Figure 2. Tualatin River Daily Flowrate for 1991 at West Linn.

\section{HENRY HAGG LAKE}

Henry Hagg Lake is a "multi-purpose reservoir", built by the U.S. Bureau of Reclamation in 1972 and put into service in 1974. The reservoir is owned by the Bureau of Reclamation and operated by the Tualatin Valley Irrigation District (Washington County). The reservoir was named in honor of 
Henry Hagg, a prominent oregon dairyman and Washington County official who passed away in 1971 (Johnson et. al., 1985). Hagg Lake was formed by damming Scoggins Creek, a tributary on the upper end of the Tualatin River, near Forest Grove, oregon. Scoggins Dam is a 151 foot high earthfill structure (Johnson et. al., 1985).

The reservoir is used for many other purposes besides providing flow to the Tualatin River for enhanced water quality. The lake is used for flood control, municipal and industrial water demand, and recreation (Otto, 1991, Washington County, Johnson et. al., 1985). Boat launching and mooring facilities have been constructed, the lake is stocked annually with rainbow trout, and there are large day-use areas with picnic tables, shelters, and water facilities (Johnson et. al., 1985). The area around the lake is used for fishing, picnicking, water-skiing, boating, and bicycling.

During the late 1960 's, the Bureau of Reclamation did an operation study on the Tualatin River to see how much storage was necessary (FWPCA, 1967). The study used the 1944 water year (a dry year) to calculate the amount of storage required to maintain adequate flow in the Tualatin during the summer. The study found that 46,260 acre-feet of water storage were required, of which 10,400 acre-feet were required for water quality releases (FWPCA, 1967). Figure 3 shows the bathymetry of Henry Hagg Lake as it was constructed. 


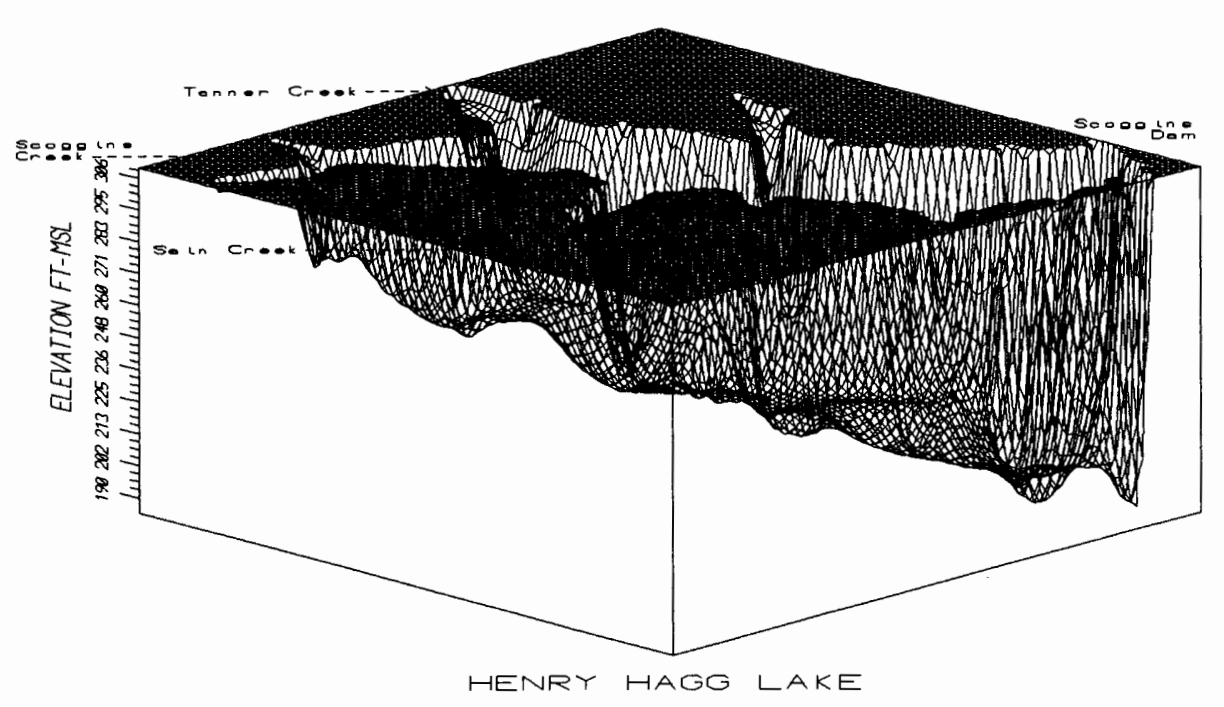

Figure 3. Three-Dimensional view of Henry Hagg Lake's bathymetry.

Hagg lake has a storage capacity of 59,910 acre-feet, where 53,640 acre-feet is active storage and 6,280 acre-feet is "dead storage" used for sedimentation (Otto, 1991). The top 20,300 acre-feet is used for flood control (ample to attenuate a 50-year flood), 14,000 acre-feet is stored for municipal and irrigation water supply, and 16,900 acre-feet is stored for water quality enhancement (Johnson et. al., 1985). The pool is drawn down during the dry summer months by an average of 22 feet (Johnson et. al., 1985) and filled again during the wet winter months. According to the Scoggins Dam operator, the reservoir is to be filled by May 1st at an 
elevation of 303.50 feet M.S.L. (Otto, 1991). Outflows are dictated by flood conditions, water purchase demands, and minimum requirements. The minimum outflow requirement is 10 cfs from December through september, and 20 cfs from October through November (Otto, 1991). At full pool (303.50 feet M.S.L.), the lake covers 1153 acres having a maximum depth of 110 feet and an average depth of 51 feet (Johnson et. al., 1985)

The drainage basin of Hagg Lake covers an area of 37.5 square miles located in the foothills of the oregon coast Range (Johnson et. al., 1985). The highest point in the basin is Saddle Mountain, at 3535 feet M.S.L., which is also the highest point in the northern portion of the oregon coast Range. Most of the area is forested with second-growth Douglas fir. The area is covered by thick soils of clay and silt overlying bedrock that is a mixture of sandstone and older volcanic rocks that typify this region (Johnson et. al., 1985)

A computational model of the hydrodynamics and water quality of Henry Hagg Lake was created in order to model its relationship with the Tualatin River. This model was used to show the effects on Hagg Lake if additional flow to the Tualatin during the summer season were allowed. The model was also used to look at turbidity and sedimentation cycles in Hagg Lake. 
CHAPTER II

LAKE AND RESERVOIR MODELING

\section{DEFINITION OF MODELING}

In the introduction of the book "Principles of Surface Water Quality Modeling and Control", Thomann and Mueller (1987) define a mathematical model as follows:

A theoretical construct, together with assignment of numerical values to model parameters, incorporating some prior observations drawn from field and laboratory data, and relating external inputs or forcing functions to system variable responses.

Models are often created for water bodies so that water quality changes to a water body can be predicted based on changes in forcing conditions. Also, structural and nonstructural changes to a water body can be simulated to look at their potential effects before such changes are made. Engineers have used and continue to use models for design and planning of most projects, whether they are building a new skyscraper, designing the space shuttle, or constructing a heart valve. Modeling has become an important part of engineering, and with the increased demand placed on our natural environment, modeling of water bodies was a natural step in engineering them for our future. 
with advances in science, mathematics, and computer technology, full scale mathematical models have been refined to simulate chemical processes, biological productivity, and hydrodynamic processes in reservoirs and lakes. This chapter reviews some of the history of lake and reservoir modeling, leading to models used today. The chapter is a synopsis of literature found on lake modeling and represents a small portion of a vast amount of research performed by others.

\section{A BRIEF HISTORY OF LAKE AND RESERVOIR MODELING}

Mathematical modeling of water bodies began in the early 1900's (Orlob, 1983), when it became apparent that man's pollution problems could not be solved by mother nature alone. The first known mathematical model for a water body was the Streeter-Phelps Equation describing the balance of dissolved oxygen in a stream (Orlob, 1983):

The governing equation has the form:

$$
\frac{d O_{2}}{d t}-Q \frac{d O_{2}}{d V}=k_{a}\left(O_{2_{s}}-O_{2}\right)-k(L)
$$

and the steady-state solution is:

$$
D_{O_{2}}=\frac{k L_{i}}{k_{a}-k}\left(e^{-k \theta_{H}}-e^{-k_{a} \theta_{H}}\right)+D_{i} e^{-k_{a} \theta_{H}}
$$

where:

$$
\begin{array}{ll}
\mathrm{O}_{2}= & \text { Dissolved oxygen concentration } \\
\mathrm{V}= & \text { Control volume } \\
\mathrm{Q}= & \text { Volumetric Flowrate } \\
\mathrm{k} & =\text { BOD decay rate } \\
\mathrm{k}_{\mathrm{a}}= & \text { reaeration coefficient } \\
\mathrm{O}_{2 \mathrm{~s}}= & \text { Dissolved oxygen saturation } \\
& \text { concentration } \\
\mathrm{L}= & \text { BOD concentration } \\
\mathrm{D}_{\mathrm{O} 2}= & \text { Dissolved oxygen deficit }\left(\mathrm{O}_{\mathrm{s}}-\mathrm{O}\right)
\end{array}
$$




$$
\theta_{\mathrm{H}} \quad=\text { Residence time }(\mathrm{V} / \mathrm{Q})
$$

This relatively simple equation was developed in the 1920's when the Ohio River Commission began a study of the effects of pollution on domestic water supply (streeter and Phelps, 1925).

During these early stages of modeling, full scale mathematical models of water bodies such as lakes and reservoirs were impractical since computers and even calculators were not available. In the late 1950's, with the advent of the computer, mathematicians developed techniques for solving large sets of simultaneous algebraic equations and differential equations using finite difference approximations (Orlob, 1983). This new technology opened doors for mathematical modeling of water bodies.

The first lake models created were concerned with modeling thermal stratification (Orlob, 1983, James, 1984, orlob, 1981). In the mid 1960's attention brought about by environmentalists was directed toward water quality problems associated with the installation of surface water impoundments (Orlob, 1981). These first mathematical models of reservoirs were used by engineers modeling temperature stratification in reservoirs and limnologists predicting eutrophication in lakes (Orlob, 1983, James, 1984, Orlob, 1981). These models were one-dimensional and did not incorporate hydrodynamics. They modeled the thermal regime of systems well (i.e., deepstratified lakes), but were inadequate for all systems, 
especially those with relatively large inflow to size ratios (Orlob, 1981).

The next advancement in lake modeling was the addition of water quality constituent cycles to the already developed onedimensional thermal stratification models (Orlob, 1981). This addition was accomplished by applying the advection-diffusion equation to each process (i.e., dissolved oxygen - BOD relationship). The advection-diffusion equation is a mass balance equation performed on a particular constituent of interest. The equation remains the same for each process with the exception of the source-sink term. The other terms (i.e., advection and diffusion) are a function of the fluid. The chemical and biological interactions are lumped into the source-sink term. The equation has the form:

$$
\frac{\partial V C}{\partial t}+Q \frac{\partial C}{\partial X}=V D \frac{\partial^{2} C}{\partial X^{2}} \pm S / S
$$

where:

$$
\begin{aligned}
& C=\text { Constituent of interest } \\
& \mathrm{Q}=\text { Volumetric Flow } \\
& \mathrm{V}=\text { Control Volume } \\
& \mathrm{X}=\text { One-Dimensional direction } \\
& \mathrm{D}=\text { Coefficient of diffusion } \\
& \mathrm{S} / \mathrm{S}=\text { Sources and Sinks }
\end{aligned}
$$

The most significant problem with these first models was their inability to model systems where hydraulics played an important role (Orlob, 1981). Therefore, the next step in the history of modeling lakes was to add more dimensions to the 
models. With the addition of more dimensions, Navier-stokes equations for the conservation of momentum combined with Reynold's turbulent transport concepts were added to the models to improve the prediction of the hydrodynamics of lakes (Orlob, 1983).

The equation below represents the Turbulent Momentum Equation for the $\mathrm{x}$-direction:

$$
\frac{\partial \bar{u}}{\partial t}+\frac{\partial \overline{u u}}{\partial x}+\frac{\partial \overline{u v}}{\partial y}+\frac{\partial \overline{u w}}{\partial z}-\Gamma \bar{v}=-\frac{1}{\rho} \frac{\partial \bar{p}}{\partial x}+v \nabla^{2} \bar{u}-\frac{\partial u_{u}^{\prime}}{\partial x}-\frac{\partial \dot{u}^{\prime}}{\partial y}-\frac{\partial u^{\prime} \underline{w}}{\partial z}
$$

Where:

$$
\begin{array}{ll}
t & =\text { time } \\
\mathbf{x}, \mathrm{y}, \mathrm{z} & =3 \text {-dimensional coordinates } \\
\mathrm{u}, \mathrm{v}, \mathrm{w} & =\text { mean velocities in the } \mathrm{x}, \mathrm{y}, \text { and } \mathrm{z}- \\
& \text { directions } \\
\mathrm{u}^{-} \mathrm{v}^{-} \mathrm{w}^{-} & =\quad \text { time-averaged turbulent eddy } \\
\mathrm{g} & \quad \text { transport of momentum } \\
\rho & =\text { gravitational acceleration constant } \\
\mathrm{p} & =\text { pressure } \\
\Gamma & =\text { Coriolis parameter } \\
\mathrm{v} & =\text { kinematic viscosity }
\end{array}
$$

Similar equations exist for the $\mathrm{Y}$ and $\mathrm{Z}$ momentum equations. The U.S. Army Corps of Engineers were one of the first groups to develop multi-demensional water quality models. In the early 1970's the Corps of Engineers were trying to predict temperature effects of impoundments placed in the columbia River Drainage, and their resulting effects on anadromous fish populations (Orlob, 1981). These impoundments were designed for hydroelectric power generation, not water storage. Thus, the prior one-dimensional thermal stratification models were 
unable to predict the temperature regime of these impoundments adequately, and the corp developed a two-dimensional water quality and hydrodynamic model for stratified flow systems. They successfully applied this model to the Lower Granite Project on the Snake River in the early 1970's (Orlob, 1981). With the development of higher-order models of lakes came an enormous increase in computational needs. The computational needs of these higher-order models increased exponentially. Both finite element and finite difference numerical techniques are used to solve the numerous equations associated with these higher-order models. Therefore, in the early days of lake modeling, only large institutions with mainframe computers were able to use these models, and even then modeling simulations would take enormous computational time.

The most significant, next advance in lake modeling came from advances in computer technology. What once took large institutions with mainframe computers to accomplish could now be performed on advanced personal computers by any individual with a good understanding of modeling in less time. This led to the proliferation of many new models. However, most of these models were poorly documented, limiting their use to their creators (Orlob, 1981). Also, computer advancements have led to the use of many models by people without the proper training or experience, who view a model as a "blackbox". 
With all the advancements made in modeling, the use of sophisticated models still lies in research institutions, whereas in practice, the simpler one-dimensional models are used. In the literature on modeling, the term "technology transfer" is often seen. This term refers to the need for the high technology possessed at research institutions to be used in more practical situations in the "real" world. As Gerald orlob put it in the preface of his book on water quality modeling (1983):

....despite the enthusiasm with which modeling of aquatic systems has apparently been embraced, there exists a gap between conception of the model as an exercise of the mind and its use as a practical tool. One only has to examine the literature to see that comparatively few water quality models have attained the status that enables the technology they represent to be transferred to others.

During the past decade, modelers have been researching better ways to represent water quality cycles and hydrodynamics which are simpler and rely less on empirical formulations. They have also tried to address the need for "technology transfer", and more models have been adapted for use as tools in science and engineering practice.

This thesis represents the application of CE-QUAL-W2 (Corps of Engineers, 1986), a model which could be considered "the state of the art", to Hagg Lake. The Hagg Lake Model is a sub-model of a complete model of the Tualatin River system, which has been created as a working tool for use by scientists 
and engineers evaluating the Tualatin River system. The adaptation of a multi-dimensional model is a very complicated and time consuming task. The adaptation of CE-QUAL-W2 to Hagg Lake took about a year. 
CHAPTER III

THE CE-QUAL-W2 MODEL

\section{INTRODUCTION}

This chapter is a review of the CE-QUAL-W2 model, its application, history, capabilities, limitations, options, and theory. The majority of the chapter represents a synopsis of the more detailed users manual (Corps of Engineers, 1990).

CE-QUAL-W2 is a two-dimensional, laterally averaged, dynamic model of hydrodynamics and water quality. The model can be applied to: rivers, lakes, reservoirs, and estuaries. The model was chosen for use in the modeling of Hagg Lake for the following reasons: (i) modeling of water quality in twodimensions could be accomplished, showing both longitudinal and vertical transport, (ii) over 20 water quality parameters could be modeled, (iii) the FORTRAN code could be modified, and (iv) hydrodynamic mixing would be modeled more accurately than with a one-dimensional model.

\section{Model History}

The CE-QUAL-W2 code has been in development since 1975. It began as a laterally averaged reservoir model (LARM) (Edinger and Buchak, 1975). Subsequent modifications to handle multiple branches and tidal boundary conditions 
produced the "Generalized Longitudinal-Vertical Hydrodynamics and Transport Model" (GLVHT). Next, water quality algorithms were added to the model, and CE-QUAL-W2 was born. Additional modifications over the years to increase model efficiency, stability, and to make the model easier to use have improved the CE-QUAL-W2 model. The model is still in a development stage, and even during the modeling of Hagg Lake, changes in the source code and input files were performed on the continuously updated model.

\section{Model Capabilities}

The CE-QUAL-W2 model is able to predict the hydrodynamics of a water body including: water surface elevations, vertical velocities, and horizontal velocities. The model includes its temperature calculations with hydrodynamics because of effects on water density. This allows one to model temperature and hydrodynamics independent of water quality. The CE-QUAL-W2 code has the ability to model up to 20 water quality constituents, including a conservative tracer, coliform bacteria, inorganic suspended solids, total dissolved solids, labile organic matter, refractory organic matter, an algal group, detritus, ortho-phosphorus, ammonia, nitrate-nitrite, dissolved oxygen, iron, sediment, alkalinity, carbon-dioxide, inorganic carbon, $\mathrm{pH}$, bicarbonate, and carbonate. Since the code is so versatile, other water quality parameter additions have been included: zooplankton, CBOD, and 5 additional inorganic suspended solid size fractions (See Chapter VIII) 
have been added to the Hagg Lake model.

The model can handle multiple point source and non-point source inflows in the forms of tributaries and distributed tributaries. The model can also be used in many situations such as complex river systems, dendritic reservoirs, and estuaries because it has the capability to simulate ice cover, variable head boundaries, and multi-branched water bodies. The model can be run efficiently for large time periods, because it has an "autostepping" timestep algorithm which allows the user to vary the timestep during a given simulation. The model has many other capabilities which make it efficient, details of which can be found in the corps of Engineers (1986a) and the Corps of Engineers (1990).

\section{Model Limitations}

Since the model is two-dimensional, governing equations are laterally averaged. Governing equations are also layer averaged, however, layers can have variable sizes. Water quality biological sources and sinks are inherently simplified descriptions of a much more complex aquatic ecosystem (see Appendix A). The model includes only one algal compartment. Macrophytes are not included in water quality calculations. The model uses the "QUICK" quadratic upstream differencing algorithm (Leonard, 1979) as its method to solve partial differential equations, and this method can introduce numerical diffusion, which can have a higher magnitude than actual physical diffusion. Also, truncation errors in solving 
finite-differences can be important as the timestep and spacing are increased. High water surface slopes can cause numerical instability, however, in the Hagg Lake model this was not encountered.

\section{Model Layout and Input Requirements}

The first step in modeling a water body with the CE-QUALW2 model is to set up the computational grid. The geometry of a water body is input to the CE-QUAL-W2 model through three parameters: the longitudinal spacing, the vertical spacing, and the average cross-sectional width. The longitudinal spacing is determined by breaking the water body into longitudinal cells, parallel to one another and perpendicular to the centerline of horizontal flow. The vertical spacing is determined in the same manner, except these cells go from the water surface to the bottom boundary of the water body. By interpreting cross-sectional data from the water body, average cross-sectional widths are determined for each vertical cell. One must evaluate a number of factors when determining the longitudinal and vertical spacing of a waterbody, including: computational time, bottom slope, surface slope, and areas of strongest gradients. There are two types of cells in the CEQUAL-W2 model: active cells and boundary cells. Boundary cells are placed at the top of the uppermost active cell, the bottom of the lowest active cell, at the upstream side of the first active longitudinal cell, and at the downstream side of the last active longitudinal cell. These boundary cells have 
zero widths, and are used for boundary conditions in solution to the finite difference equations.

The main input file for running the CE-QUAL-W2 model is the control file. This file contains initial conditions for the model simulation including the simulation time period, surface layer location, temperature and constituent concentrations, location of all inflows, outflows, and withdrawals, coefficients for modeling water quality kinetics, and hydrodynamic parameters. The control file also tells the program where it can find necessary inflow, outflow, and geometric data (i.e., file names).

\section{MODEL THEORY}

\section{Surface Heat Exchange}

The CE-QUAL-W2 model uses either equilibrium temperatures for calculating surface heat exchange (Brady and Edinger, 1975) or a "term-by-term" surface heat flux calculation (Corps of Engineers, 1990). For the Hagg Lake simulation, the "termby-term" algorithm of the surface heat flux was used. A meteorological file was created for a model simulation containing average air temperature, average dew point temperature, cloud cover, wind speed, and wind direction on a daily basis. Other meteorological factors including latitude, solar radiation absorption coefficients, and gas exchange coefficients are input in the control file. In the term-byterm surface heat exchange analysis, the model calculates the 
net solar radiation from the time of day, the latitude, and the cloud cover for every time step. Other terms in the heat balance are calculated every time step from input values and calculated water surface temperatures.

\section{Hydrodynamics and Transport}

Transport and hydrodynamics are calculated in CE-QUAL-W2 from six equations with six unknowns. The equations were derived from laterally averaging the three-dimensional equations of fluid motion (Edinger and Buchak, 1975). The equations along with their descriptions are as follows:

Horizontal Momentum

$$
\frac{\partial U B}{\partial t}+\frac{\partial U U B}{\partial x}+\frac{\partial W U B}{\partial z}=-\frac{1}{\rho} \frac{\partial B P}{\partial x}+\frac{\partial\left(B A_{x} \frac{\partial U}{\partial x}\right)}{\partial x}+\frac{\partial B \tau_{x}}{\partial z}
$$

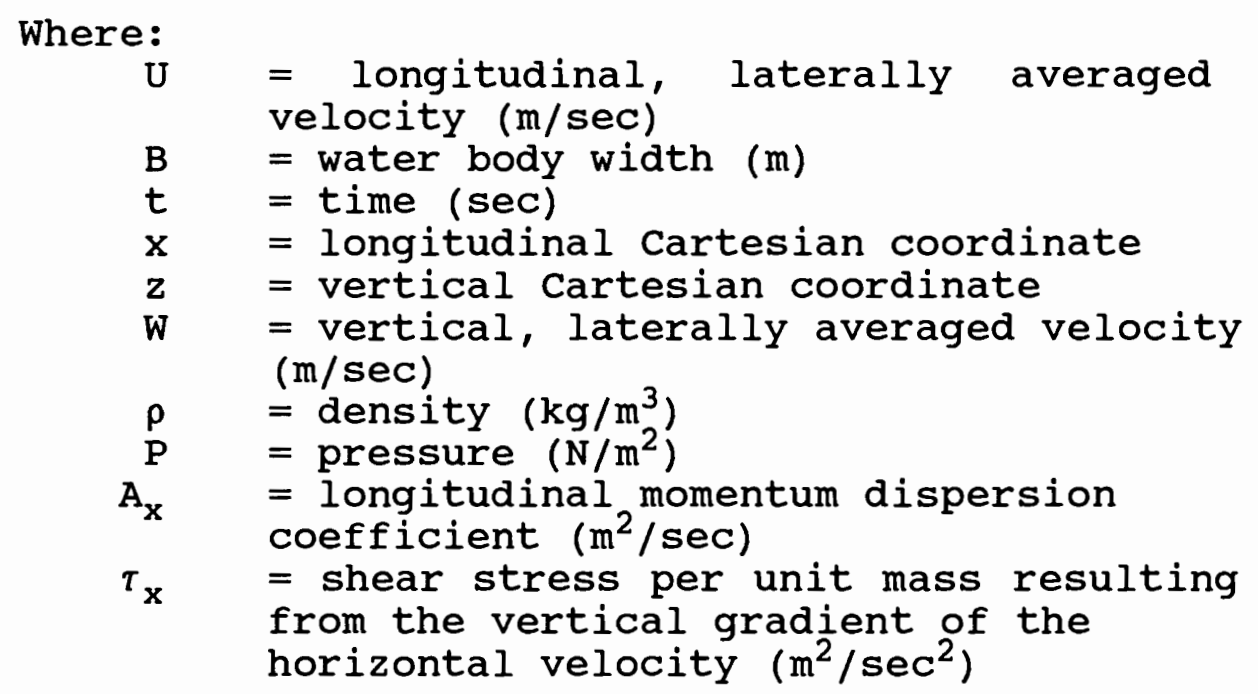

The first term is the time rate of change of horizontal 
momentum, while the second and third terms represent the horizontal and vertical advection of momentum. The first term on the right-hand-side is the pressure force from the horizontal pressure gradient, the second term is the horizontal dispersion of momentum, and the third term represents forces due to shear stress. Turbulence is modeled by eddy coefficients.

\section{Constituent Transport}

$$
\frac{\partial B \theta}{\partial t}+\frac{\partial U B \theta}{\partial x}+\frac{\partial W B \theta}{\partial z}-\frac{\partial\left(B D_{x} \frac{\partial \theta}{\partial x}\right)}{\partial x}-\frac{\partial\left(B D_{z} \frac{\partial \theta}{\partial z}\right)}{\partial z}=q_{\theta} B+S_{k} B
$$

Where:

$$
\begin{aligned}
\theta= & \begin{array}{c}
\text { laterally averaged constituent } \\
\text { concentration (mg/l) }
\end{array} \\
\mathrm{D}_{\mathrm{x}}= & \begin{array}{l}
\text { longitudinal temperature and constituent } \\
\text { dispersion coefficient }\left(\mathrm{m}^{2} / \mathrm{sec}\right)
\end{array} \\
\mathrm{D}_{\mathrm{z}}= & \text { vertical temperature and constituent } \\
& \text { dispersion coefficient }\left(\mathrm{m}^{2} / \mathrm{sec}\right) \\
\mathrm{q}_{\theta}= & \text { lateral inflow or outflow mass flow rate } \\
& \text { of constituent per unit volume } \\
& \begin{array}{l}
\text { (mg/l/sec) } \\
\mathrm{kinetics} \text { source/sink term for }
\end{array} \\
\mathrm{s}_{\mathrm{k}}= & \text { constituent concentrations (mg/l/sec) }
\end{aligned}
$$

The first term in this equation represents the time rate of change of constituent concentration, and the second and third terms are the horizontal and vertical advection of constituents. The fourth and fifth terms are the horizontal and vertical diffusion of constituents. The first term on the right-hand-side represents lateral inflows or outflows of constituents, and the last term represents all kinetic sources 
and sinks of constituents. Details of kinetic sources and sinks for each parameter may be found in Appendix A.

Free Water Surface Elevation

$$
\frac{\partial B_{w} W}{\partial t}=\frac{\partial}{\partial x} \int_{W}^{h} U B d z-\int_{W}^{h} q B d z
$$

Where:

$$
\begin{aligned}
B_{w} & =\text { time and spatially varying surface width } \\
& (\mathrm{m}) \\
\mathrm{w} & =\text { free water surface location }(\mathrm{m}) \\
\mathrm{h} & \text { total depth (m) } \\
\mathrm{q}= & \text { lateral boundary inflow or outflow } \\
& \left(\mathrm{m}^{3} / \mathrm{sec}\right)
\end{aligned}
$$

Hydrostatic Pressure

$$
\frac{\partial P}{\partial z}=\rho g
$$

Where:

$$
\begin{aligned}
& \mathrm{P} \quad \text { pressure }\left(\mathrm{N} / \mathrm{m}^{2}\right) \\
& \rho \quad=\text { fluid density }\left(\mathrm{kg} / \mathrm{m}^{3}\right) \\
& g \quad=\text { gravitational acceleration }\left(\mathrm{m} / \mathrm{sec}^{2}\right)
\end{aligned}
$$

This hydrostatic pressure equation is the vertical momentum equation with the elimination of all acceleration terms. Vertical velocities tend to be low and vertical accelerations tend to be very low compared to pressure differences, therefore, these terms are insignificant. 
Continuity

$$
\frac{\partial U B}{\partial x}+\frac{\partial W B}{\partial Z}=q B
$$

Where:

$$
\begin{aligned}
& q= \text { boundary inflow or outflow }(-) \text { per unit } \\
& \text { volume per second }\left(\sec ^{-1}\right)
\end{aligned}
$$

Equation of State

$$
\rho=f(\theta)
$$

Where:

$$
\begin{aligned}
& f(\theta)= \text { function for density of fluid which is } \\
& \text { dependent upon temperature, total } \\
& \text { dissolved solids, salinity, and } \\
& \text { suspended solids }
\end{aligned}
$$

\section{Computation of Hydrodynamics and Transport}

Six unknowns result from these six equations:

1. free water surface elevation, w

2. pressure, $P$

3. horizontal velocity, U

4. vertical velocity, $W$

5. constituent concentration, $\Theta$

6. density, $\rho$

The solution of these six equations for these six unknowns forms the basic structure of the CE-QUAL-W2 model. The reduction of these equations to two coordinates is the main feature that reduces computational time and storage over the three-dimensional case. Lateral averaging eliminates the lateral momentum balance, the lateral velocity component, and 
the coriolis acceleration term in the momentum equation.

\section{Numerical Solution}

The partial differential equations for the water surface elevation are solved using an implicit, space-staggered, finite difference solution algorithm. The "QUICK" (Leonard, 1979) solution algorithm is used for solution of the temperature and constituent equations using a Crank-Nicolson implicit algorithm. The grid is referred to as spacestaggered because some variables are defined at one location and the remainder are displaced by $\Delta x / 2$ or $\Delta z / 2$. Variables defined at the boundary of cells include the velocities $(U, W)$, the dispersion coefficients $\left(A_{x}, D_{x}, A_{z}\right.$, and $\left.D_{z}\right)$, and the internal shear stress $\left(\tau_{x}\right)$. The density $(\rho)$, the pressure (P), the average cross-sectional width (B), and all constituent concentrations and temperature $(\theta)$ are defined at the center of each cell. Figure 4 shows how CE-QUAL-W2 interprets these coefficients. 
Schematic of CE-QUAL-W2 Grid Layout

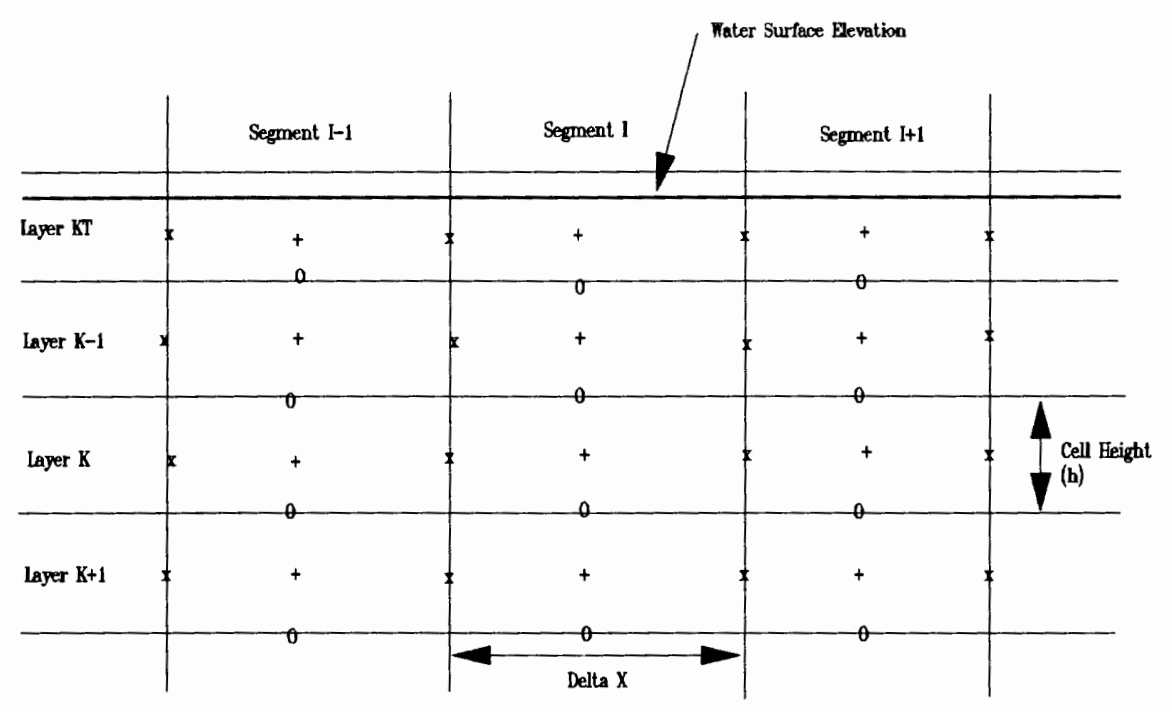

Figure 4. CE-QUAL-W2 grid layout: $x=$ location of $\mathrm{U}, \mathrm{A}_{\mathrm{x}}, \mathrm{D}_{\mathrm{x}}$, and $\tau_{\mathrm{x}} ; 0=$ location of $\mathrm{W}, \mathrm{A}_{\mathrm{z}}$, and $\mathrm{D}_{\mathrm{z}} ;+$ $=$ location of $\rho, \theta, P$, and $B$.

Each variable is a function of its spatial location $(I, K)$ and its time (n). The solution proceeds as follows: knowing the water surface elevations and velocity field at time $n$, the water surface elevations are solved for at time $n+1$. Using these updated surface elevations, horizontal velocities are solved for at time $n+1$. Vertical velocities are then solved for at time $n+1$ from the continuity equation. The new constituent concentrations are then computed from the constituent balance. These computations are then continued for the next time step. 
CHAPTER IV

HAGG LAKE MODEL SETUP

\section{HAGG LAKE BATHYMETRY}

Creating the CE-QUAL-W2 model of Hagg Lake consisted of creating the necessary input files listed in Appendix $C$. This chapter is intended to show how the input files were set up. The first step in creating the CE-QUAL-W2 model of Hagg Lake was generating the bathymetry file for the lake. The main source of data came from a highly detailed topographic map of the Hagg Lake area created by the U.S. Bureau of Reclamation before construction of Scoggins Dam. The map was digitized using the major topographic lines outlining the lake with AUTOCAD. A "dxf" file from AUTOCAD was sorted into an ASCII file with three columns for the $x, y$, and $z$ coordinates of each point digitized. The ASCII file was used with a software package called SURFER which created interpolated twodimensional and three-dimensional plots of the lake. Using the two-dimensional plot (See Figure 5), the lake was broken into longitudinal cells that were each 550 feet $(167.64 \mathrm{~m})$ in length. A 5 foot $(1.52 \mathrm{~m})$ spacing was chosen for vertical cells based on memory requirements and modeling accuracy. Hagg Lake was then divided into 31 longitudinal cells (including 2 inactive cells on either end) and 26 vertical 
cells (including 2 inactive cells one at the top and one at the bottom). By drawing a line through the center of each longitudinal cell and picking off two points, one at either side of the lake, a blanking file was created for use with SURFER. A blanking file for SURFER allows one to determine the elevations along any delineated line by the placement of two points in the blanking file. Using the SLICE utility within SURFER and the blanking file, cross-sections for each longitudinal cell were determined. A sorting program then Converted the SURFER file into the proper format for CE-QUALW2. This file was then checked for errors and verified. Figures 6 and 7 show how longitudinal and vertical cells were delineated for the Hagg Lake Model. To keep grid errors low, cell widths between neighboring cells were kept within a factor of 4 . 


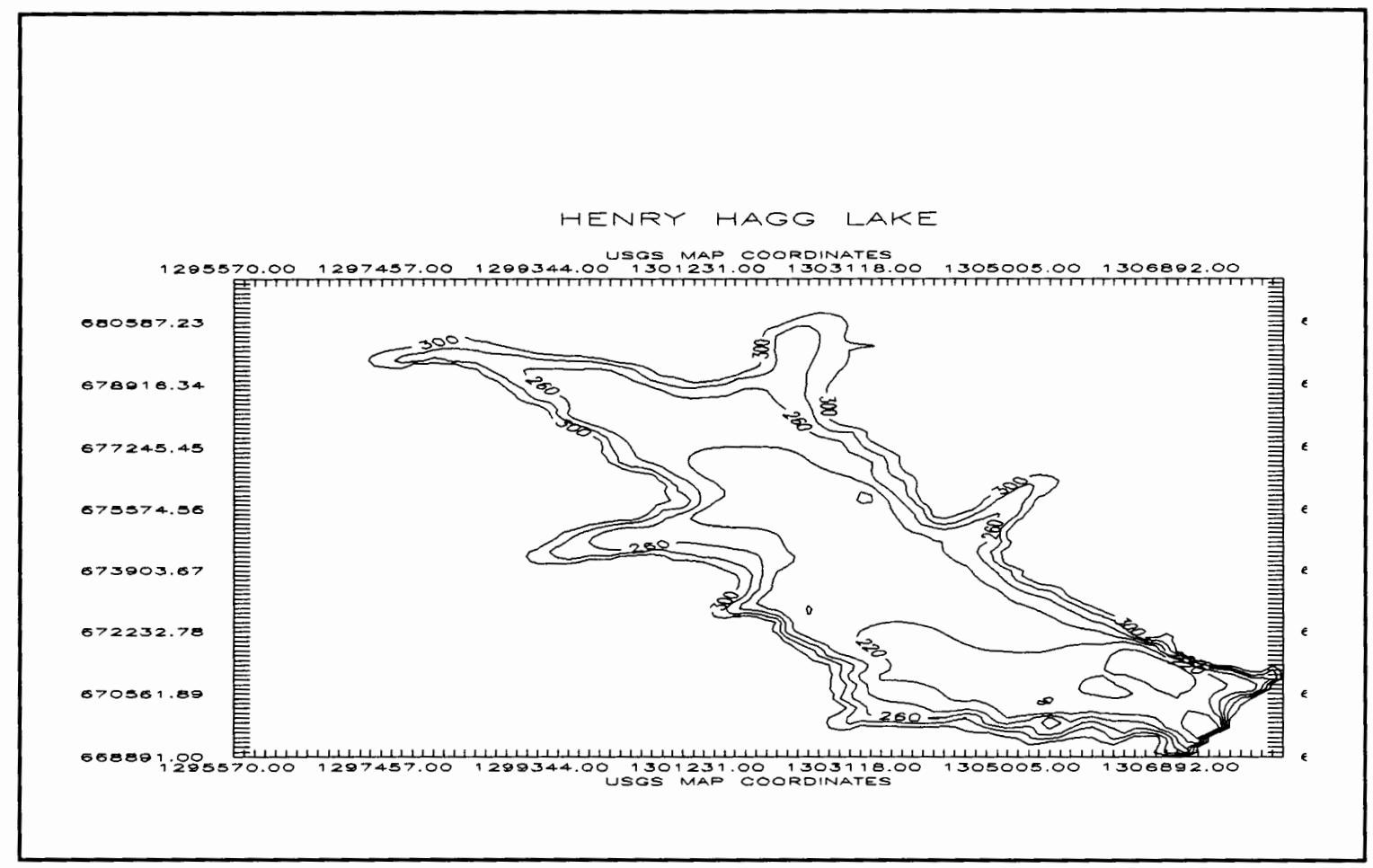

Figure 5. 2-dimensional plot of Hagg Lake created by SURFER for bathymetry estimation.

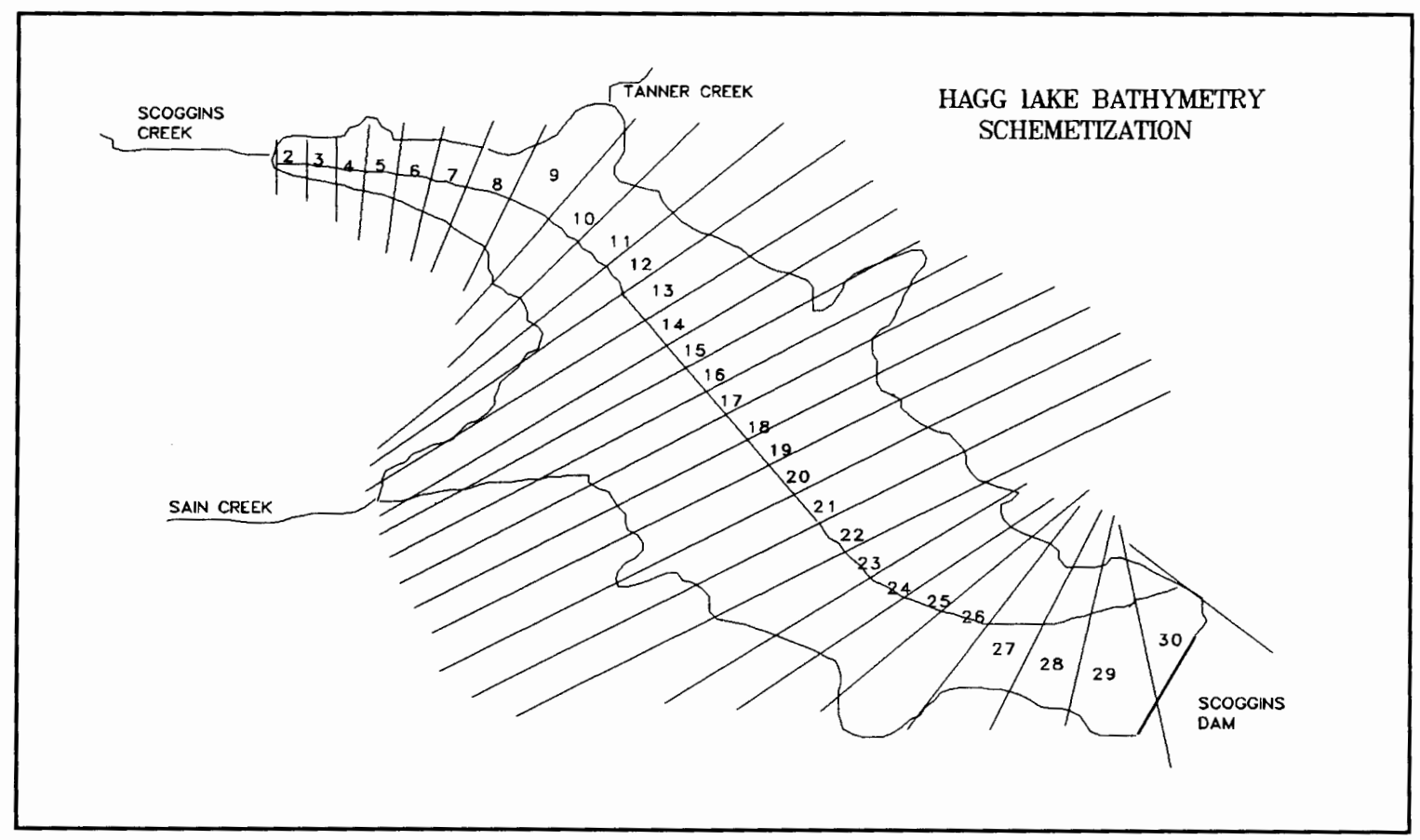

Figure 6. Hagg Lake longitudinal cell delineation. 
Schematic For CE-QUAL-W2 Vertical Cell Layout For Each Cross-Section

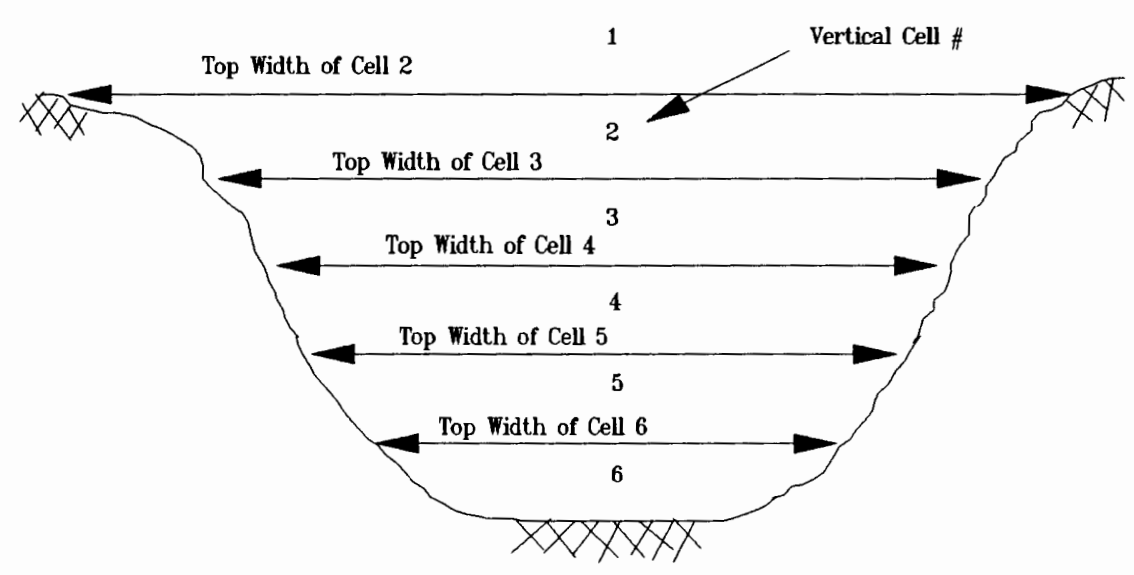

( There Are 26 Cells in the Hagg Lake Model )

Figure 7. CE-QUAL-W2 method for vertical cell delineation.

As mentioned before, Hagg Lake has an approximate capacity of 59,910 acre-feet for water storage. The bathymetry delineation of Hagg Lake was checked by creating a volume versus elevation curve. Using SURFER, volumes were calculated for elevations of the lake at 5 foot intervals. The volume of Hagg Lake vs. elevation is shown in Figure 8 . 
HAGG LAKE

VOLUME VS. ELEVATION

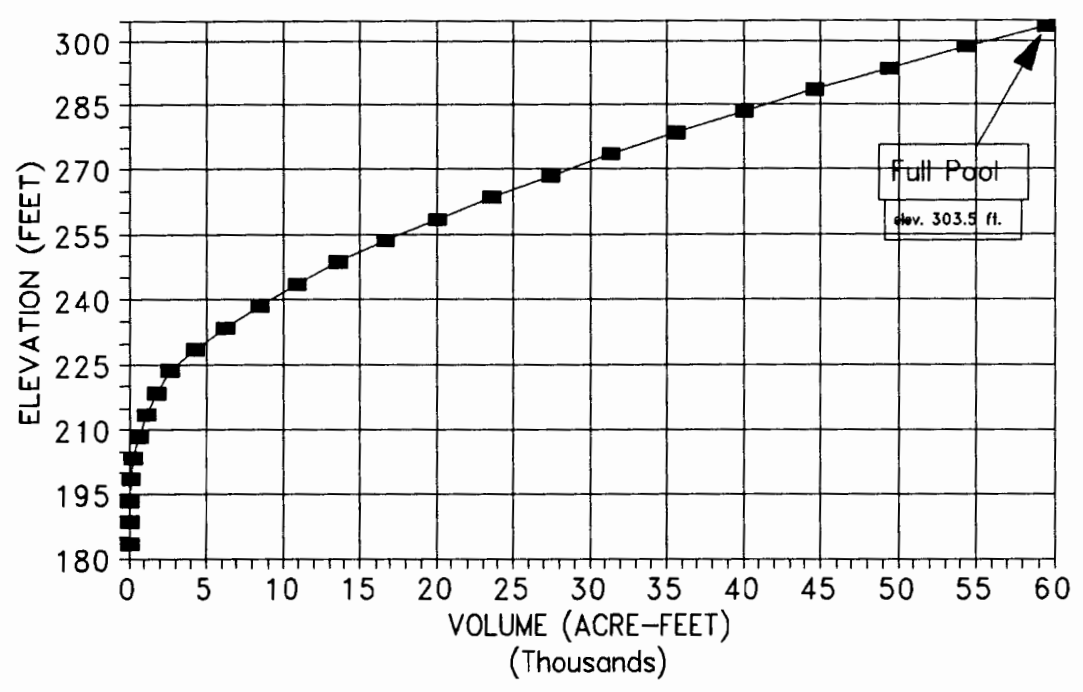

Figure 8. Volume versus Elevation curve for Henry Hagg Lake.

According to Figure 8, the SURFER generated bathymetry agreed well with prior estimates of the full pool volume of 59,910 acre-feet.

The Manning coefficient for friction is specified for each cell and is located in the bathymetry file. However, for the Hagg Lake Model, velocities are so low that friction does not play a large role. A value of 0.020 was used for all longitudinal cells. 
HAGG LAKE METEOROLOGICAL DATA

The meteorological data necessary for running the Hagg Lake model were obtained from numerous sources for the years 1990 and 1991. Air temperature data were obtained from Mr. George Taylor, the oregon state Climatologist. These data were taken daily in the form of $\mathrm{T}(\min ), \mathrm{T}(\max )$, and $\mathrm{T}(\mathrm{ave})$ from three different stations in the Tualatin Basin: Hillsboro, Forest Grove, and Beaverton. The Hillsboro temperature data were the most complete, therefore, they were used for model simulations. Since there were no complete relative humidity data available for the basin, the daily $\mathrm{T}(\mathrm{min})$ data compiled by $\mathrm{Mr}$. Taylor were used as an approximation for the dew point temperature. Hourly wind speed, hourly wind direction, and hourly cloud cover data were obtained from the Hillsboro Airport, these data were then averaged to daily values. The cloud cover data obtained were based on an observed 0 to 100 percent cloudy basis.

These data were placed into two files as input to the CEQUAL-W2 model, "MET90.NPT" and "MET91.NPT", based on Julian day.

\section{HAGG LAKE INFLOWS AND OUTFLOWS}

The Hagg Lake model was created using one branch with an inflow at the upper end (Scoggins Creek) and an outflow at the opposite end (Scoggins Dam). Two other main tributaries feed into this lake, Sain Creek and Tanner creek. Tributary files 
for each sain and Tanner creeks were created designating flow, temperature, and water quality parameters as a function of Julian day. CE-QUAL-W2 requires an output file at the end of every branch (cell 30 for Hagg Lake). Since the outflow intake structure is not located at the dam, the outflow file consisted of zero flow. A withdrawal file was created for the outflow intake structure location (cell 29) (see chapter V).

In researching the historical records of Hagg Lake, no previous detailed water quality studies had been done on this lake and water quality data were very limited. The only water-quality data found on the lake were from the Unified Sewerage Agency (U.S.A.). These consisted of sporadic water quality and temperature data from the summers of 1978 through 1985, and more complete data from its three major tributaries (Scoggins Creek, Sain Creek, and Tanner Creek) from the summer of 1989. Because these data were incomplete and out of the model study period, they were used only as a reference. other water quality data were found in the "Atlas of oregon Lakes" for two dates: 5-9-75 and 10-7-81 (Johnson et. al., 1985). Some data were also obtained from a volunteer "Citizen Lake Watch" program for the summer of 1990 that provided some temperature and turbidity data.

Good hydraulic data (i.e., inflows, outflows, change in storage, etc.) existed for Hagg Lake. A monthly report, "Scoggins Dam Reservoir operations", has been maintained by the Scoggins Dam operator for every month of the dam's 
operation. This report was obtained from the Tualatin Valley Irrigation District (T.V.I.D.) for all months in the study period. The report has daily inflow measurements for sain and Scoggins Creeks, daily water surface elevations, daily outflow releases, daily computed changes in storage, and daily computed total inflows (change in storage minus the outflow). Therefore, inflow files were set up for Scoggins and Sain Creeks from these data and Tanner creek flows were estimated (see Chapter V).

CE-QUAL-W2 requires three files for every inflow: a flow file, a temperature file, and a constituent concentration file. Since no inflow temperature data existed for the study period, these parameters were estimated from temperature data of creeks in nearby sub-basins. Using U.S.A. data from Carpenter Creek and the Upper Tualatin River, and comparing these Creek's temperatures with data on Scoggins, Sain, and Tanner Creeks in 1989 (U.S.A.), trends in temperature were determined and inflow temperature files were created for Hagg Lake inflows. No inflow water quality constituent data existed for these creeks in the study period either, and they were estimated. After reviewing data on creeks in nearby subbasins, it was determined that water quality parameters were fairly consistent from one summer to the next. Also, a report on the Tualatin River Basin by Miner \& Scott (1992) showed that most of the inflow during the summer months came from groundwater sources and there are relatively few storms during 
the summer. Therefore, constituent inflow files were created for the three creeks using the 1989 U.S.A. data.

\section{OTHER INPUT FILES}

As mentioned in Chapter III, the most important file for running CE-QUAL-W2 is the control file. This file contains all of the coefficients for the model simulation, initial conditions, time step parameters, the running time, the output control, and maps to other input files. Since determining many of the values for this file was a process of calibration, this file is discussed in the following chapter.

Another important input file is the "include file". This file tells the program where the control file is and it also lists important parameters for model simulation, such as the number of tributaries.

other files were also created for model output. one may see a list of all files used in the Hagg Lake Model along with their description in Appendix $C$. 


\section{CHAPTER V}

\section{HAGG LAKE CALIBRATION}

\section{INTRODUCTION}

The process of model calibration is the most time consuming and the most important step in creating a complex hydraulic-water-quality model of a natural system. The calibration process consists of setting preliminary values of model parameters, running the model, comparing model predictions with measured data, and iterating on this process while changing input parameters until a reasonable model-data agreement existed. This iterative process would continue until a "satisfactory" correlation existed between model output and the data (Walesh, 1989).

However, since water quality and some hydrologic data for Hagg lake did not exist, the lake was calibrated with the limited data available. The model was calibrated for the summer of 1990. Summer runs of the lake were made from May Ist to October 31st, since the lake was to be filled by May 1st.

HAGG LAKE INITIAL CONDITIONS

The initial conditions of Hagg Lake were of utmost importance to predicting the summer water quality of the lake 
because detention times are approximately on the order of 1 year. During the summer, downstream demands are at their peak and there is very little inflow to the lake, therefore, at the beginning of the summer when the lake is full, the initial concentration of water quality parameters must be specified correctly so that water quality predictions of the lake will be accurate.

Most of the water quality and hydraulic parameters, as well as initial concentrations, were set through trial \& error during the calibration process. However, with some of the limited data available, some initial conditions were established. The data from the "Atlas of Oregon Lakes" provided some profiles of temperature and dissolved oxygen for the beginning of May, 1978 (Johnson et. al., 1985). Since summer runs began on May 1st, the profiles of dissolved oxygen and temperature were good references for initial summer conditions. Initial summer profiles for both temperature and dissolved oxygen were obtained from spring model runs. For temperature, an initial temperature of $6^{\circ} \mathrm{C}$ was assumed and the lake was assumed to be well-mixed on March 1, 1990. The 1990 model was run, and a profile of temperature for May 1,1990 was created. An initial summer profile for dissolved oxygen was obtained from the same model simulation using a wellmixed-initial-saturated dissolved oxygen concentration at $6^{\circ} \mathrm{C}$ (equal to $12.45 \mathrm{mg} / \mathrm{l}$ ). These profiles were checked against the profile data from 1978. The profiles were very similar 
and the ones generated by the model were used for 1990 initial conditions. Figures 9 and 10 show simulated profiles for April 1, 1990 and May 1, 1990 for temperature and dissolved oxygen, respectively. The initial profiles for May 1st were used for the 1990 initial conditions.

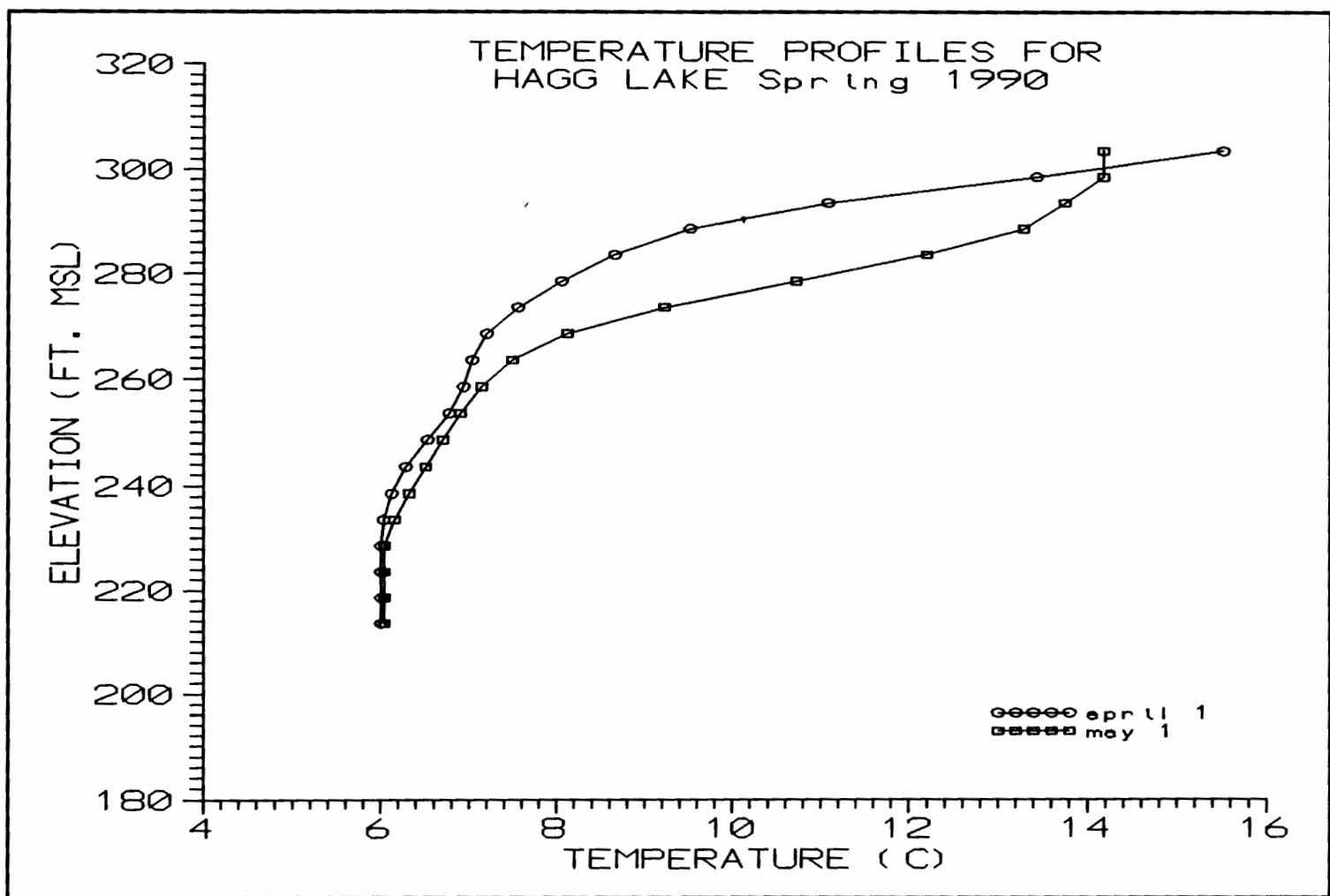

Figure 9. Summer initial temperature profile (May 1 , 1990) used for Hagg Lake Calibration (simulated). 


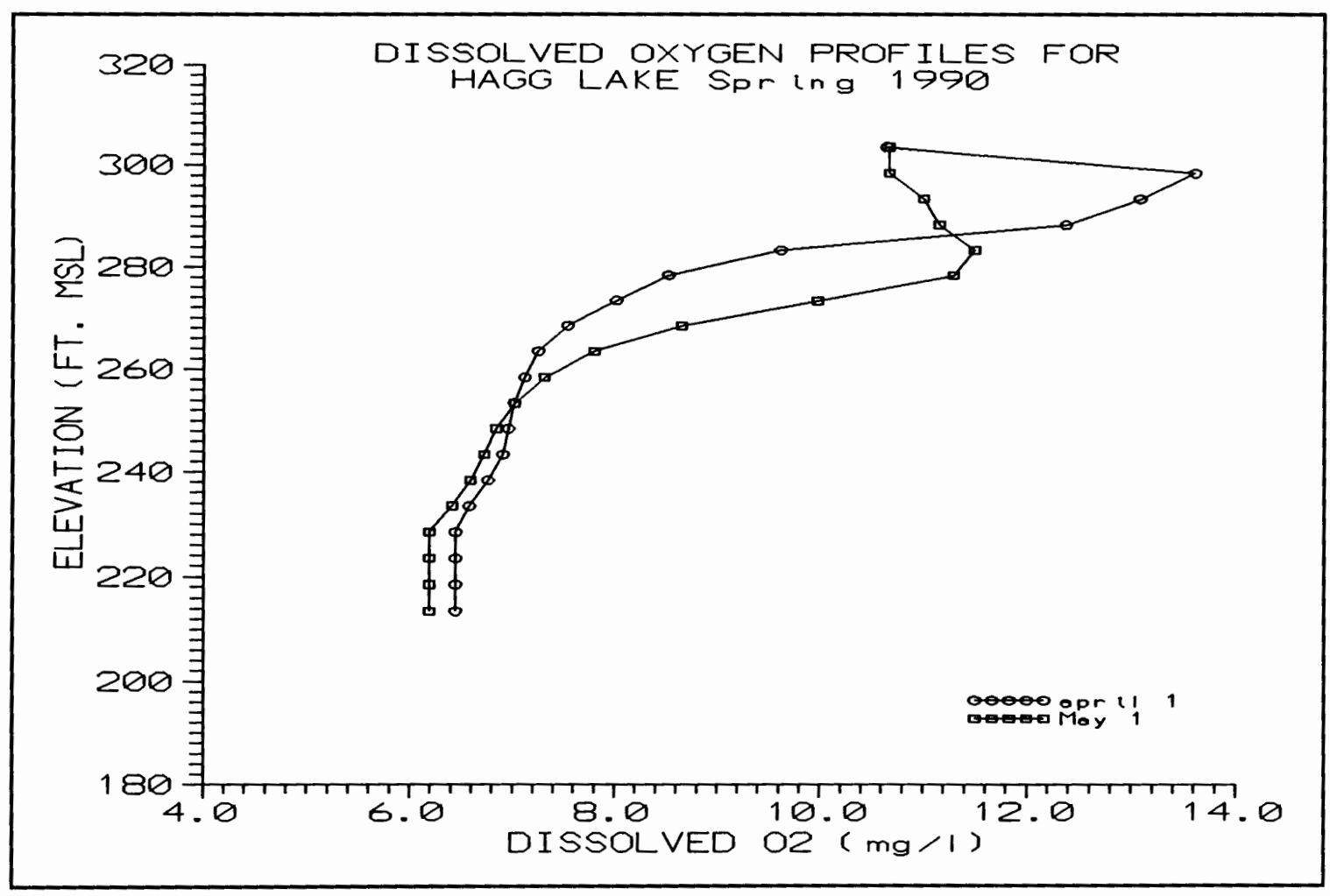

Figure 10. Summer initial conditions (May 1, 1990) used for dissolved oxygen profiles in Hagg Lake (simulated).

The data from "the Citizen Lake Watch" provided Secchi Disk depths for five days during the summer of 1990. Two of these days were "sunny", and three were "overcast", the two "sunny" days were thrown out and the "overcast" data points were averaged to give an average secchi disk depth. Many empirical relations of secchi disk depth to light extinction in a water body have been made. Sverdrup et al. (1942) and Beeton (1958) and others have developed empirical relationships between the secchi disk depth and the total light extinction coefficient as (Thomann and Mueller 1987): 


$$
X_{c}=\frac{1.8}{Z_{s}}
$$

Where $Z_{s}$ is the secchi Disk depth $(m)$ and $x_{c}$ is the total extinction coefficient $\left(\mathrm{m}^{-1}\right)$. A result of $0.46 \mathrm{~m}^{-1}$ was found using this equation for the total extinction coefficient.

CE-QUAL-W2 sums three different extinction coefficients for the total extinction coefficient: light extinction due to water, light extinction due to inorganic particles, and light extinction due to organic particles. The two particle extinction coefficients were multiplied by their respective organic and inorganic constituent concentrations and these values were added to the extinction coefficient due to water. Since CE-QUAL-W2 determines the total extinction coefficient as a variable dependent on particle concentrations, the total extinction coefficient calculated above was used as a reference value. Once the temperature was calibrated, average organic and inorganic particle concentrations were multiplied by their calibrated extinction coefficients. The results were summed with the calibrated water extinction coefficient to compare to the reference total extinction coefficient value of $0.46 \mathrm{~m}^{-1}$.

\section{CALIBRATION OF HYDRAULICS}

As shown before, data for Hagg lake inflows and outflows were recorded by the Scoggins Dam operator on a daily basis. Inflow data consist of flow rates on a daily basis of the two 
main tributaries to the lake: Scoggins and Sain Creeks. Some data were available for Tanner creek inflows, but not during the study period. Tanner Creek apparently flowed at approximately one-third the volume of sain creek during a period when data for both creeks were available. Therefore, Sain Creek inflows were multiplied by one-third to estimate Tanner creek inflows. Other minor tributaries to the lake were considered insignificant. In addition to these data, staff gauge readings were taken on a daily basis, and these data were converted to a daily "change in storage" from the volume versus elevation curve for this lake. This "change in storage" represents the 24 hour change from all processes of the lake's water budget (i.e., precipitation, evaporation, inflow, and outflow including seepage.). CE-QUAL-W2 has the capability of computing evaporation and precipitation storage changes, however, since the model simulations were during the summer, when little precipitation occurs, precipitation was turned off. Therefore, the Hagg Lake model predicts evaporation only. Daily inflows and outflows were input to the model.

In order to calibrate the water budget for Hagg Lake, a graph of the inflows computed by the model (i.e., inflowevap.) were compared to those computed from the "change in storage" data (i.e., inflow-evap.+precip.-seepage) (see Figure 11). This graph was used to calibrate the inflows. During periods when the model over predicted inflows, the inflows 
were reduced by the appropriate amount. This reduction is justified by the error involved in using a point measurement for inflow when compared to the actual variation of inflow during a daily period. From the graph, one can see that the two curves fit each other well, but the curve computed from the "change in storage" data is unsteady, shifting up and down across the model's curve. These differences could be due to errors in reading the staff gauge at Hagg Lake or from diurnal storage variations not accounted for in the model.

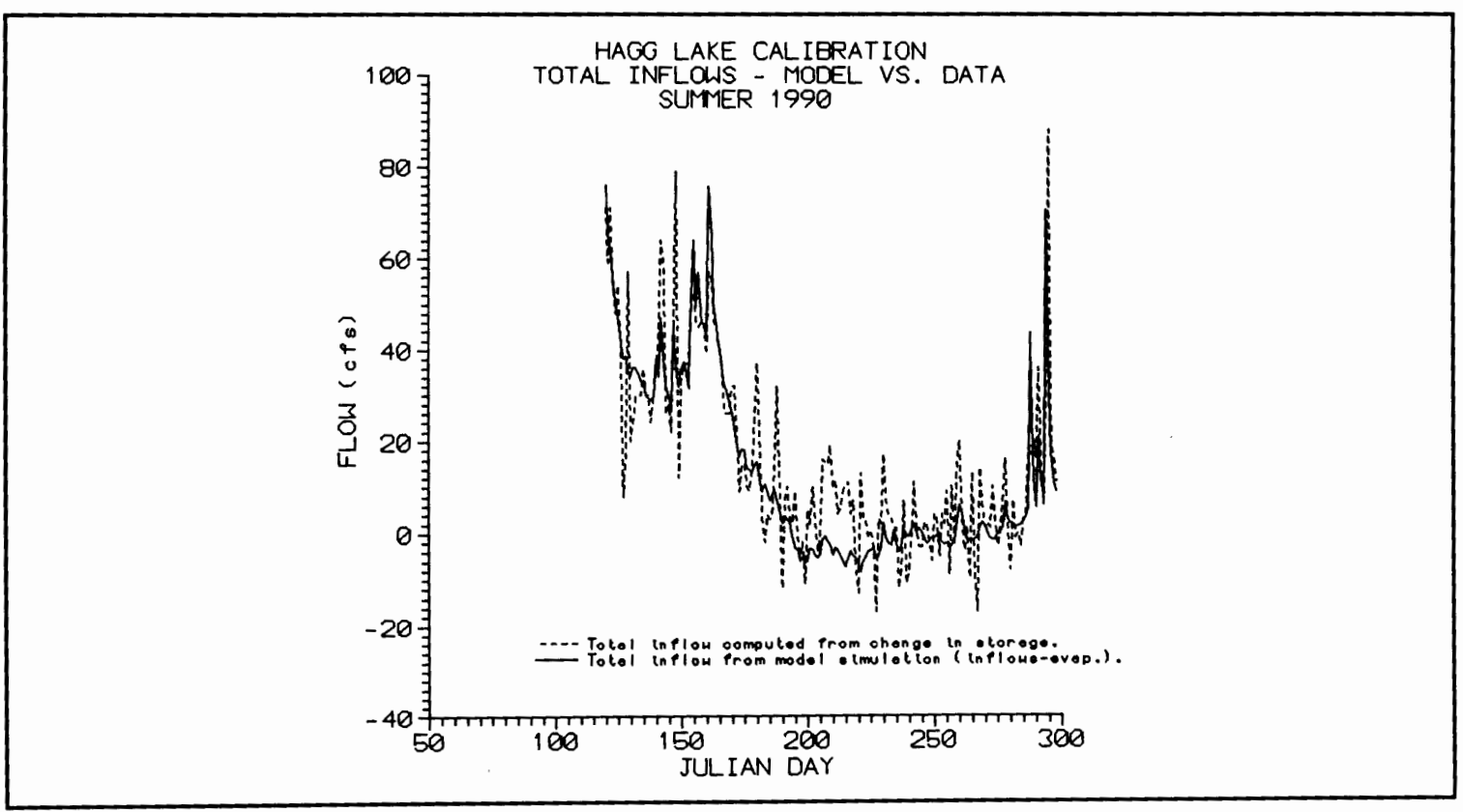

Fiqure 11. Total Hagg Lake inflows computed from "change in storage" data versus total Hagg Lake inflows computed by model for the summer of 1990 .

Outflow data from the lake were not calibrated since these data were known. However, calibration was performed on the outflow hydraulics of the outlet structure. Dam 
construction records were analyzed to place the outflow structure in the model. The intake to the outflow structure was placed in longitudinal cell 29 and vertical cells 14, 15, and 16. Three new parameters were created to account for the amount of outflow from each of the three vertical cells (fract1-fraction of outflow from cell 14, fract2-fraction of outflow from cell 15, and fract3-fraction of outflow from cell 16). The three new parameters were varied via a new input file (outlet.npt) which was read at the beginning of each model simulation. The following two diagrams show how the outflow intake structure was modeled. Figures 12 and 13 show the longitudinal cell location and the vertical cell placement of the outflow intake structure, respectively.

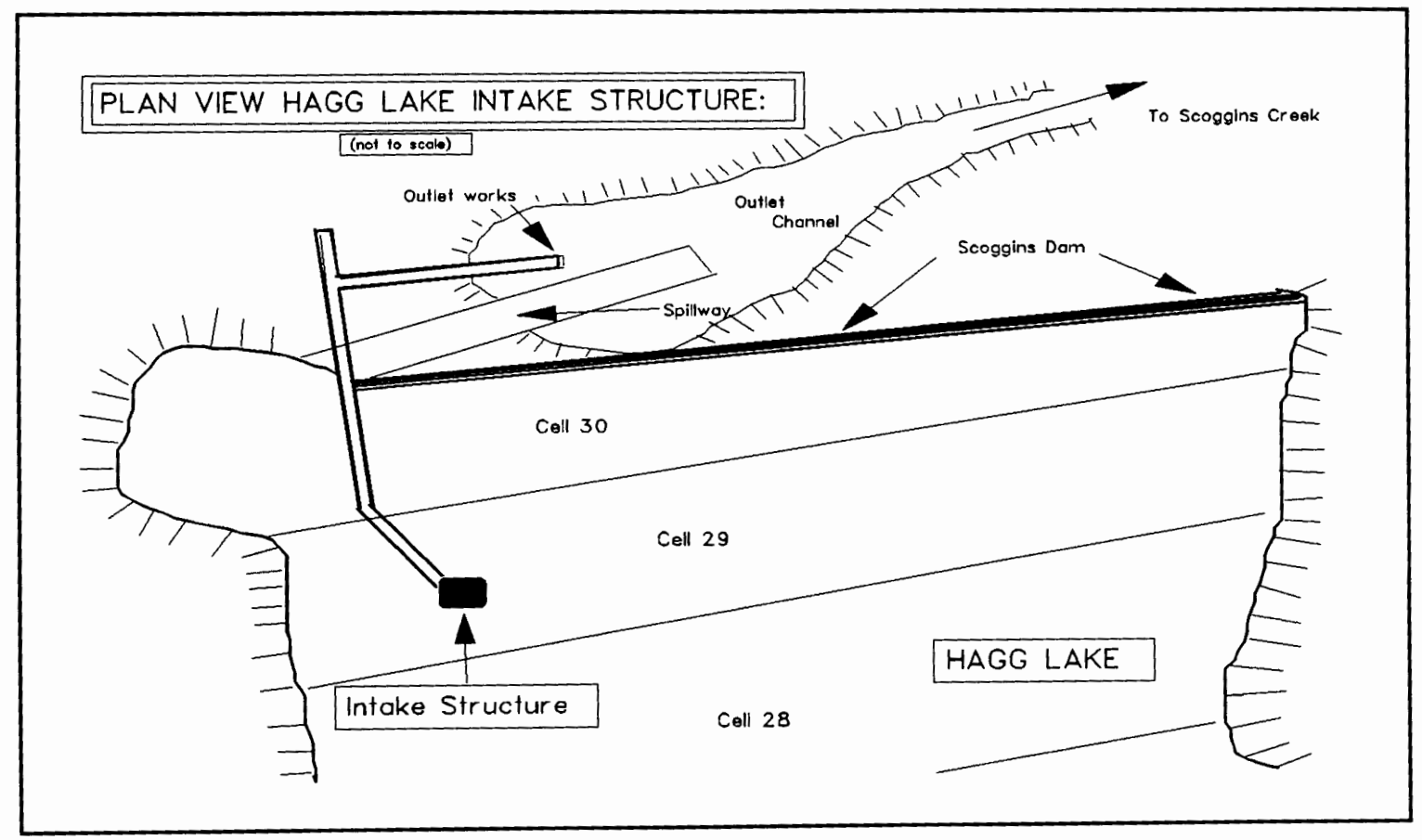

Figure 12. Hagg Lake outflow Intake structure plan view location. 


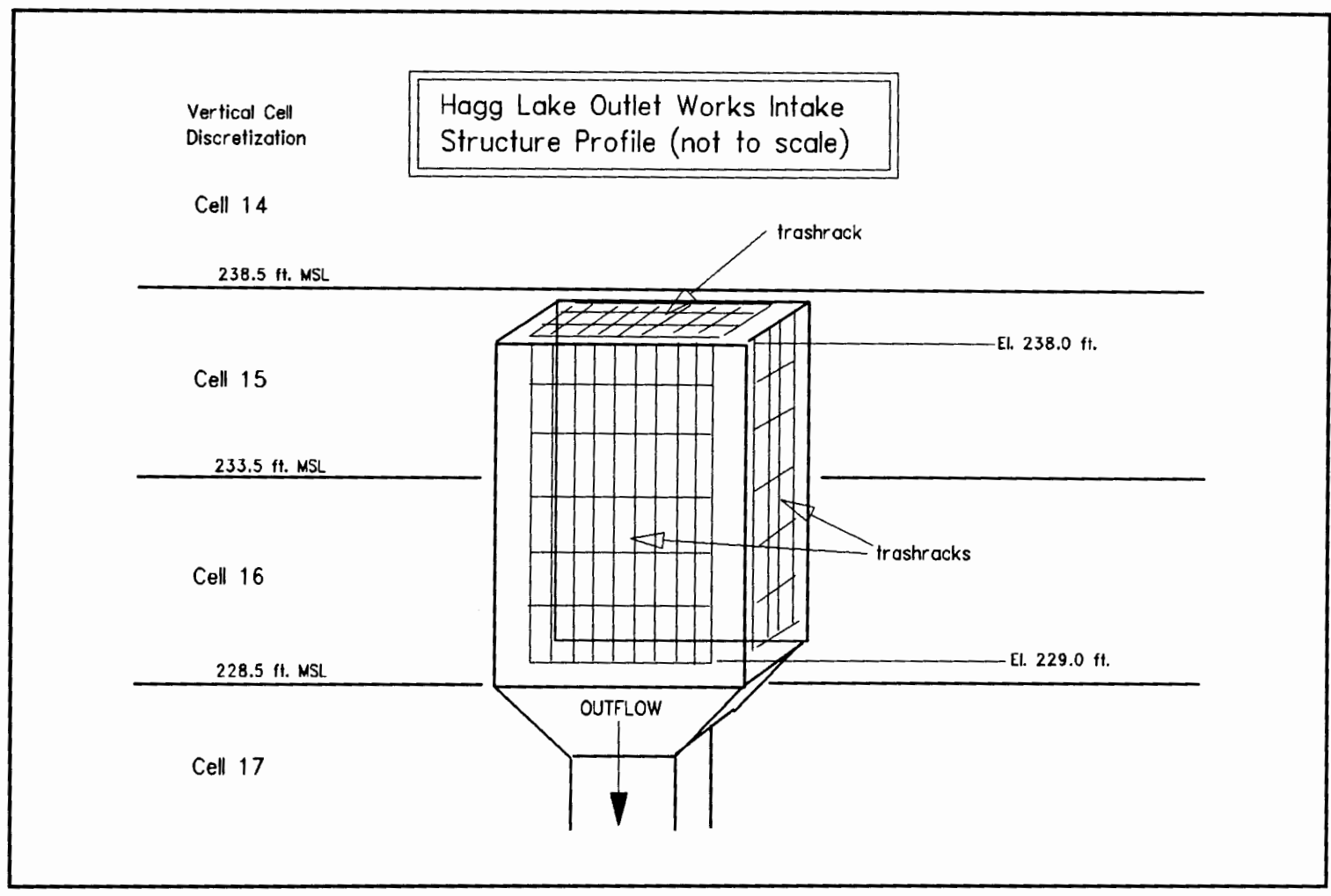

Figure 13. Hagg Lake Outflow Intake Structure Profile view.

In order to see how well the model predicted the hydraulics of the lake, Figure 14 shows the modeled water surface elevation predicted versus water surface data compiled by the Dam operator and obtained from the Tualatin Valley Irrigation District during the 1990 summer simulation period. 


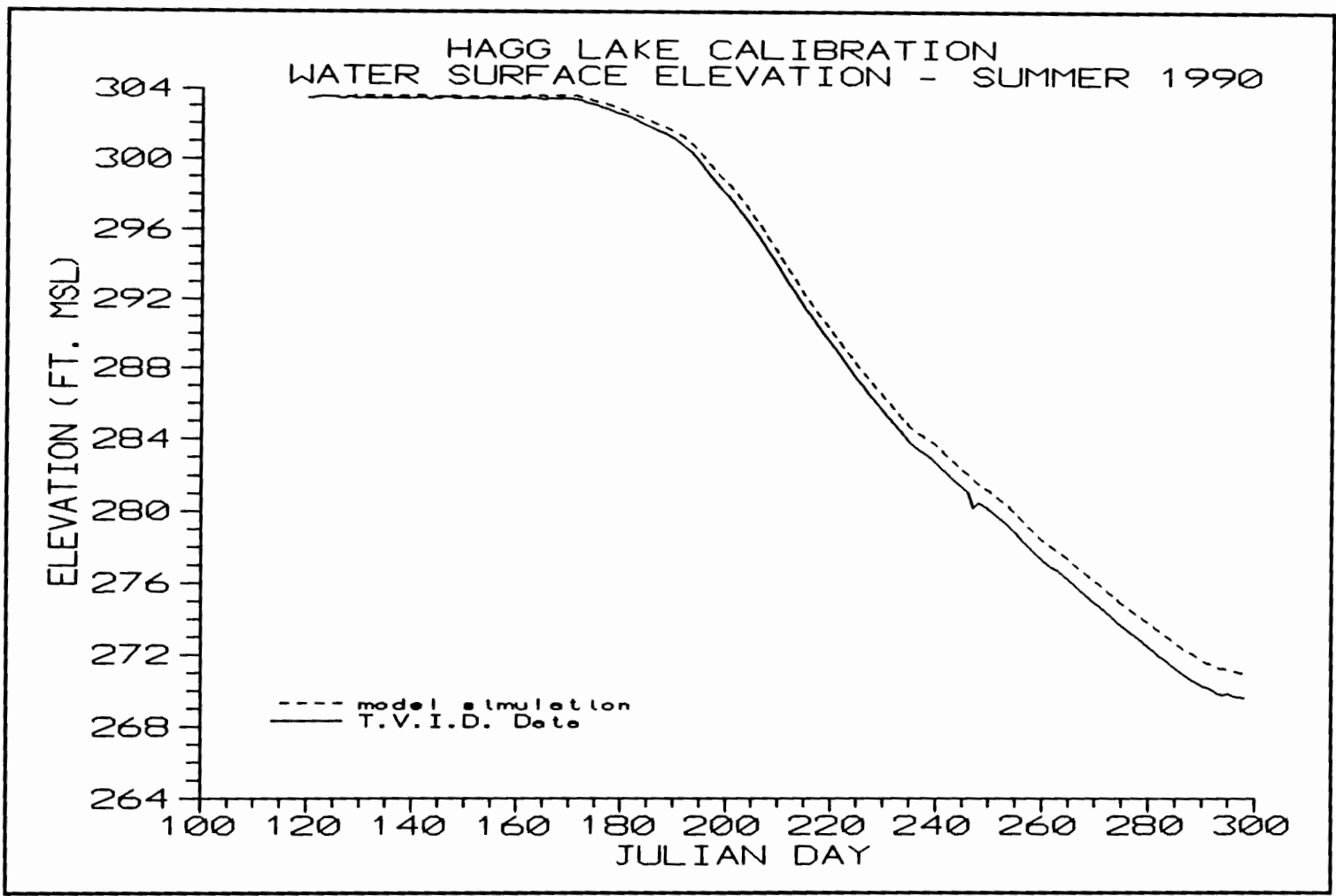

Figure 14. Hagg Lake water surface elevation predicted versus actual for the summer of 1990 .

From Figure 14, the model predicts the same water surface elevation for the first 45 days of the simulation as the data. From Julian day 165 (June 16) to Julian day 225 (August 13), the model over predicts the water level by approximately five inches. From Julian day 225 to the end of the simulation, the model begins to diverge from the actual curve at an almost constant rate, until the end of the simulation, where it overpredicts the water surface elevation by approximately one foot four inches. At the same time that the model begins to diverge from the actual curve around Julian day 225, demand from the reservoir begins to peak, and drawdown of the 
reservoir begins to become significant. If the bathymetry used in the model has a larger pool than was actually available during this period, then this difference in volume versus elevation could cause this discrepancy. This theory has merit since the topographic map used to establish the bathymetry of the lake was made during the construction of the reservoir in approximately 1970. In the twenty years since then, sedimentation in the lake bottom could cause this difference in volume versus elevation. Since the discrepancy was minor, the bathymetry was not changed. Also, this error could be from neglecting seepage through the dam and other minor sources and sinks of water.

CALIBRATION OF WATER QUALITY CONSTITUENTS AND TEMPERATURE

For this study, 17 of the possible 22 water-quality parameters (Chlorophyll-a, TDS, TSS, BOD-L, BOD-R, Detritus, $\mathrm{PO}_{4}-\mathrm{P}, \quad \mathrm{NH}_{3}-\mathrm{N}, \mathrm{NO}_{3}-\mathrm{N}, \mathrm{O}_{2}, \mathrm{pH}$, Carbon, Alkalinity, $\mathrm{CO}_{2}$, Bicarbonate, Carbonate, and Zooplankton) and temperature were calibrated.

Summertime water quality data records were obtained from U.S.A. for the outlet channel, Scoggins creek, for all years in the study period. Since these data were the only historical records of water quality that were both in the study period and somewhat complete, these data were used to calibrate the water quality of the model. For a given model simulation, model output data at the point of outflow were 
compared to U.S.A. data on Scoggins Creek. It was assumed that little change occurred between the outflow intake structure and the point of sampling downstream (approximately 1300 feet). This meant that for any given constituent being analyzed, a proportion (fract1, fract2, and fract3) of its concentration from vertical cells 14,15 , and 16 within longitudinal cell 29 were summed and compared to available U.S.A. data downstream.

The CE-QUAL-W2 model places model output results in a large snapshot file (snp.opt) which makes the calibration process tedious. Some minor additions to the source code were made which placed model predictions of water quality from the outlet intake cells in a format that could be analyzed more easily.

In order to plot these data readily for each of the Hagg Lake model simulations, a series of FORTRAN sorting programs were run in a batch file that placed results in a form compatible with the software program GRAPHER which in turn plotted the results. The following six figures (figures 15, $16,17,18,19$, and 20) contain the graphs of water quality constituents used for calibration of each model simulation. These graphs were from the final calibration run. As one can see, of the 17 water quality constituents (including temperature), only seven constituents $\left(\mathrm{PO}_{4}-\mathrm{P}\right.$, temperature, $\mathrm{NH}_{3}-\mathrm{N}, \mathrm{NO}_{3}-\mathrm{N}, \mathrm{pH}, \mathrm{TDS}$, and TSS) had data for calibration comparisons. 


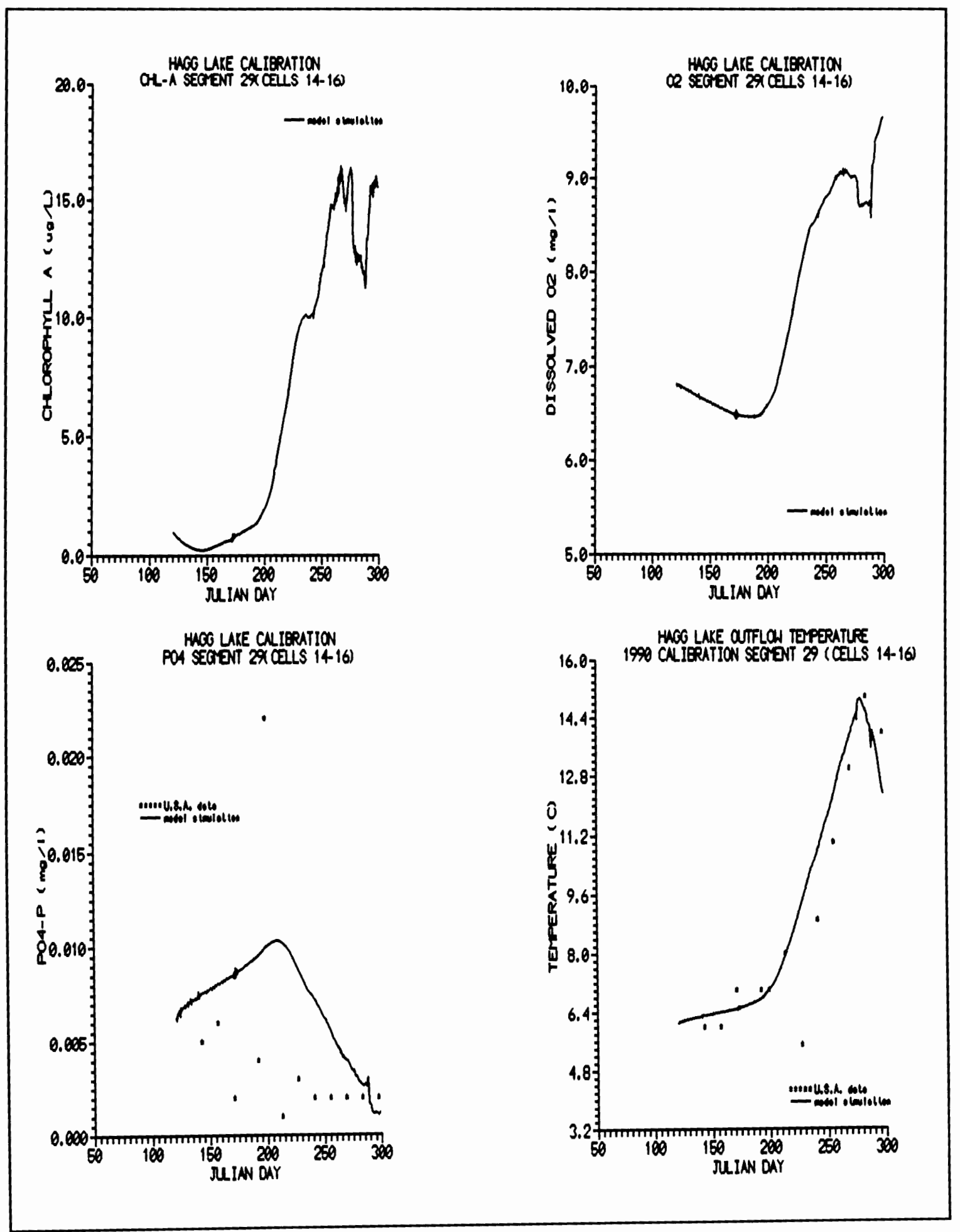

Figure 15. Hagg Lake calibration results for Chlorophyl1-a, $\mathrm{PO}_{4}-\mathrm{P}, \mathrm{O}_{2}$, and Temperature for the summer of 1990. 


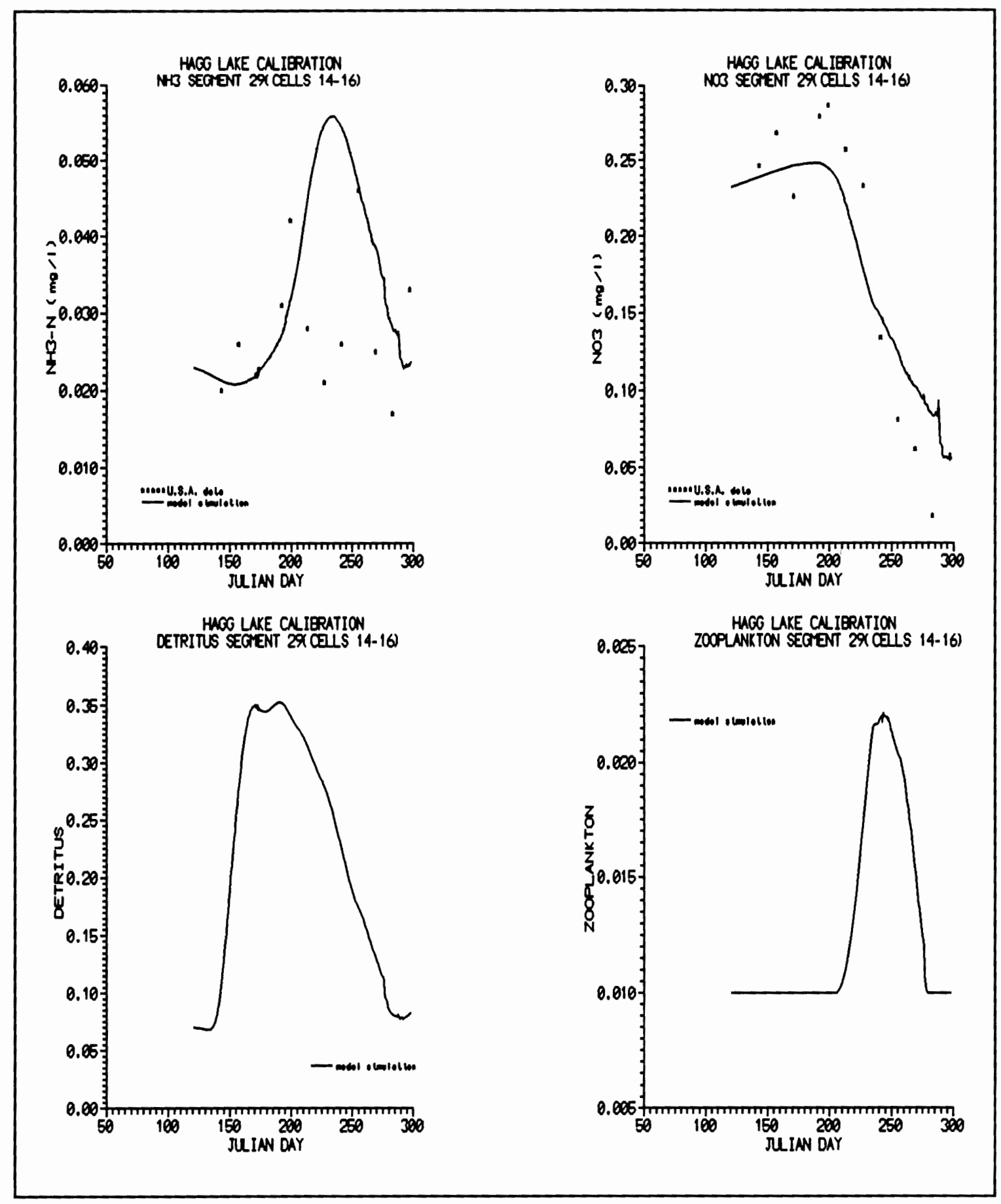

Figure 16. Hagg Lake calibration results of $\mathrm{NH}_{3}-\mathrm{N}$, Detritus, $\mathrm{NO}_{3}-\mathrm{N}$, and Zooplankton for the summer of 1990. 
HMGG LAKE CNIERATION

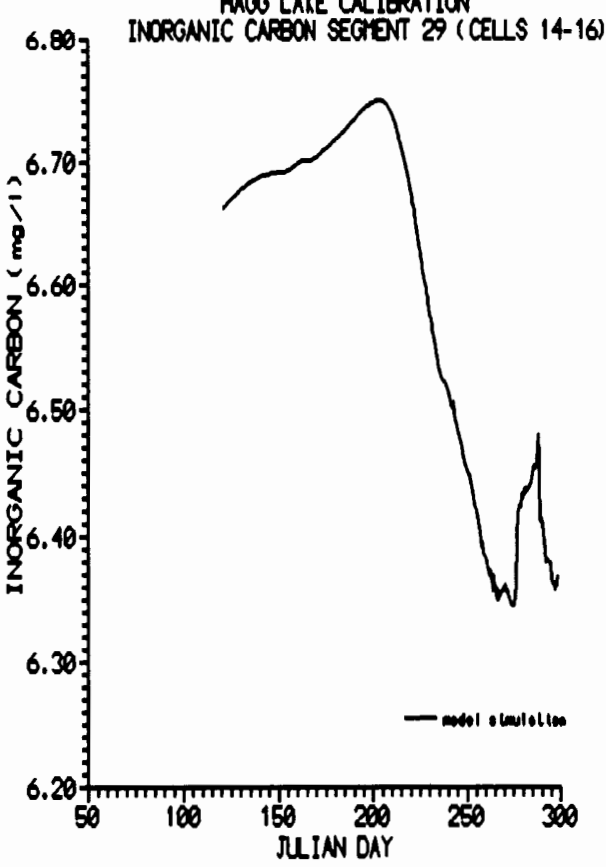

HWOG LAKE CNIBRATION

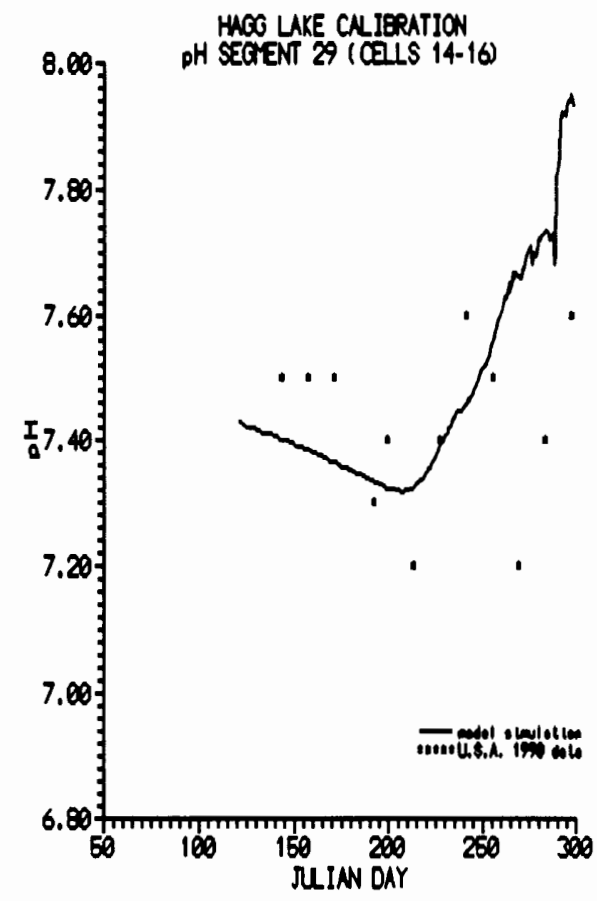

HUGG LAKE CUIBRATION
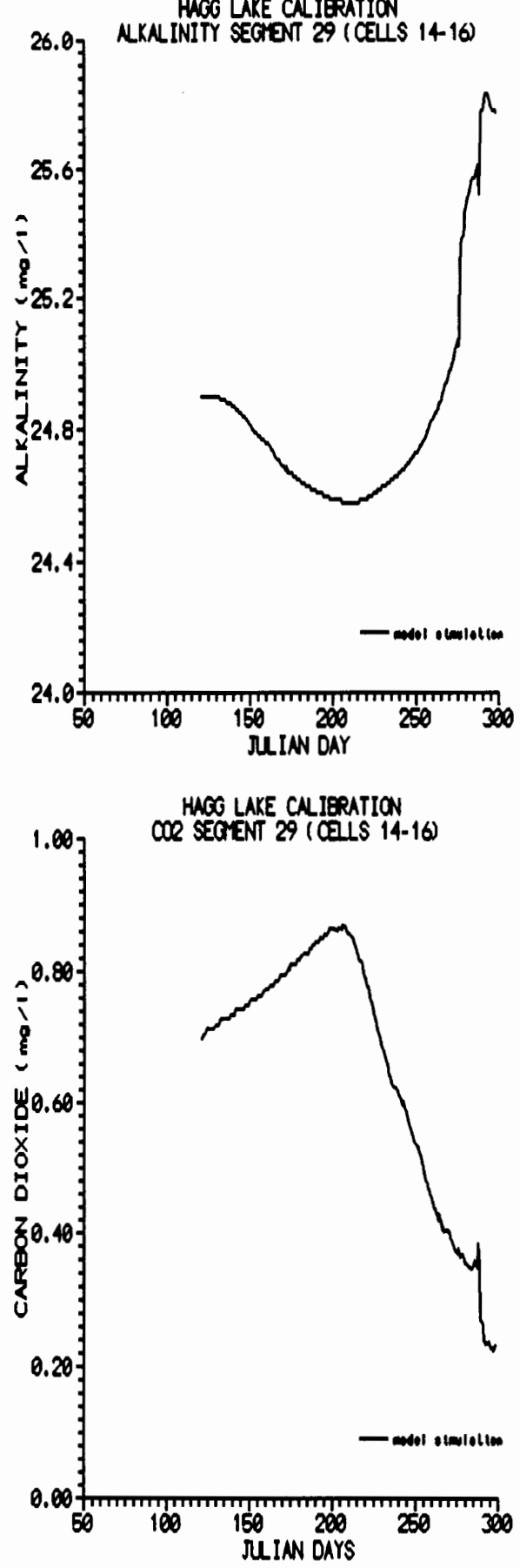

Figure 17. Hagg Lake calibration results for Inorganic Carbon, Alkalinity, $\mathrm{pH}$, and $\mathrm{CO}_{2}$ for the summer of 1990. 


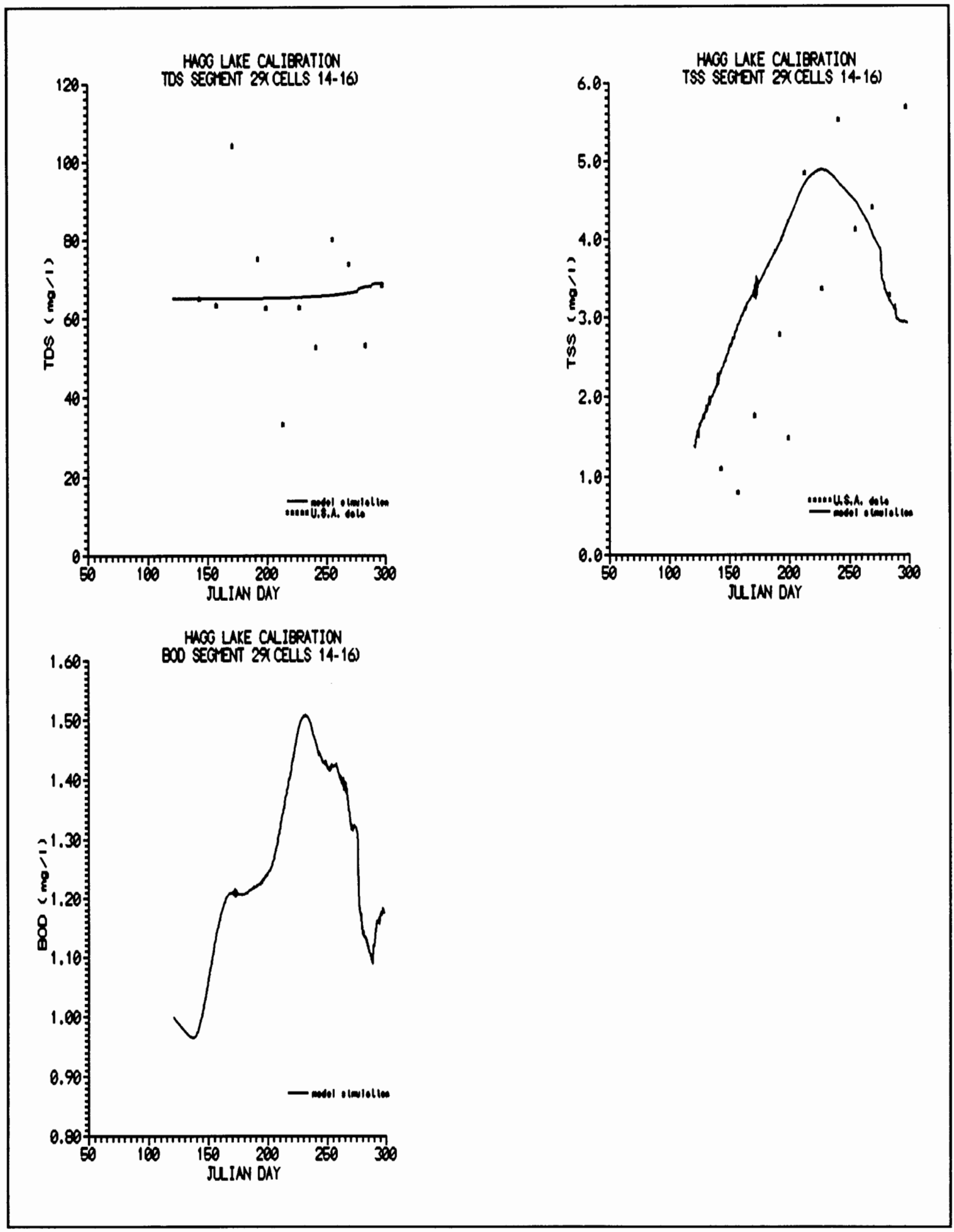

Figure 18. Hagg Lake calibration results for TDS, TSS, and BOD for the summer of 1990. 


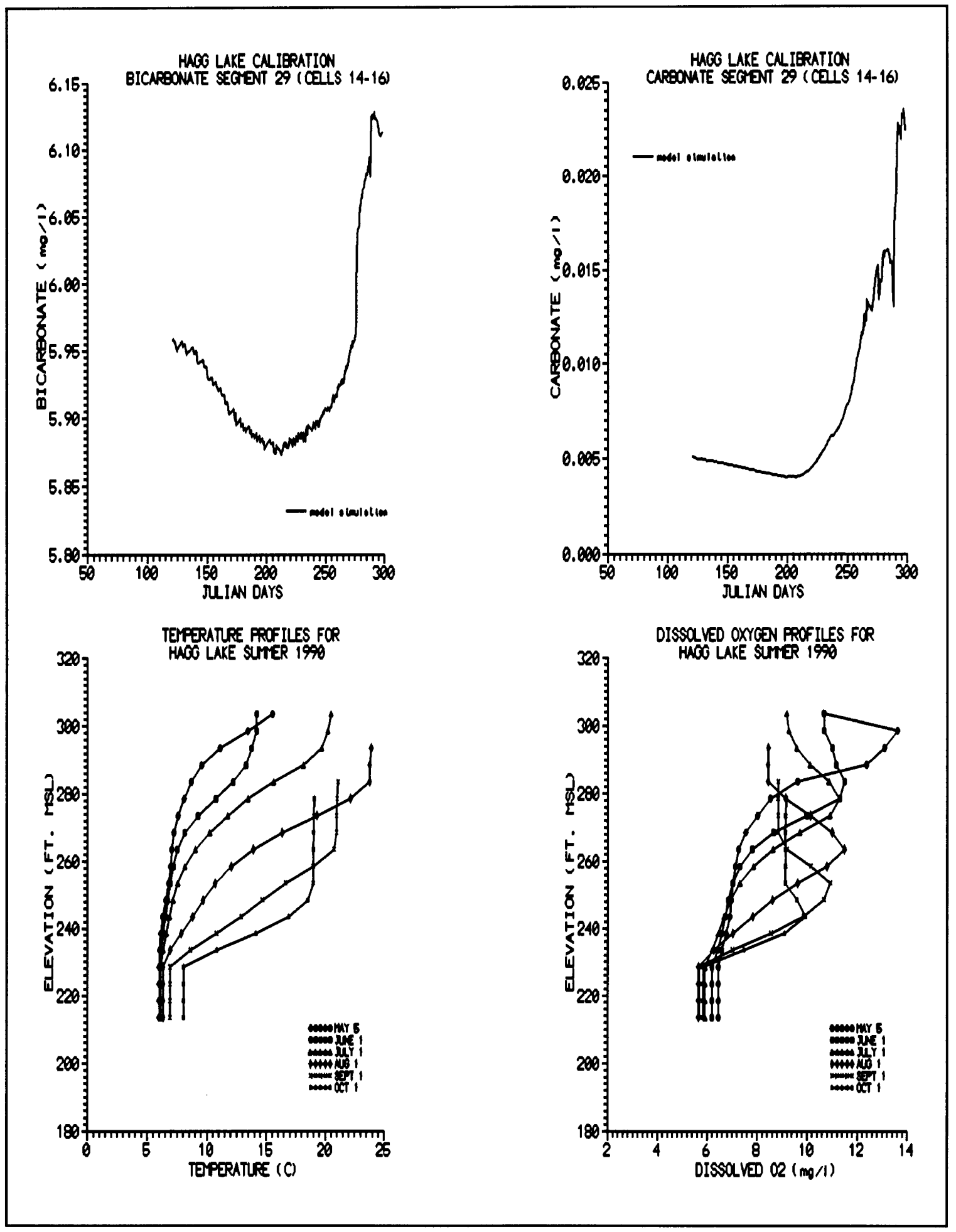

Figure 19. Hagg Lake calibration results for Bicarbonate, Carbonate, and profiles of Temperature and $\mathrm{O}_{2}$, for the summer of 1990 . 


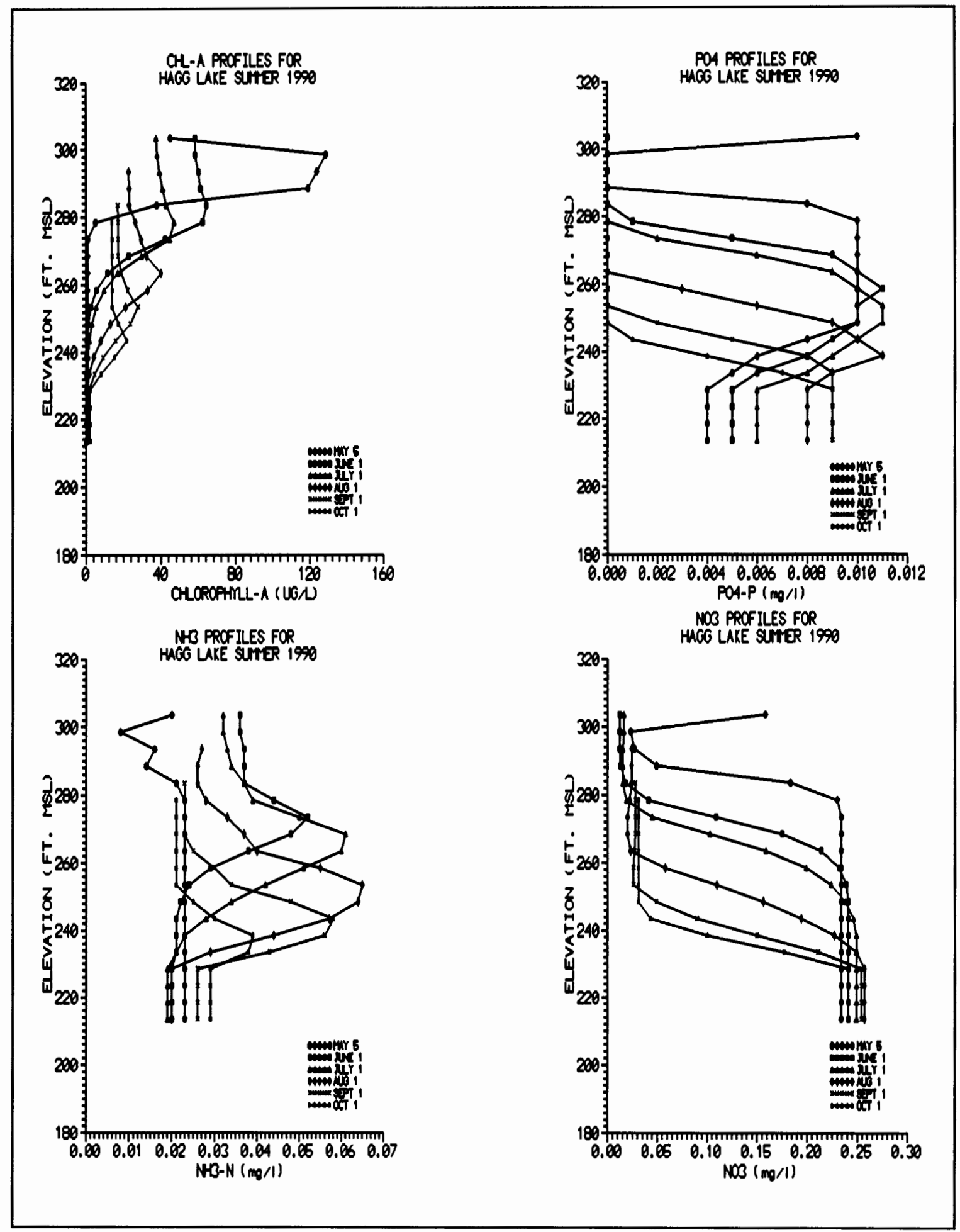

Figure 20. Hagg Lake calibration profiles of Chlorophyll-a, $\mathrm{PO}_{4}-\mathrm{P}, \mathrm{NH}_{3}-\mathrm{N}$, and $\mathrm{NO}_{3}-\mathrm{N}$ for the summer of 1990. 
Since only 7 of the 17 constituents modeled including temperature had field data available for calibration, precise calibration was difficult. The calibration process went as follows. First temperature was calibrated with the water quality constituents turned off. Next, all water quality constituents shown above besides inorganic carbon, alkalinity, $\mathrm{CO}_{2}$, bicarbonate, carbonate, and $\mathrm{pH}$, were turned on and TSS was calibrated. TSS and BOD were treated differently in the modeling process than other constituents. CE-QUAL-W2 simulates inorganic suspended solids (ISS), but not total suspended solids (TSS), therefore, detritus, algae, zooplankton, a fraction of BOD-L (25\%), and a fraction of BOD$R(75 \%)$ were summed with IsS to determine the total suspended solids concentration. As for BOD, CE-QUAL-W2 simulates labile-BOD (BOD-L) and refractory-BOD (BOD-R), but not total BOD, therefore, a fraction (50\%) of detritus and of algae were summed with BOD-L and BOD-R to achieve a total BOD concentration. Calibration of total dissolved solids (TDS) followed, however, the model treats TDS as a conservative parameter, therefore, an initial condition of $63 \mathrm{mg} / \mathrm{l}$ was set for TDS from analysis of the TDS field data. $\mathrm{PO}_{4}-\mathrm{P}, \mathrm{NH}_{3}-\mathrm{N}$, and $\mathrm{NO}_{3}-\mathrm{N}$, were calibrated next. These three parameters are highly dependent on algae populations, which are dependent on most other parameters being modeled. Algal limiting factors were shown in the "snapshot" output file produced by CE-QUALW2. Algal populations were limited by ortho-phosphorus 
rather than nitrogen for nearly the entire simulation period. This was due to the very low ortho-phosphorus concentrations used in the lake from analysis of U.S.A. field data. A chlorophyll-a to algae ratio of $50 \mu \mathrm{g} / 1$ chlorophyll-a to 1 $\mathrm{mg} / \mathrm{l}$ algae was used. The fact that the CE-QUAL-W2 model was only able to model one algal population with one chlorophyll-a production rate for the dynamic summer season limited the water quality calibration. Finally, inorganic carbon, alkalinity, $\mathrm{CO}_{2}$, bicarbonate, carbonate, and $\mathrm{pH}$ were added to the model. Data on Scoggins Creek existed for $\mathrm{pH}$, and these six parameters were calibrated using these data. This consisted primarily of establishing appropriate initial conditions for these parameters. The following method was used to establish initial conditions for these six parameters: Alkalinity and bicarbonate used U.S.A. data averages for years 1978-1985; $\mathrm{CO}_{2}$ and carbonate were proportioned from average bicarbonate concentrations (Wetzel, 1975); and the initial inorganic carbon was determined using the initial $\mathrm{pH}$ and alkalinity from a chart in " Principles of surface water Quality Modeling and Control" (Thomann and Mueller, 1987).

The following table lists all model coefficients, their description and values used for calibration of the CE-QUAL-W2 model for Hagg Lake. 
TABLE I

HAGG LAKE CALIBRATED COEFFICIENT VALUES

\begin{tabular}{|c|c|c|}
\hline $\begin{array}{l}\text { COEFFICIENT } \\
\text { (Variable in } \\
\text { source/sink } \\
\text { Term in } \\
\text { Appendix A): }\end{array}$ & $\begin{array}{l}\text { HAGG } \\
\text { LAKE } \\
\text { MODEL } \\
\text { VALUE : }\end{array}$ & DEFINITION: \\
\hline ITEMP & -1 & $\begin{array}{l}\text { Initial water temperature }(-1= \\
\text { initial profile in VPR file) } \\
\text { (C). }\end{array}$ \\
\hline WSC & 0.95 & $\begin{array}{l}\text { Wind sheltering coef. }(1.0= \\
\text { maximum wind, } 0.0=\text { no wind) }\end{array}$ \\
\hline $\mathrm{AX}$ & 10.0 & $\begin{array}{l}\text { Horizontal dispersion coef. for } \\
\text { momentum }\left(\mathrm{m}^{2} / \mathrm{sec}\right) \text {. }\end{array}$ \\
\hline IDX & 50.0 & $\begin{array}{l}\text { Horizontal dispersion coef. for } \\
\text { heat and mass }\left(\mathrm{m}^{2} / \mathrm{sec}\right) \text {. }\end{array}$ \\
\hline AZMIN & $1.4 e-6$ & $\begin{array}{l}\text { Minimum Horizontal Dispersion } \\
\text { coef. for momentum }\left(\mathrm{m}^{2} / \mathrm{sec}\right) \text {. }\end{array}$ \\
\hline DZMIN & $1.4 e-6$ & $\begin{array}{l}\text { Minimum vertical diffusion coef. } \\
\text { for heat and mass }\left(\mathrm{m}^{2} / \mathrm{sec}\right) \text {. }\end{array}$ \\
\hline DZMAX & 1.0 & $\begin{array}{l}\text { Maximum vertical diffusion coef. } \\
\text { for heat and mass }\left(\mathrm{m}^{2} / \mathrm{sec}\right) \text {. }\end{array}$ \\
\hline EXH2O & 0.40 & $\begin{array}{l}\text { Light extinction coef. for water } \\
\left(\mathrm{m}^{-1}\right) \text {. }\end{array}$ \\
\hline EXINOR & 0.05 & $\begin{array}{l}\text { Light extinction coef. for } \\
\text { inorganic particles }(\mathrm{m} / \mathrm{mg} / \mathrm{l}) \text {. }\end{array}$ \\
\hline EXORG & 0.05 & $\begin{array}{l}\text { Light extinction coef. for } \\
\text { organic particles }(\mathrm{m} / \mathrm{mg} / \mathrm{l}) \text {. }\end{array}$ \\
\hline BETA & 0.40 & $\begin{array}{l}\text { Fraction of solar radiation } \\
\text { absorbed at surface }(-) \text {. }\end{array}$ \\
\hline COLQ10 & 1.04 & $\begin{array}{l}\text { Q10 modification for coliform } \\
\text { die off rate. }\end{array}$ \\
\hline $\operatorname{COLDK}\left(\mathrm{K}_{\mathrm{c}}\right)$ & 1.4 & Coliform decay rate $\left(d^{-1}\right)$. \\
\hline $\operatorname{SSETL}\left(\omega_{1}\right)$ & 0.05 & $\begin{array}{l}\text { Suspended solids settling rate } \\
\text { (m/day). }\end{array}$ \\
\hline AGROW $\left(K_{g}\right)$ & 4.0 & $\begin{array}{l}\text { Maximum gross photosynthetic } \\
\text { production rate }\left(d^{-1}\right) .\end{array}$ \\
\hline
\end{tabular}


TABLE I

HAGG LAKE CALIBRATED COEFFICIENT VALUES (continued)

\begin{tabular}{|c|c|c|}
\hline $\begin{array}{l}\text { COEFFICIENT } \\
\text { (Variable in } \\
\text { source/sink } \\
\text { Term in } \\
\text { Appendix A): }\end{array}$ & $\begin{array}{l}\text { HAGG } \\
\text { LAKE } \\
\text { MODEL } \\
\text { VALUE: }\end{array}$ & DEFINITION: \\
\hline AMORT $\left(K_{m}\right)$ & 0.02 & $\begin{array}{l}\text { Maximum algal mortality rate (d } \\
\text { 1). }\end{array}$ \\
\hline $\operatorname{AEXCR}\left(\mathrm{K}_{\mathrm{e}}\right)$ & 0.04 & $\begin{array}{l}\text { Maximum excretion rate or } \\
\text { photorespiration rate }\left(d^{-1}\right) \text {. }\end{array}$ \\
\hline $\operatorname{ARESP}\left(K_{r \mathbf{s}}\right)$ & 0.05 & $\begin{array}{l}\text { Maximum algal dark respiration } \\
\text { rate }\left(d^{-1}\right) \text {. }\end{array}$ \\
\hline ASETL $\left(\omega_{3}\right)$ & 0.07 & $\begin{array}{l}\text { Phytoplankton settling rate } \\
(\mathrm{m} / \mathrm{d}) \text {. }\end{array}$ \\
\hline ASATUR & 20.0 & $\begin{array}{l}\text { Saturation light intensity at } \\
\text { the maximum photosynthetic rate } \\
\left(\mathrm{W} / \mathrm{m}^{2}\right) \text {. }\end{array}$ \\
\hline ALGDET & 0.80 & $\begin{array}{l}\text { Fraction of dead algae which } \\
\text { becomes detritus, the fraction } \\
(1-\text { ALGDET) becomes BOD-L }(-) \text {. }\end{array}$ \\
\hline AGT1 & 0.0 & $\begin{array}{l}\text { Lower temperature bound for } \\
\text { algal growth (C). }\end{array}$ \\
\hline AGT2 & 9.0 & $\begin{array}{l}\text { Lowest temperature at which } \\
\text { growth processes are near the } \\
\text { maximum rate (C). }\end{array}$ \\
\hline AGT3 & 18.0 & $\begin{array}{l}\text { Upper temperature at which } \\
\text { growth processes are near the } \\
\text { maximum rate } \\
\text { (C). }\end{array}$ \\
\hline AGT4 & 30.0 & Upper lethal temperature (C). \\
\hline AGK1 & 0.1 & $\begin{array}{l}\text { Temperature rate multiplier for } \\
\text { AGT1. }\end{array}$ \\
\hline AGK2 & 0.98 & $\begin{array}{l}\text { Temperature rate multiplier for } \\
\text { AGT2. }\end{array}$ \\
\hline AGK3 & 0.98 & $\begin{array}{l}\text { Temperature rate multiplier for } \\
\text { AGT3. }\end{array}$ \\
\hline AGK4 & 0.1 & $\begin{array}{l}\text { Temperature rate multiplier for } \\
\text { AGT } 4 \text {. }\end{array}$ \\
\hline
\end{tabular}


TABLE I

HAGG LAKE CALIBRATED COEFFICIENT VALUES

(continued)

\begin{tabular}{|c|c|c|}
\hline $\begin{array}{l}\text { COEFFICIENT } \\
\text { (Variable in } \\
\text { source/sink } \\
\text { Term in } \\
\text { Appendix A): }\end{array}$ & $\begin{array}{l}\text { HAGG } \\
\text { LARE } \\
\text { MODEL } \\
\text { VALUE: }\end{array}$ & DEFINITION: \\
\hline LABDK $\left(K_{d}\right)$ & 0.05 & Liable DOM decay rate $\left(d^{-1}\right)$. \\
\hline LRFDK $\left(K_{t}\right)$ & 0.001 & $\begin{array}{l}\text { Transfer rate from liable to } \\
\text { refractory DOM }\left(d^{-1}\right) \text {. }\end{array}$ \\
\hline REFDK $\left(K_{r}\right)$ & 0.001 & Refractory DoM decay rate $\left(d^{-1}\right)$. \\
\hline DETDK $\left(\mathrm{K}_{\mathrm{dt}}\right)$ & 0.02 & Detritus decay rate $\left(d^{-1}\right)$. \\
\hline DSETL $\left(\omega_{2}\right)$ & 0.50 & $\begin{array}{l}\text { Detrital settling velocity } \\
(\mathrm{m} / \mathrm{d}) \text {. }\end{array}$ \\
\hline OMT1 & 4.0 & $\begin{array}{l}\text { Lower temperature bound for } \\
\text { organic decomposition }(C) \text {. }\end{array}$ \\
\hline OMT2 & 25.0 & $\begin{array}{l}\text { Temperature where organic } \\
\text { decomposition is near maximum } \\
\text { (C). }\end{array}$ \\
\hline OMK1 & 0.1 & $\begin{array}{l}\text { Temperature rate multiplier for } \\
\text { OMT1. }\end{array}$ \\
\hline OMK2 & 0.98 & $\begin{array}{l}\text { Temperature rate multiplier for } \\
\text { OMT2. }\end{array}$ \\
\hline $\operatorname{SEDDK}\left(\mathrm{K}_{\mathbf{s}}\right)$ & 0.06 & $\begin{array}{l}\text { Sediment decomposition rate }\left(\mathrm{d}^{-}\right. \\
\text {1). }\end{array}$ \\
\hline SOD $\left(X_{1}\right)$ & 0.30 & $\begin{array}{l}\text { Maximum rate of sediment oxygen } \\
\text { demand }\left(\mathrm{g} / \mathrm{m}^{2} / \text { day }\right) .\end{array}$ \\
\hline KBOD & $\begin{array}{l}\text { not } \\
\text { used }\end{array}$ & Decay rate for CBOD $\left(d^{-1}\right)$. \\
\hline TBOD & $\begin{array}{l}\text { not } \\
\text { used }\end{array}$ & $\begin{array}{l}\text { Temperature coef. for CBOD decay } \\
\text { rate correction. }\end{array}$ \\
\hline RBOD & $\begin{array}{l}\text { not } \\
\text { used }\end{array}$ & $\begin{array}{l}\text { Decay rate for } 02 \text { consumption of } \\
\text { CBOD }\left(d^{-1}\right) \text {. }\end{array}$ \\
\hline PO4REL $\left(X_{2}\right)$ & 0.015 & $\begin{array}{l}\text { Rate as fraction of SOD which } \mathrm{PO}_{4} \\
\text { is released from sediments } \\
\text { during anaerobic conditions } \\
\left(\mathrm{g} / \mathrm{m}^{2} / \text { day }\right) \text {. }\end{array}$ \\
\hline
\end{tabular}


TABLE I

HAGG LAKE CALIBRATED COEFFICIENT VALUES (continued)

\begin{tabular}{|c|c|c|}
\hline $\begin{array}{l}\text { COEFFICIENT } \\
\text { (Variable in } \\
\text { source/sink } \\
\text { Term in } \\
\text { Appendix A): }\end{array}$ & $\begin{array}{l}\text { HAGG } \\
\text { LARE } \\
\text { MODEL } \\
\text { VALUE: }\end{array}$ & DEFINITION: \\
\hline $\operatorname{PARTP}\left(\mathrm{A}_{2}\right)$ & 0.005 & $\begin{array}{l}\text { Maximum amount of } \mathrm{PO}_{4} \text { absorbed } \\
\text { per gram of solids }(9 \mathrm{P} \mathrm{m} / \mathrm{g} \\
\left.\text { solid m }{ }^{3}\right) \text {. }\end{array}$ \\
\hline AHSP $\left(A_{1}\right)$ & 0.002 & $\begin{array}{l}\text { Adsorption coef. of } \mathrm{PO}_{4} \text { for use } \\
\text { in the Langmuir isotherm }\left(\mathrm{m}^{3} / \mathrm{g}\right) \text {. }\end{array}$ \\
\hline NH3REL $\left(X_{3}\right)$ & 0.08 & $\begin{array}{l}\text { Rate as fraction of SOD which } \mathrm{NH}_{4} \\
\text { is released from sediments } \\
\text { during anaerobic conditions } \\
\left(\mathrm{g} / \mathrm{m}^{2} / \text { day }\right) \text {. }\end{array}$ \\
\hline NH3DK $\left(K_{a}\right)$ & 0.07 & Ammonia decay rate $\left(\mathrm{d}^{-1}\right)$. \\
\hline PARTN $\left(A_{4}\right)$ & 0.005 & $\begin{array}{l}\text { Maximum amount of } \mathrm{NH}_{3} \text { absorbed } \\
\text { per gram of solids }(\mathrm{g} \mathrm{N} \mathrm{m} / \mathrm{g} \\
\left.\text { solid } \mathrm{m}^{3}\right) \text {. }\end{array}$ \\
\hline AHSN $\left(A_{3}\right)$ & 0.007 & $\begin{array}{l}\text { Adsorption coef. of } \mathrm{N} \text { for use in } \\
\text { the Langmuir isotherm }\left(\mathrm{m}^{3} / \mathrm{g}\right) \text {. }\end{array}$ \\
\hline NH3DT1 & 2.0 & $\begin{array}{l}\text { Lower temp. bound at which } \\
\text { ammonia nitrification continues } \\
\text { (c). }\end{array}$ \\
\hline NH3DT2 & 32.0 & $\begin{array}{l}\text { Lowest temp. at which } \\
\text { nitrification is occurring near } \\
\text { the maximum rate (C). }\end{array}$ \\
\hline NH3K1 & 0.1 & $\begin{array}{l}\text { Temperature rate multiplier for } \\
\text { NH3DT1. }\end{array}$ \\
\hline NH3K2 & 0.98 & $\begin{array}{l}\text { Temperature rate multiplier for } \\
\text { NH3DT2. }\end{array}$ \\
\hline NO3DK $\left(K_{n}\right)$ & 0.20 & $\begin{array}{l}\text { Denitrification rate of the } \\
\text { nitrite plus nitrate-nitrogen } \\
\text { compartment - anaerobic only ( } \mathrm{d}^{-} \\
\text {1). }\end{array}$ \\
\hline NO3DT1 & 2.0 & $\begin{array}{l}\text { Lower temp. bound at which } \\
\text { denitrification continues (C). }\end{array}$ \\
\hline
\end{tabular}


TABLE I

HAGG LAKE CALIBRATED COEFFICIENT VALUES

(continued)

\begin{tabular}{|c|c|c|}
\hline $\begin{array}{l}\text { COEFFICIENT } \\
\text { (Variable in } \\
\text { source/sink } \\
\text { Term in } \\
\text { Appendix A): }\end{array}$ & $\begin{array}{l}\text { HAGG } \\
\text { LAKE } \\
\text { MODEL } \\
\text { VALUE: }\end{array}$ & DEFINITION: \\
\hline NO3DT2 & 20.0 & $\begin{array}{l}\text { Lowest temp. at which } \\
\text { denitrification occurs near } \\
\text { maximum rate }(C) \text {. }\end{array}$ \\
\hline NO3K1 & 0.1 & $\begin{array}{l}\text { Temperature rate multiplier for } \\
\text { NO3DT1. }\end{array}$ \\
\hline NO3K2 & 0.98 & $\begin{array}{l}\text { Temperature rate multiplier for } \\
\text { NO3DT2. }\end{array}$ \\
\hline CO2REL & 0.10 & $\begin{array}{l}\text { Fraction relating sod to } \\
\text { inorganic carbon production }(-) \text {. }\end{array}$ \\
\hline FEREL $\left(X_{4}\right)$ & 0.50 & $\begin{array}{l}\text { Rate as a fraction of SOD which } \\
\mathrm{Fe} \text { is released from sediments } \\
\left(\mathrm{g} / \mathrm{m}^{2} / \text { day }\right) \text {. }\end{array}$ \\
\hline FESETL $\left(\omega_{4}\right)$ & 2.0 & $\begin{array}{l}\text { Rate at which particulate Fe } \\
\text { settles (m/day). }\end{array}$ \\
\hline $\operatorname{ZMAX}\left(\mathrm{K}_{\max }\right)$ & 0.5 & $\begin{array}{l}\text { Maximum ingestion rate for } \\
\text { zooplankton }\left(\mathrm{hr}^{-1}\right) \text {. }\end{array}$ \\
\hline ZMORT $\left(\mathrm{K}_{\mathrm{zm}}\right)$ & 0.001 & $\begin{array}{l}\text { Zooplankton mortality rate }\left(\mathrm{hr}^{-}\right. \\
\left.{ }^{1}\right) .\end{array}$ \\
\hline ZEFFIC $\left(Z_{e}\right)$ & 0.50 & $\begin{array}{l}\text { Zooplankton ingestion efficiency } \\
(-) \text {. }\end{array}$ \\
\hline PREF1 $\left(P_{3}\right)$ & 0.50 & $\begin{array}{l}\text { Preference factor of zooplankton } \\
\text { for algae }(-) \text {. }\end{array}$ \\
\hline PREF2 $\left(P_{3}\right)$ & 0.50 & $\begin{array}{l}\text { Preference factor of zooplankton } \\
\text { for detritus }(-) \text {. }\end{array}$ \\
\hline ZRESP $\left(K_{z r}\right)$ & 0.14 & $\begin{array}{l}\text { Zooplankton respiration rate } \mathrm{hr}^{-} \\
\text {1). }\end{array}$ \\
\hline ZOOMIN $\left(z_{1}\right)$ & 0.01 & $\begin{array}{l}\text { Low threshold concentration for } \\
\text { zooplankton feeding }\left(\mathrm{g} / \mathrm{m}^{3}\right) \text {. }\end{array}$ \\
\hline $\operatorname{ZS} 2 P \quad\left(z_{1 / 2}\right)$ & 0.30 & $\begin{array}{l}\text { Half-saturation coef. for } \\
\text { zooplankton ingestion }\left(\mathrm{g} / \mathrm{m}^{3}\right) \text {. }\end{array}$ \\
\hline
\end{tabular}


TABLE I

HAGG LAKE CALIBRATED COEFFICIENT VALUES (continued)

\begin{tabular}{|c|c|c|}
\hline $\begin{array}{l}\text { COEFFICIENT } \\
\text { (Variable in } \\
\text { source/sink } \\
\text { Term in } \\
\text { Appendix A): }\end{array}$ & $\begin{array}{l}\text { HAGG } \\
\text { LAKE } \\
\text { MODEL } \\
\text { VALUE: }\end{array}$ & DEFINITION: \\
\hline ZOOT1 & 0.0 & $\begin{array}{l}\text { Lower temperature bound for } \\
\text { zooplankton growth } \\
\text { (C). }\end{array}$ \\
\hline ZOOT2 & 20.0 & $\begin{array}{l}\text { Lowest temperature at which } \\
\text { growth processes are near } \\
\text { maximum (C). }\end{array}$ \\
\hline ZOOT3 & 26.0 & $\begin{array}{l}\text { Upper temperature at which } \\
\text { growth processes are near } \\
\text { maximum (C). }\end{array}$ \\
\hline ZOOT4 & 36.0 & $\begin{array}{l}\text { Upper lethal temperature for } \\
\text { zooplankton (C). }\end{array}$ \\
\hline ZOOK1 & 0.1 & $\begin{array}{l}\text { Temperature rate multiplier for } \\
\text { ZOOT1. }\end{array}$ \\
\hline ZOOK2 & 0.98 & $\begin{array}{l}\text { Temperature rate multiplier for } \\
\text { ZooT2. }\end{array}$ \\
\hline ZOOK3 & 0.98 & $\begin{array}{l}\text { Temperature rate multiplier for } \\
\text { zoOT3. }\end{array}$ \\
\hline ZOOK4 & 0.1 & $\begin{array}{l}\text { Temperature rate multiplier for } \\
\text { ZOOT } 4 \text {. }\end{array}$ \\
\hline O2NH3 $\left(\delta_{\text {on }}\right)$ & 4.57 & $\begin{array}{l}\text { Number of grams } \mathrm{O}_{2} \text { reqd. to } \\
\text { oxidize } 1 \mathrm{~g} \text { of } \mathrm{NH}_{4} \text { to } \mathrm{NO}_{3} \text {. }\end{array}$ \\
\hline O2ORG $\left(\delta_{\mathrm{om}}\right)$ & 1.4 & $\begin{array}{l}\text { Stoichiometric requirement for } \mathrm{O}_{2} \\
\text { to decompose organics }(-) \text {. }\end{array}$ \\
\hline O2RESP $\left(\delta_{\text {OZ }}\right)$ & 0.6 & $\begin{array}{l}\mathrm{O}_{2} \text { requirement for biological } \\
\text { respiration }(-) \text {. }\end{array}$ \\
\hline O2ALG $\left(\delta_{\text {of }}\right)$ & 1.4 & $\begin{array}{l}\text { Stoichiometric equivalent for } \mathrm{O}_{2} \\
\text { production during photosynthesis } \\
(-) \text {. }\end{array}$ \\
\hline BIOP $\left(\delta_{p}\right)$ & 0.005 & $\begin{array}{l}\text { Stoichiometric equivalent } \\
\text { between organic matter and } \\
\text { orthophosphate }(-) \text {. }\end{array}$ \\
\hline
\end{tabular}


TABLE I

HAGG LAKE CALIBRATED COEFFICIENT VALUES

(continued)

\begin{tabular}{||l|l|l||}
\hline $\begin{array}{l}\text { COEFFICIENT } \\
\text { Source/sink } \\
\text { Term in } \\
\text { Appendix A): }\end{array}$ & $\begin{array}{l}\text { HAGG } \\
\text { MARE } \\
\text { VALUE: }\end{array}$ & DEFINITION: \\
\hline BION $\left(\delta_{\mathrm{n}}\right)$ & 0.08 & $\begin{array}{l}\text { Stoichiometric equivalent } \\
\text { between organic matter and } \\
\text { nitrogen (-) }\end{array}$ \\
\hline BIOC $\left(\delta_{\mathrm{c}}\right)$ & 0.45 & $\begin{array}{l}\text { Stoichiometric equivalent } \\
\text { between organic matter and } \\
\text { carbon (-) }\end{array}$ \\
\hline O2LIM & 0.50 & $\begin{array}{l}\text { Dissolved }{ }_{2} \text { concentration which } \\
\text { triggers anaerobic conditions } \\
\text { (mg/l) }\end{array}$ \\
\hline FRACT1 & 0.3333 & $\begin{array}{l}\text { Fraction of outflow and } \\
\text { proportion of constituent from } \\
\text { vertical cell 14 (-) }\end{array}$ \\
\hline FRACT2 & 0.4034 & $\begin{array}{l}\text { Fraction of outflow and } \\
\text { proportion of constituent from } \\
\text { vertical cell 15 (-) }\end{array}$ \\
\hline
\end{tabular}

HAGG LAKE CALIBRATION CONCLUSIONS

In order to calibrate a model as complex as CE-QUAL-W2, one would like to have as much historical water quality data on the water body being studied as possible. However, for most water bodies, including Hagg Lake, little water quality data exist. The calibration results show that the exact water quality dynamics were not captured, but the major processes were. Of the seven parameters with U.S.A. field data, model 
simulations of ortho-phosphorus were the most difficult to correlate with U.S.A. ortho-phosphorus data. However, U.S.A. ortho-phosphorus data for the verification year (1991) were much different than the data for the calibration year (1990). Good correlations existed between the calibration year and the verification year for the other six parameters with U.S.A. field data. Hence, there may be further uncertainty in the field data for ortho-phosphorus.

Since Hagg Lake is a reservoir with little inflow during the summer months, calibration of a summer season for this lake was highly dependent on initial conditions. If more time were available and more data were available, a long term run (i.e., 2 years) would be desirable in order to establish the initial conditions for this lake. In addition to this, more parameters could be added to the model to further capture the dynamics of this lake. For instance, the algal compartment could be changed to allow for more than one population to grow in the reservoir at different times during the year. 
CHAPTER VI

\section{HAGG LAKE VERIFICATION}

\section{INTRODUCTION}

Verification refers to the process of taking the calibrated model, and without changing any of the model coefficients, running the model for a different time period and comparing model predictions to field data. If results of this verification period are in similar agreement with model output, the model is said to be "verified". The verification process is performed to further prove the reliability of the model to produce output which is a reflection of the processes of the actual water body.

The Hagg Lake model was run for the verification period of 1991. Once again the model was run from May 1st through october 31st. The only changes that were made for the verification run were changes in initial conditions. Before the verification run could be started, initial water temperature and dissolved oxygen profiles were estimated. As outlined before, these profiles were estimated by setting the initial temperature equal to $6^{\circ} \mathrm{C}$ and the initial D.O. to saturation at $6^{\circ} \mathrm{C}$, equal to $12.45 \mathrm{mg} / \mathrm{l}$ D.O. (Thomann \& Mueller, 1987) throughout the lake on March 1st. The model was run from March 1st to May 1st of 1991. The other changes 
to initial concentrations were made by reviewing the 1991 U.S.A. data on Scoggins creek. Water quality contituents with U.S.A. data on Scoggins Creek were ortho-phosphorous, temperature, ammonia-N, nitrate-N, TDS, TSS, and $\mathrm{pH}$.

\section{VERIFICATION OF HYDRAULICS}

The model hydraulics were again verified first.

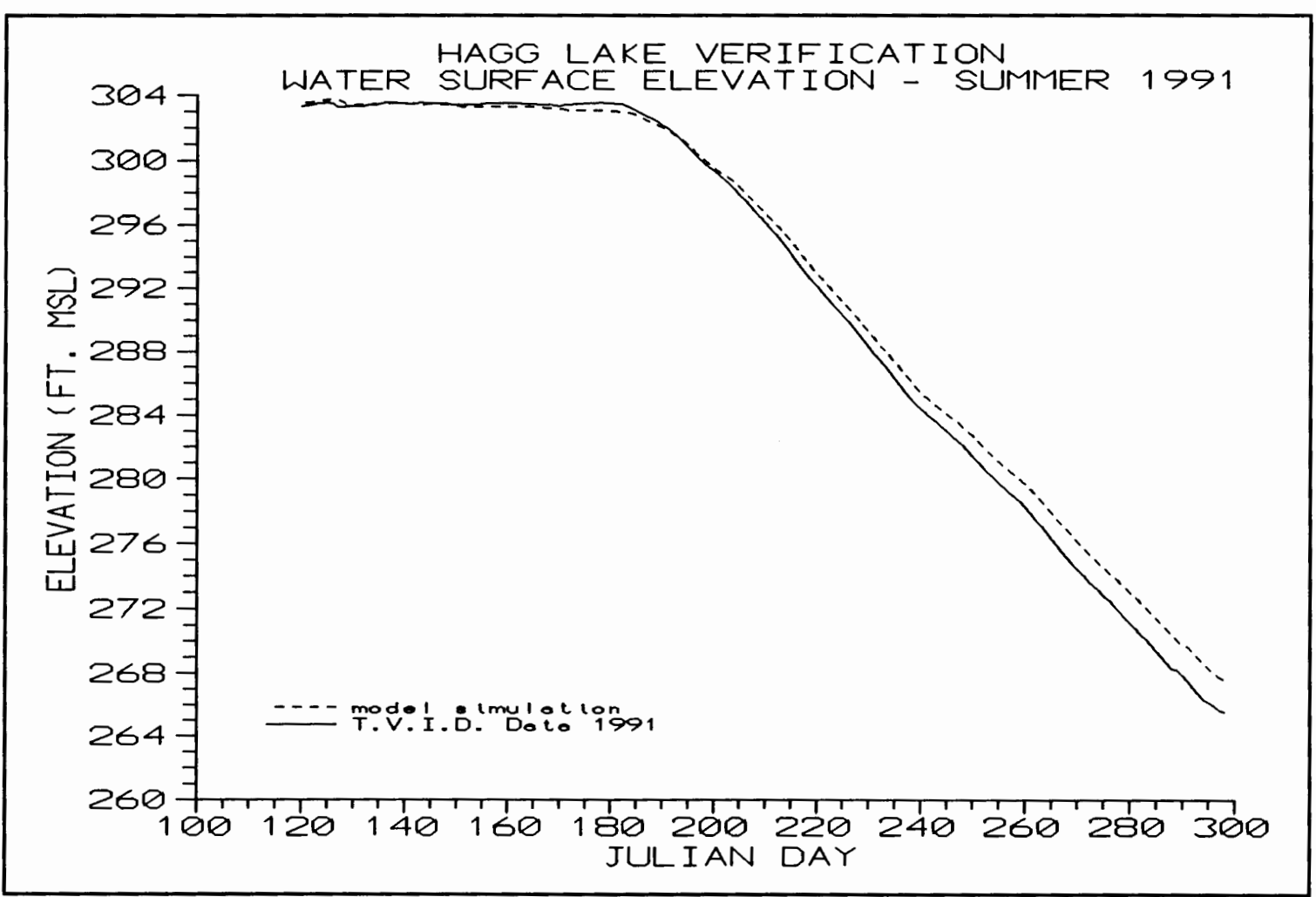

Figure 21. Water surface Elevation simulation versus actual for verification year 1991.

Figure 19 shows that the water surface elevation during the verification period performed well. The model simulation run diverged from the actual water surface elevation at an 
approximately continuous rate, and at the end of the simulation was about 2 feet higher than actual. This divergence occurred also during the calibration run and was thought to be caused by inconsistent bathymetries between the model and the lake.

\section{VERIFICATION OF WATER QUALITY}

The following three figures $(22,23$, and 24) contain graphs of water quality constituents from the verification run versus the 1991 U.S.A. data on Scoggins creek. As one can see, only seven water quality constituents (PO4-P, temperature, NH3-N, NO3-N, TDS, TSS, and pH) had U.S.A. field data available for verification. 


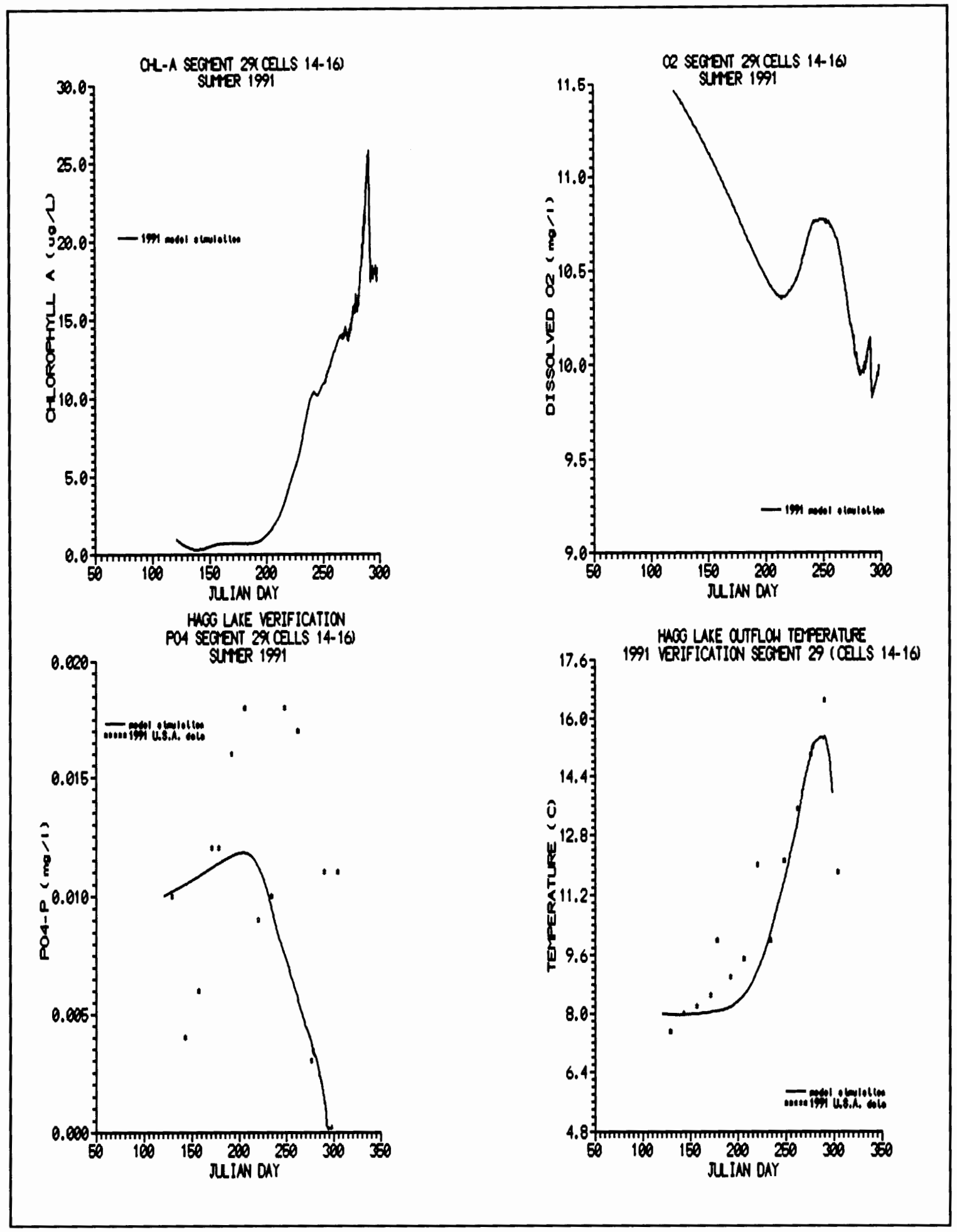

Figure 22. Verification of Chlorophyll-a, $\mathrm{O}_{2}, \mathrm{PO}_{4}-$ $P$, and Temperature, summer 1991. 


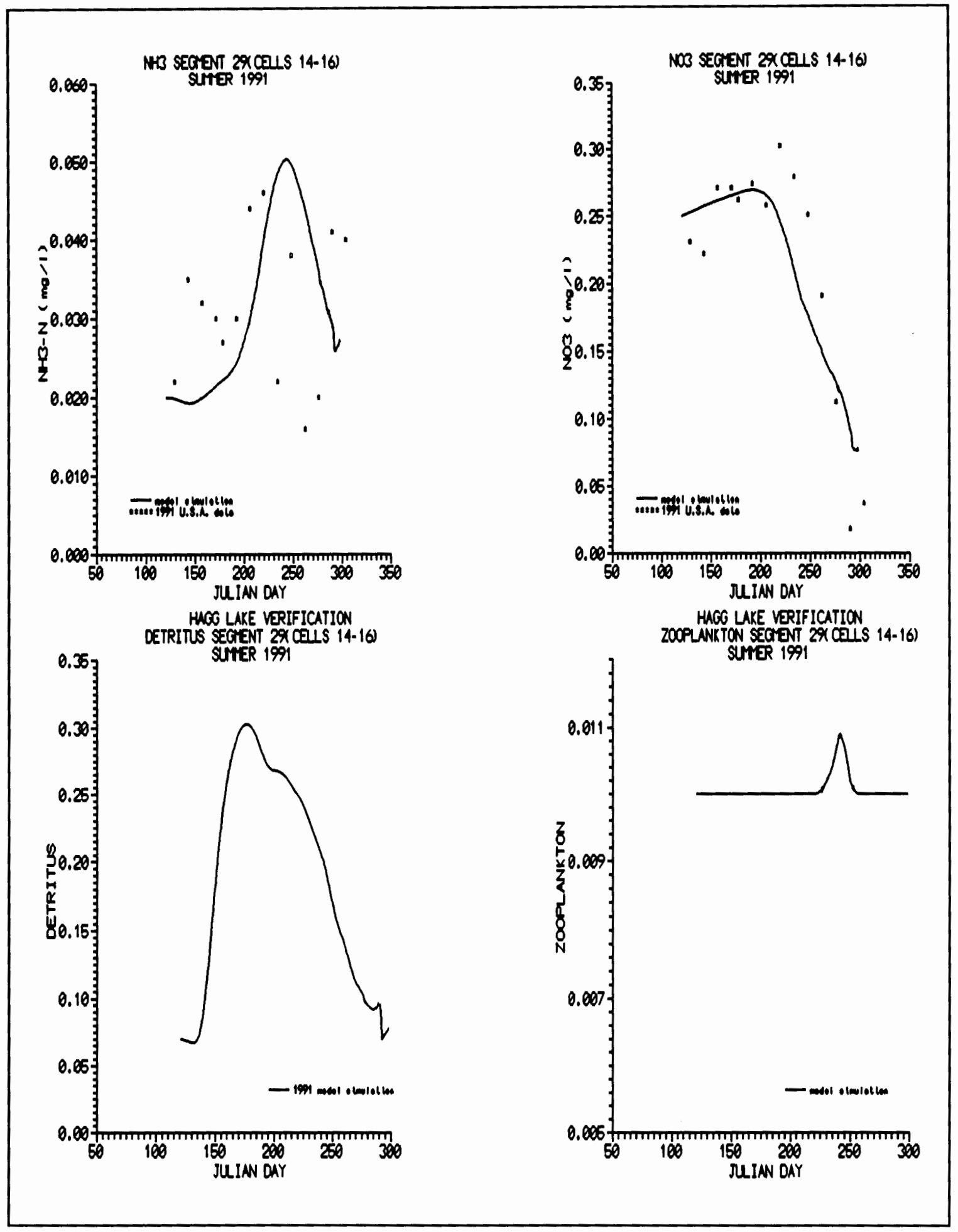

Figure 23. Verification of $\mathrm{NH}_{3}-\mathrm{N}, \mathrm{NO}_{3}-\mathrm{N}$, Detritus, and Zooplankton, for summer of 1991. 


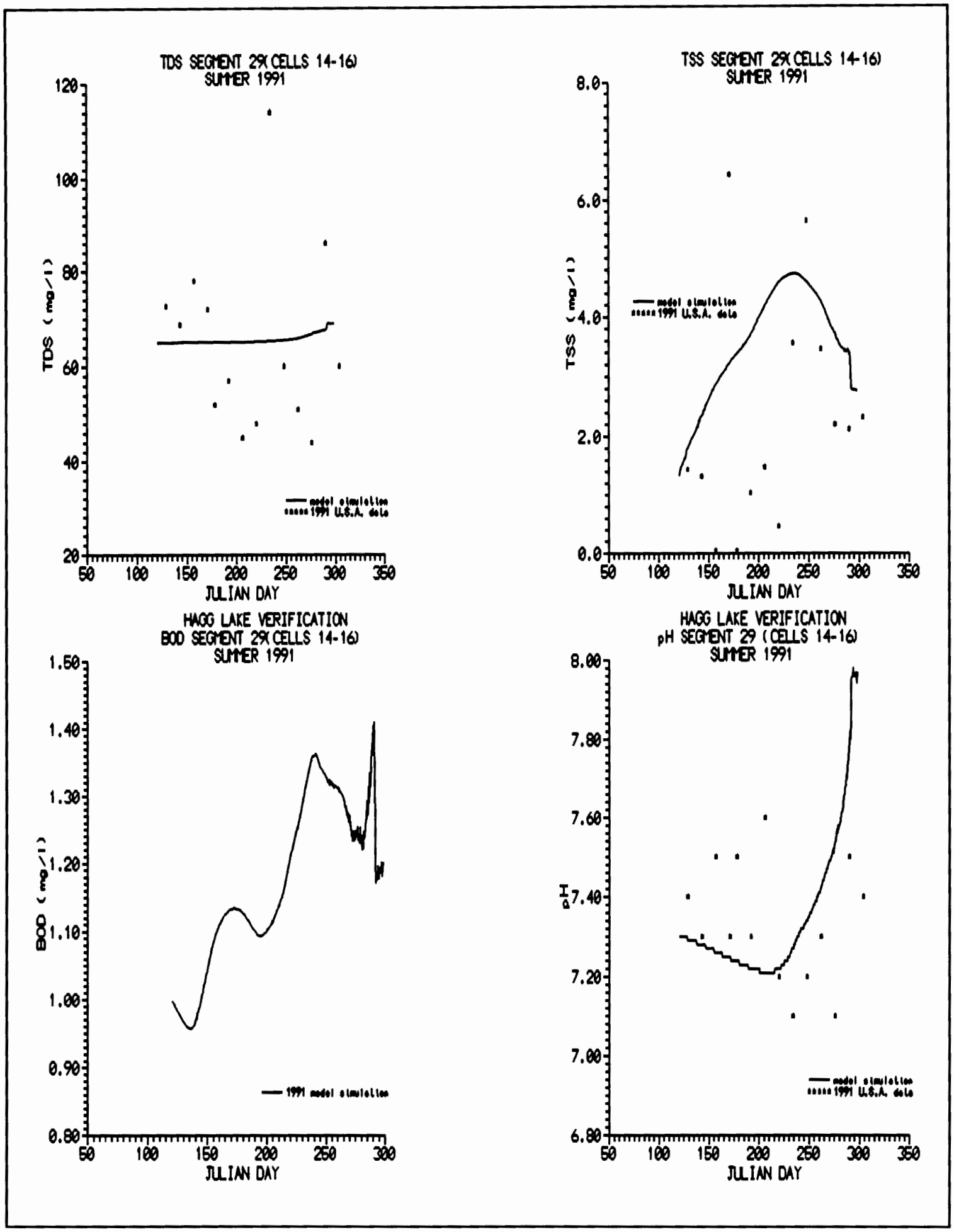

Figure 24. Verification of TDS, TSS, BOD-U, and $\mathrm{pH}$ for summer of 1991. 
From Figures 22 through 24 , the verification run was similar to the results obtained for the calibration run. U.S.A. data on Scoggins creek for 1991 was very similar to the 1990 data for most parameters. The only parameters which had significant differences were $\mathrm{PO}_{4}-\mathrm{P}$, temperature, and TSS. Algal growth was $\mathrm{PO}_{4}-\mathrm{P}$ limited for nearly the entire verification period due to low $\mathrm{PO}_{4}-\mathrm{P}$ concentrations in the lake. Differences in ortho-phosphorus from 1990 to 1991 were discussed earlier, and these differences may be related to measurement error. Since the reported ortho-phosphorus levels were so low in 1990, exact measurements of $\mathrm{PO}_{4}-\mathrm{P}$ concentrations at that low of level would be very difficult. The temperature of outflow in 1991 was higher in 1991 than in 1990. Results of the temperature verification run show that the dynamics of the temperature curve were captured, but the peak value was not (off by approximately $1^{\circ} \mathrm{C}$ ). The TSS data for 1991 were more scattered than in 1990, and verification results showed that the model did not capture the dynamics of TSS in 1991. However, model predictions of TSS are not as accurate as they could be, and as shown in Chapter VIII steps were taken to refine calculations of inorganic suspended solids. Verification results of other constituents were very good, and reflected the calibration results. 


\section{VERIFICATION CONCLUSIONS}

Output for three of the seven (temperature, $\mathrm{NO}_{3}$, and TDS) water quality parameters with U.S.A. data on Scoggins creek showed good agreement between the model and the data. This was especially true for temperature. The model again predicted a well defined epilimnion, thermocline, and hypolimnion. The model also showed reasonable agreement with the data for hydraulics. Much of the dynamics of water quality in Henry Hagg Lake would be better understood if dynamic data were available within this lake. With the limited data set, firm conclusions about the validity of the entire model would require further field data. 
CHAPTER VII

ADDITIONAL FLOW ALTERNATIVE

\section{INTRODUCTION}

once a model has been calibrated and verified with data, the model can be used as a management tool to predict the outcome of man made or natural changes to a water body. This chapter reviews the first management alternative the Hagg Lake model was subject to.

As the FWPCA predicted back in 1967, the water quality of the Tualatin River today is considered poor. The river is not meeting state standards for water quality, and the oregon State Department of Environmental quality is looking at ways to improve the quality of this river. One management alternative proposed, is to further increase the flow in the summer. The source of this extra water is undetermined, but may entail increasing the outflow of Hagg Lake during low flow conditions.

The Hagg Lake model was run for the summer of the calibration year, 1990, with an additional 100 cfs outflow from June 15th through september 15th (the "dry season"). 


\section{LAKE WATER QUALITY VIOLATION ANALYSIS}

A water quality analysis was performed for three key parameters: dissolved oxygen (D.O.), $\mathrm{pH}$, and algae concentrations (measured as chlorophyll-a concentration). Water quality criteria or goals for these parameters were itemized in Table II. Hence, a surface water body would be in violation of a Oregon state Water Quality Goal if it failed to meet one of the criteria shown in Table II at any point in time or space.

TABLE II

WATER QUALITY GOALS FOR DISSOLVED OXYGEN, pH, AND CHLOROPHYLL-a IN HAGG LAKE

\begin{tabular}{||l|c|}
\hline PARAMETER & WATER QUALITY GOAL \\
\hline Dissolved Oxygen & $>6.0 \mathrm{mg} / 1$ \\
\hline Chlorophyll-a & $<15 \mu \mathrm{g} / 1$ \\
\hline $\mathrm{pH}$ & $<8.5$ \\
\hline
\end{tabular}

To determine how Hagg Lake was performing with respect to the water quality criteria, a subroutine was placed in the CEQUAL-W2 code that flagged cells that were not in compliance with these criteria. During the model simulation, the subroutine scanned all cells in Hagg Lake every 30 seconds and recorded the number of and concentrations of any cells not meeting any of these criteria. At the end of the simulation, the number of cells within a specified range of "violation" were summed. These statistics were placed in a bar graph to 
show the magnitude and range of violation for the lake. Equation 12 shows how the model calculated a violation for each water quality goal.

$$
\frac{\sum_{i=1}^{N I T}\left[\sum_{n=1}^{N C E L L S_{i}} N_{n_{j}}\right] \Delta t_{i}\left(\frac{1}{N C E L L S_{i}}\right)}{T}
$$

Where:

$$
\begin{array}{ll}
\mathrm{NIT} & =\text { \# of time steps } \\
\mathbf{i} & =\text { time step number } \\
\mathrm{NCELLS}_{i} & =\text { number of model cells at time step } \\
\mathrm{n} & =\text { cell number } \\
\mathrm{N}_{j} & =\text { number of violations at interval } j \\
\Delta t & =\text { model time step (30 sec) } \\
\mathrm{T} & =\text { simulation time period } \\
j & =\text { range of violation for histograms }
\end{array}
$$

An "average violation" was computed for each of the three parameters. This "average violation" was computed at the end of a simulation and was the result of multiplying the magnitude of a given violation by the time step during this violation, summing all of these factors (violation times time step) for the entire simulation, and dividing this number by the total simulation time. This calculation yielded an average number of cells that would be in a particular violation range at any given time. The number of active cells was also calculated every 30 seconds, and the number of cells in violation for any given parameter was divided by the active cells to determine a percentage of active cells in violation. Thus, these "violations" represent the average percentage of 
active cells in violation in the lake at any point during the simulation period.

The following six figures show histograms which compare violations for the three critical parameters mentioned above for the base case and the additional flow alternative. Figures 25 and 26 contain histograms of the dissolved oxygen violations for the base case and the additional flow alternative, respectively. Figures 27 and 28 contain histograms of the $\mathrm{pH}$ violations and Figures 29 and 30 contain histograms of the chlorophyll-a violations. Since these six plots do not show how water quality would change for all aspects of the lake, including how downstream water quality would be impacted, graphs of outflow water quality were also made. Figures 31 and 32 contain plots of temperature, water surface elevation, $\mathrm{pH}$, chlorophyll-a concentration, dissolved oxygen concentration, ortho-phosphorus concentration, nitrate$N$ concentration, and ammonia-N concentrations coming out the outlet during the base case and the additional flow alternative. 
BASE CASE - DISS. OXYGEN

Hagg Lake Simulation

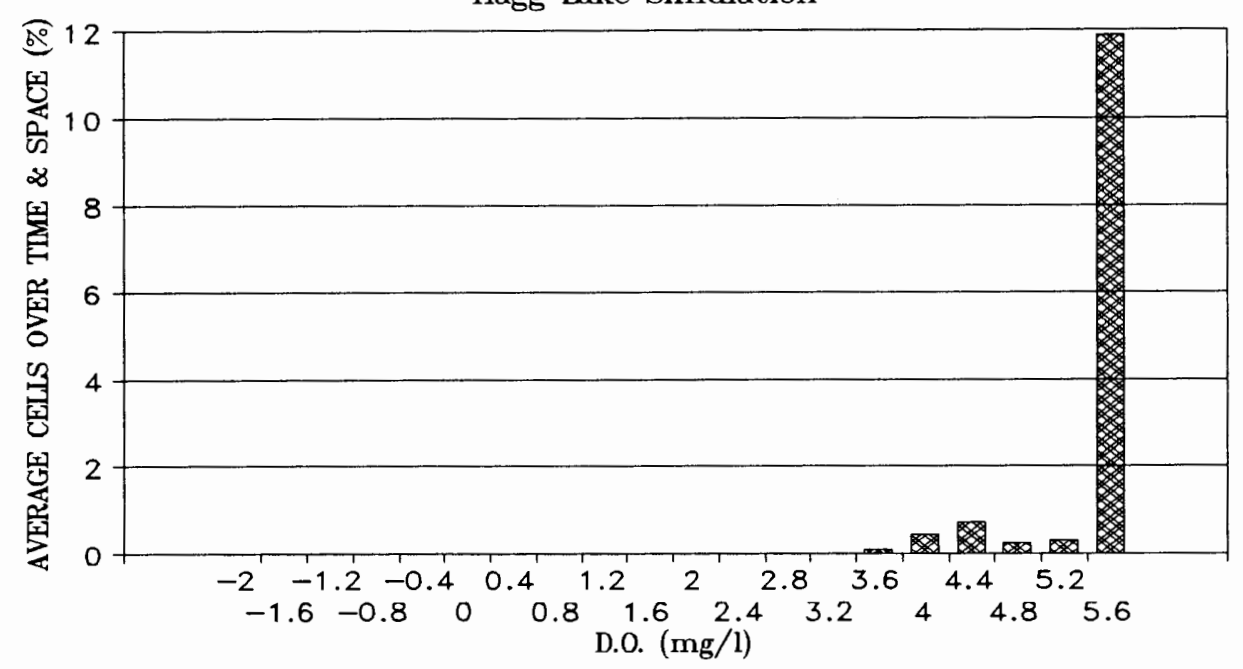

Figure 25. Base Case for Hagg Lake Dissolved Oxygen violations summer of 1990 (Average violation $=5.35 \mathrm{mg} / \mathrm{ll}$ ).

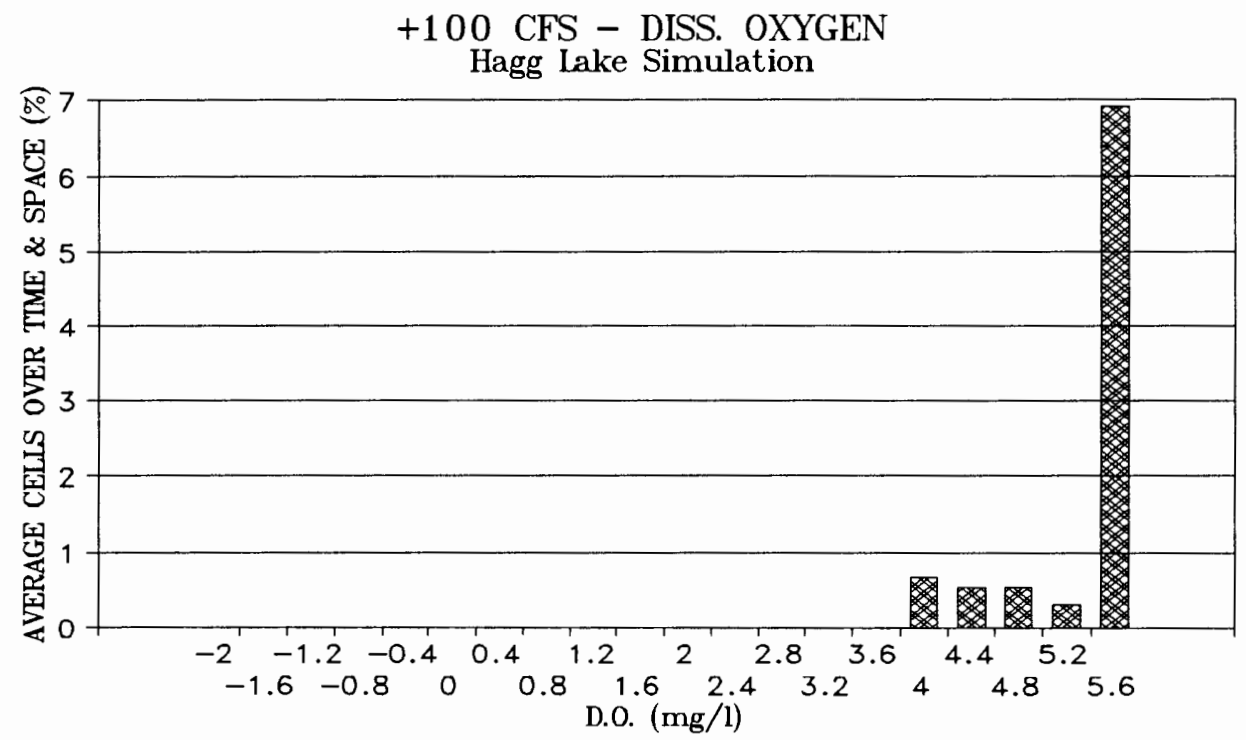

Figure 26. Dissolved oxygen violations with additional 100 cfs outflow from 6/15 through 9/15 1990 (Average violation $=5.12 \mathrm{mg} / \mathrm{l}$ ). 
BASE CASE - pH

Hagg Lake Simulation

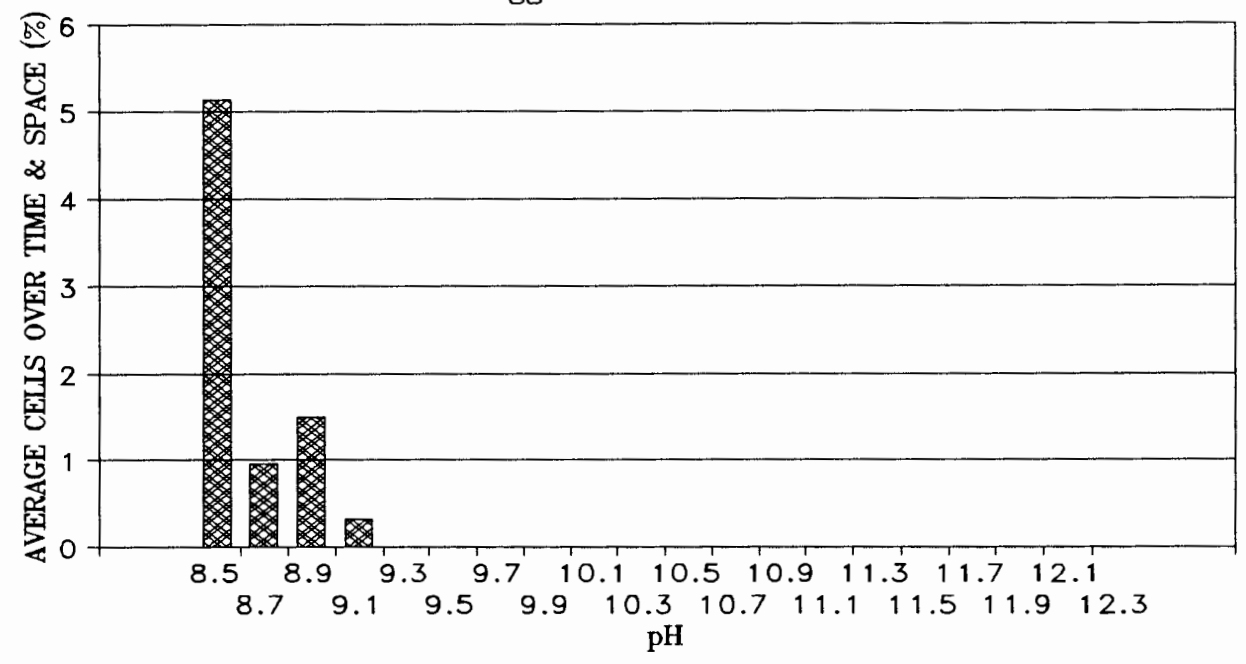

Figure 27. Base Case for Hagg Lake pH violations, for the summer of 1990 (Average violation $=8.65$ ).

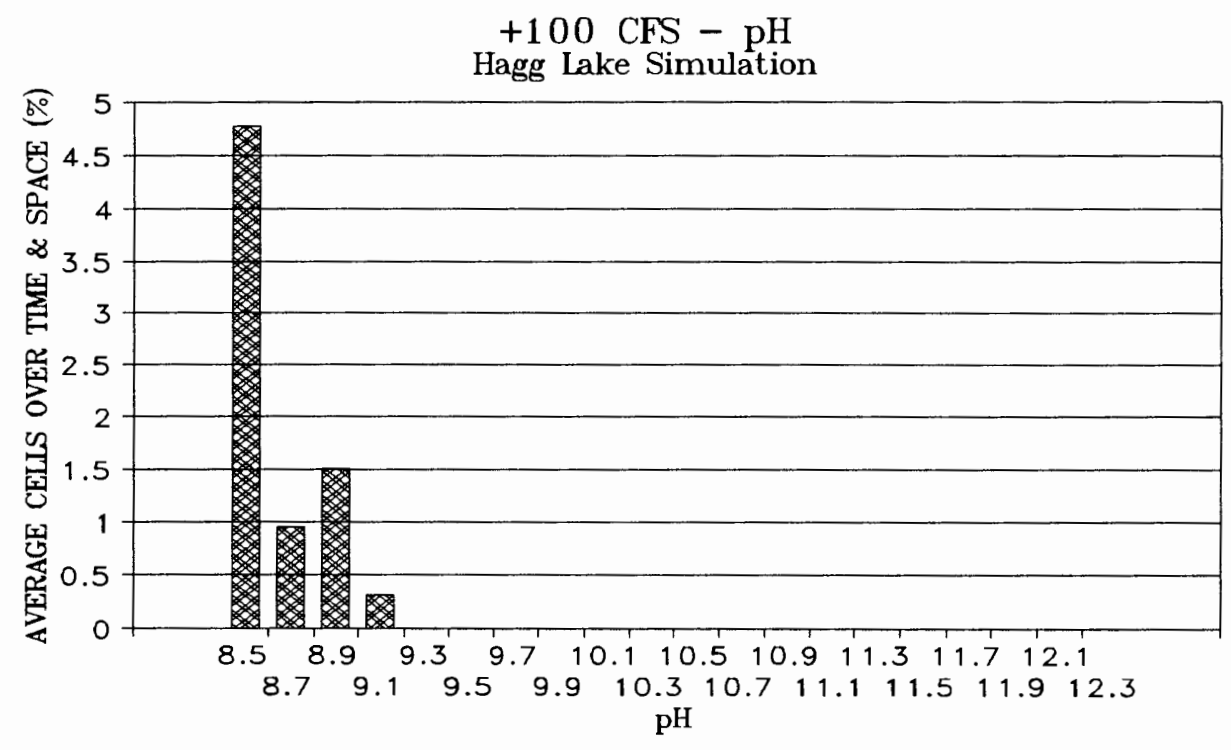

Figure 28. $\mathrm{pH}$ violations base case with $100 \mathrm{cfs}$ additional flow from $6 / 15$ through $9 / 15 \quad 1990$ (Average violation $=8.65)$. 


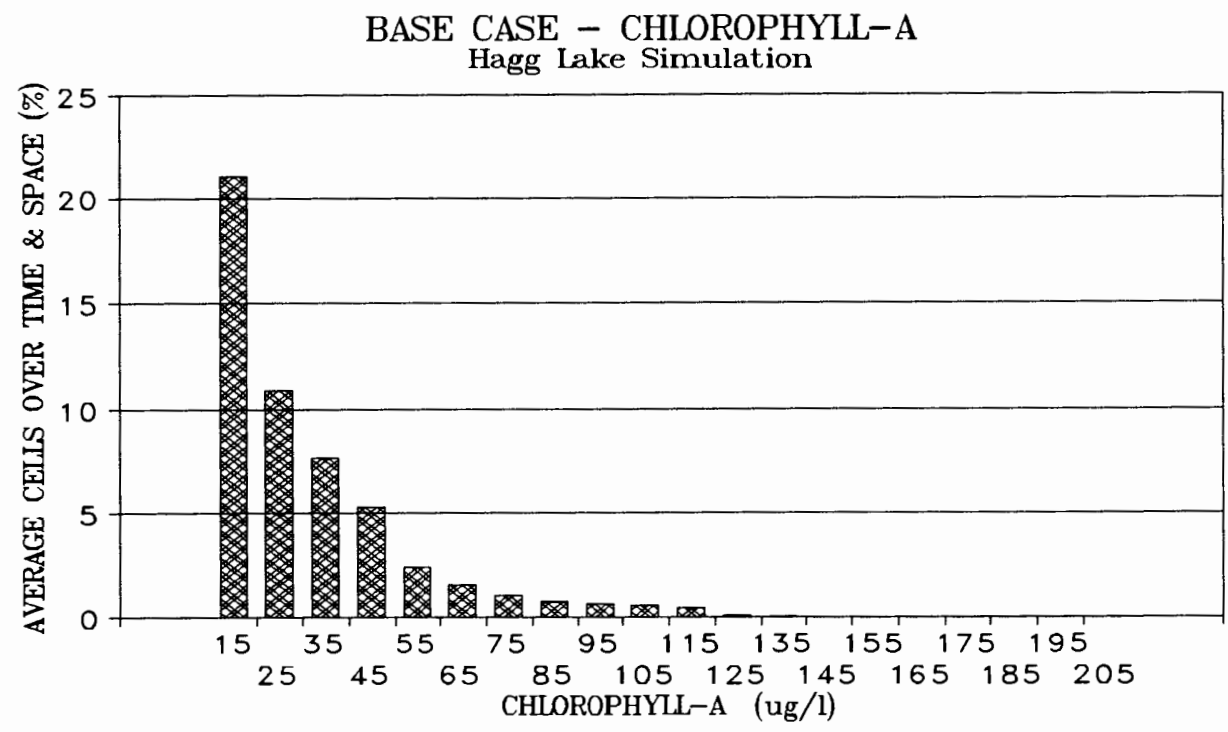

Figure 29. Base Case for Hagg Lake Chlorophyll-A violations, for the summer of 1990 (Average violation $=40.15 \mu \mathrm{g} / \mathrm{I}$ ).

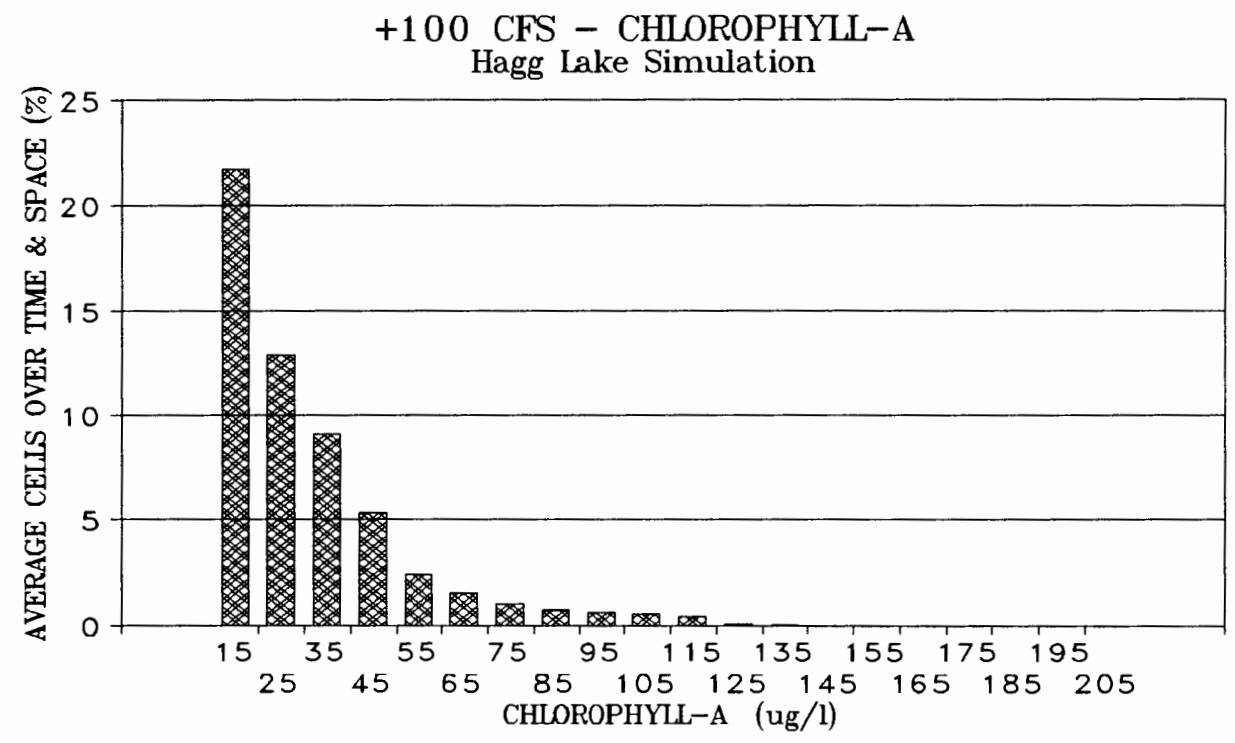

Fiqure 30. Chlorophyll-A violations base case with 100 cfs additional flow from 6/15 through 9/15 1990 (Average violation $=40.65 \mu \mathrm{g} / \mathrm{I}$ ). 
As one can see from Figures 25 through 30, there was little difference between the base case and the additional flow alternative for violation goals. The following three paragraphs summarize the reasoning for the slight differences that occurred between the base case and the additional flow alternative violations.

The base case had slightly better water quality with respect to D.O. One may expect this since the pool level would be lowered causing higher temperatures and greater algal growth, resulting in lower D.O. concentrations for the additional flow case. In both cases, dissolved oxygen in the lake is somewhat stratified due to algal growth, but overall D.O. concentrations are adequate for fish survival.

As for $\mathrm{pH}$, the results of the two simulations were quite similar. The additional flow case had slightly better water quality with respect to $\mathrm{pH}$. This was most likely a result of increased flow, thus, greater mixing in lower layers in the additional flow case. In both cases, the $\mathrm{pH}$ of Hagg Lake was somewhat higher than neutral, but overall very good.

Chlorophyll-a concentrations were very similar for both cases. The number of violations was higher for the additional flow case, but not by much. One would expect the smaller pool for the additional flow case to heat up more than the base case and thus have greater algal blooms than the base case. However, the actual surface area of the top layers decreases as the pool lowers. It is believed that this surface area 
reduction offsets the warmer-lower-pool condition for the additional flow case. Thus, the two cases have similar algal populations.

This exercise in comparing standard violations for the entire lake did not show the differences in outflow water quality, which would be of concern for the Tualatin River. Therefore, Figures 31 and 32 were added to compare outflow water quality for the base case with that from the additional flow alternative. 


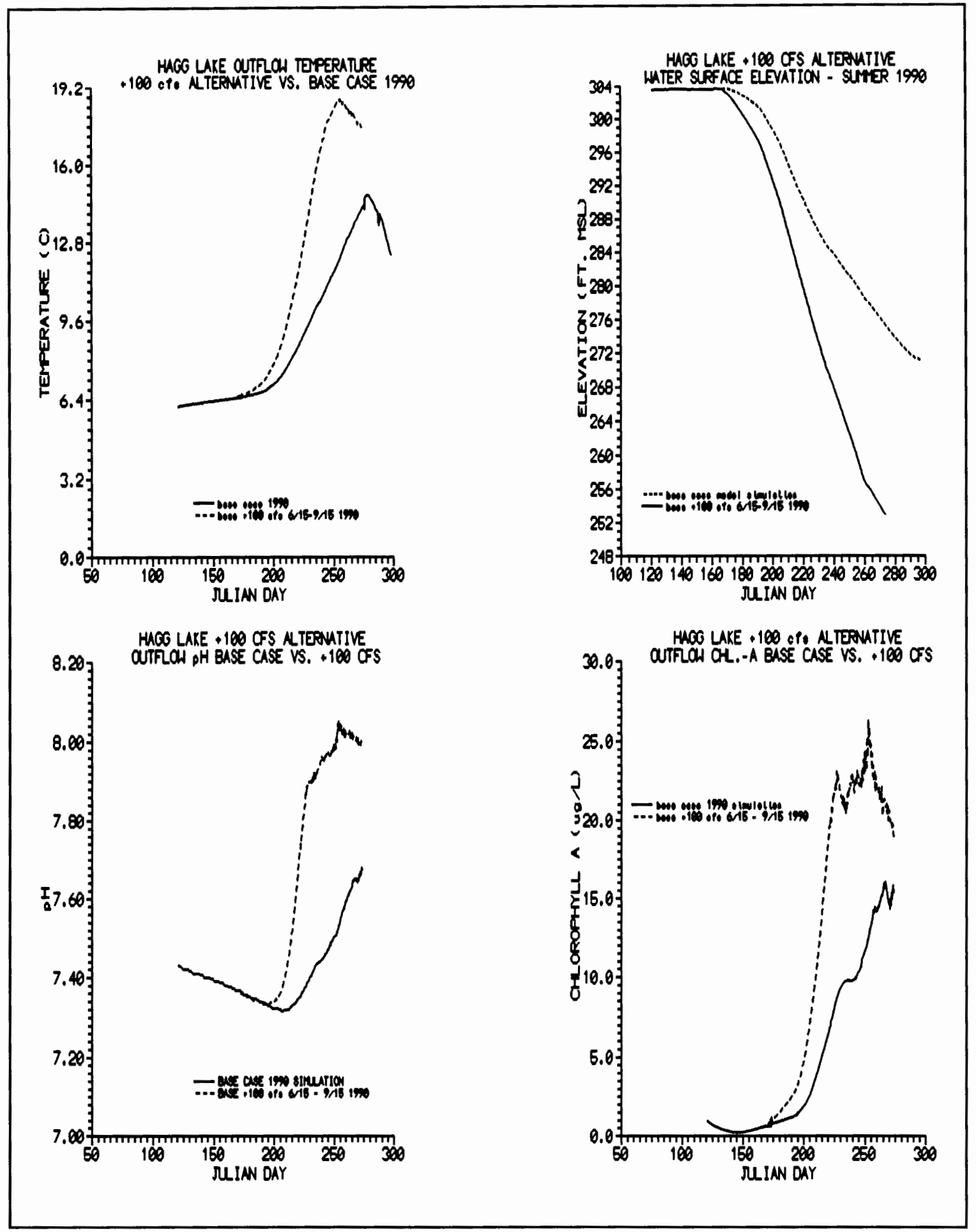

Figure 31. Hagg Lake Outflow Temperature, Water Surface Elevation, $\mathrm{pH}$, and Chlorophyll-a concentration base case 1990 versus base case +100 cfs from 6/15 through 9/15 1990. 
As shown in Figure 31, the outflow temperature increased as expected for the additional flow case. Also, with the decrease in volume, the lag time for temperature transfer from the air to the lake was reduced and the peak temperature was shifted to the left, thus occurring earlier in the season. The water level was reduced from an end-of-period elevation of approximately 276 feet to 253 feet, a difference of 23 feet. Since the top of the outflow intake structure is located at 238 feet M.S.L., there would be ample space for this additional amount of water to be withdrawn during this type of withdrawal season. However, the decreased surface area of the lake would severely affect recreation on the lake. Outflow pH is slightly higher for the additional flow case, and outflow chlorophyll-a concentrations are much greater for the additional flow case. 


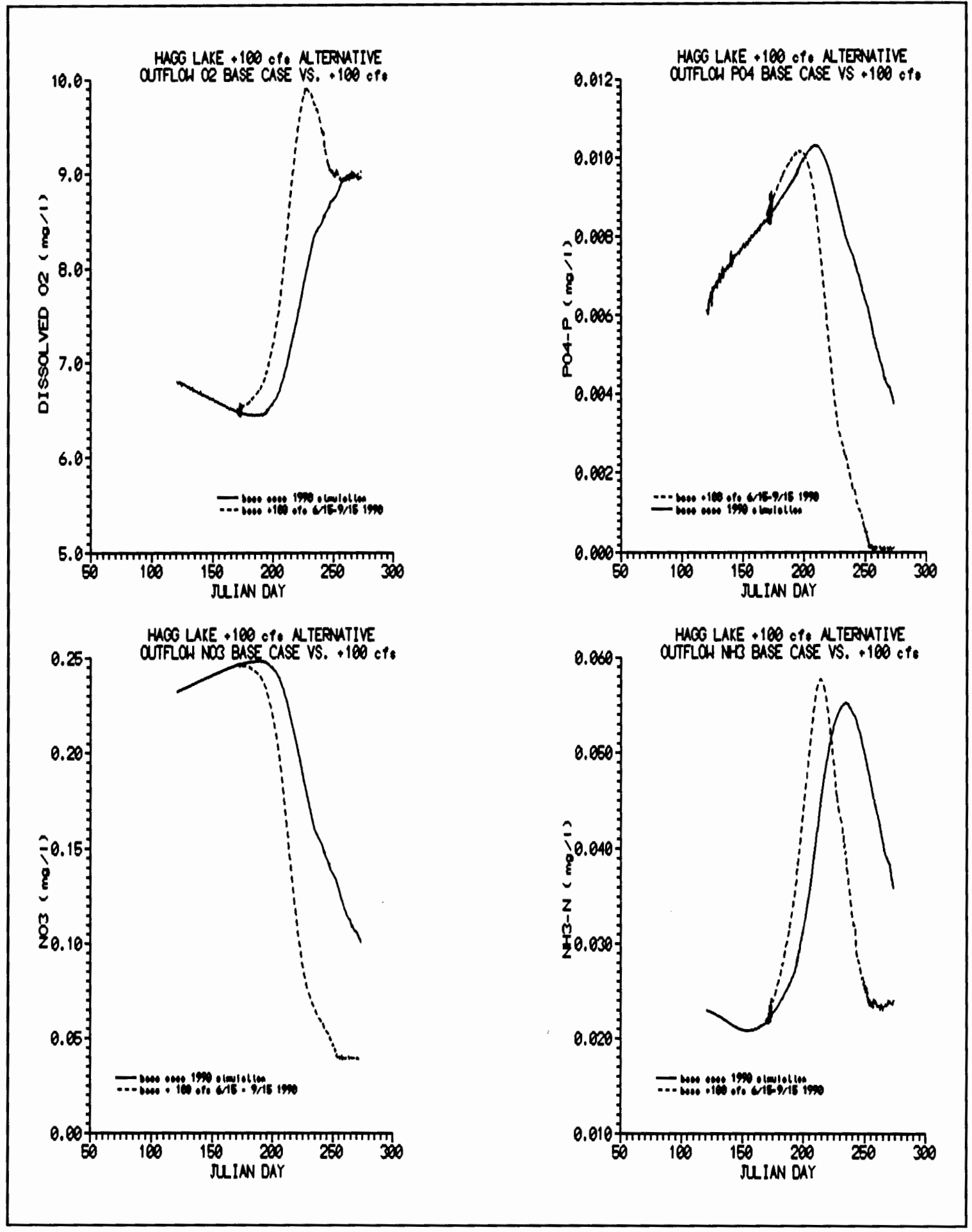

Figure 32. Hagg Lake Outflow Dissolved oxygen, Ortho-phosphorous, $\mathrm{NO}_{3}-\mathrm{N}$, and $\mathrm{NH}_{3}-\mathrm{N}$ Base Case 1990 versus Base Case +100 cfs additional flow from $6 / 15$ through $9 / 151990$. 
As shown in Figure 32, outflow D.O. concentrations are greater for the additional flow case due to increased photosynthesis in the lower layers. The three nutrients that are important for algal growth (ortho-phosphorus, $\mathrm{NO}_{3}-\mathrm{N}$, and $\mathrm{NH}_{3}-\mathrm{N}$ ) show their response to the increased and earlier algal growth in the lower layers. Ortho-phosphorus and $\mathrm{NO}_{3}-\mathrm{N}$ get stripped out earlier from the algal growth, and $\mathrm{NH}_{3}-\mathrm{N}$ dynamics are shifted to the left due to the earlier reduction in pool level followed by algal growth in the lower layers.

This additional flow analysis showed that during a summer season such as 1990, additional flow to the Tualatin River could be supplied by Hagg Lake. The water quality of this additional outflow would be worse than previous outflow, but it may suffice the needs of the Tualatin River. The water quality of Hagg Lake would not be severely affected. However, the lowering of the lake may severely affect boating and other water oriented recreation at this lake. Also, with more shore surface area exposed, problems with scouring of bank sediments may be more important. 
CHAPTER VIII

RESERVOIR SEDIMENTATION ANALYSIS

\section{INTRODUCTION}

The process of damming a natural stream inherently changes the patterns of sediment deposition in that stream. Most natural streams eventually deposit their sediment load at their confluence with a larger river, which in turn carries this sediment in the same process, until finally the sediment is deposited in the ocean. However, the construction of a dam and reservoir on a stream greatly changes this process. Sediments remain suspended in a stream as long as there is enough energy to keep them there. Once this necessary energy is reduced, particles settle out. When a stream flows into a reservoir, its energy is greatly reduced and sedimentation occurs. Furthermore, the clearing of natural vegetation from a reservoir's banks drastically increases the erosive effects of wave action and precipitation at the reservoir site.

The useful life of a reservoir is dependent on many factors: sediment types, inflow, capacity, sediment load, and trap efficiency (Lopez, 1978). Sediments are characterized by their particles. Different soils have differing amounts of three major inorganic particles, namely, sand, silt, and clay. These three particle types are characterized by their sizes, 
with sand having the largest particles (of the three), from $0.0625 \mathrm{~mm}$ to $2.0 \mathrm{~mm}$, silt having the median size range, from $0.004 \mathrm{~mm}$ to $0.625 \mathrm{~mm}$, and clay having the smallest sized particles, less than $0.004 \mathrm{~mm}$ (Lopez, 1978). Besides being a function of soil type, sedimentation in a reservoir is also a function of its watershed: topography, management practices, and hydrology. Sedimentation occurs most rapidly in a reservoir that is small in relation to the river that feeds it (Lopez, 1978). Sedimentation also occurs more rapidly if the river basin in which the reservoir resides has large agricultural runoff or severe logging (Lopez, 1978; Klingeman et.al., 1971). The trap efficiency of a reservoir refers to a reservoir's ability to retain suspended sediments. Many empirical relations (i.e., Borland, 1971; Brune, 1953; etc.) have been proposed to compute the trap efficiency of a reservoir, and they usually relate the percentage of sediments retained to the inflow and the capacity of the reservoir (Lopez, 1978). Generalized trap efficiency curves were developed by Brune (1953) for storage type reservoirs. By taking the ratio of reservoir capacity to mean annual inflow, the trap efficiency may be determined from these curves. Using the 1990 Hagg Lake inflow computed by the Dam operator (T.V.I.D., 1990), a trap efficiency of $95 \%$ was computed for fine sediments for this lake. This means that nearly all sediments settle out in Hagg Lake. When designing a reservoir, engineers must take all of these factors into 
account and decide on the amount of storage that will be allotted for sedimentation. In deciding on a reservoir's sediment storage capacity, they are deciding on how long the reservoir will operate. Once the reservoir fills the allotted sedimentation storage, it may be rendered useless.

When inflow to a reservoir reaches the pool, it begins to lose velocity, hence energy, and the largest particles (i.e., sand and gravel) in the sediment load begin to settle out (Lopez, 1978). This trend continues as the flow loses more energy and silt is eventually deposited further into the pool (Lopez, 1978). Clay particles may remain in the water column, but if the detention time is large enough, they will eventually settle out as well (Lopez, 1978). Therefore, the deposition of sediments in a reservoir will consist of a backwater deposit, a sand and gravel delta, and a bottom deposit of silt and clay (Lopez, 1978). The backwater deposit is that portion of sediment deposited at the stream-reservoir interface, and it may grow both out into the reservoir and back up the stream channel. Stagnant pools combined with rooted plant growth can occur in the backwater areas, resulting in undesirable environmental conditions in the backwater zones (Lopez, 1978). The finest particles may flow through the reservoir as a density current until they enter a slack water condition in which the load is deposited (Lopez, 1978). The bottom sediments have been observed to deposit most everywhere in a reservoir, but mainly in regions of low 
velocity (Lopez, 1978). Very fine clay particles that remain in the water column increase the turbidity of a reservoir which results in unsightly conditions and reduction of light penetration in the reservoir.

In a reservoir, there are two sources of turbidity: the watershed feeding the reservoir and the reservoir's shoreline. Most forested watersheds such as that surrounding Hagg Lake have fairly stable sediments unless altered by man or natural disturbances such as landslides or severe slumping (Klingeman, 1971; Washington County, 1983). When these forests are logged, vast acres of clear-cut tracts and logging road cuts can increase sedimentation in a watershed substantially. Subbasins in the area surrounding Hagg Lake have been logged anywhere from 0 to $50 \%$ (Fromuth, 1992). However, the drainage basin contributing to Hagg Lake is mostly covered by second-growth Douglas Fir, with a few small farms and some open grassland used for grazing (Johnson, et. al., 1985). Therefore, contributions of turbidity to the lake from extensive logging and road cuts are believed to be minimal. Another possible source of turbidity in Hagg Lake could be caused by shoreline sedimentation. There are three possible sources of sediment from a shoreline: erosion and shifting of terraces during raising and lowering of the reservoir pool, sheet and gully erosion of the shore during low pool level periods, and wave action on the banks of the shoreline during normal pool operations (Klingeman, et. al., 1971). From 
observations at Hagg Lake, it appears that all three of these processes are occurring to some degree. However, Klingeman, et. al. (1971) showed, from studies of 12 willamette Valley Reservoirs (excluding Hagg Lake), that the majority of sediments that settled in these reservoirs came from their watersheds, rather than from their banks. These watersheds were in regions of heavy logging activities. which attributed to their sediment loads. It was also shown that most of the sediments came from a few storms during the wet winter months from November to February. A similar study was performed on the Upper Tualatin River by the Washington county soil Conservation service in 1983, they concluded that as much as $75 \%$ of the total yearly sediment load in the Upper Tualatin River could be attributed to 4 to 5 winter storms which lasted approximately $10 \%$ of the total time.

Normal stream sediment transport rates for Northwest Oregon range from 0.1 to 0.2 acre-feet per square mile per year (U.S.D.A.-S.C.S., Dec., 1974). By applying these factors to the Hagg Lake Watershed Area of 37.5 square miles, a normal sediment transport range of 3.75 to 7.5 acre-feet per year is obtained. Since the Hagg Lake Watershed is mostly forested, it would probably have a sedimentation rate in the lower range. However, according to the Scoggins Dam operator, the U.S. Bureau of Reclamation left approximately 6,280 acre-feet of dead storage for sedimentation, based on a 100 year life of this reservoir. This reveals a sediment transport rate of 
62.8 acre-feet per year, 10 times higher than that predicted for "normal Western Oregon streams". Therefore, the Bureau of Reclamation must have been anticipating high erosion to take place in and around Hagg Lake. In order to get an idea of the nature of sedimentation in Hagg Lake, the CE-QUAL-W2 model was adapted to account for various particle sizes.

\section{PARTICLE SIZE DISTRIBUTION ADDITION TO HAGG LAKE MODEL}

As shown in Chapter III, inorganic particles are modeled by CE-QUAL-W2 in one compartment. There are no sources besides inflows from tributaries or distributed tributaries, and sinks are treated by a single settling rate. Besides sedimentation additional sediment transport may be caused by the hydrodynamics of the system (i.e., horizontal and vertical advection). CE-QUAL-W2 bases the settling rate on Stoke's Law for settling velocity (see equation 12). It would be extremely rare to have a soil with only one particle size fraction, and this is a limitation of the model. In order to model a natural soil more accurately, more particle size fractions were included in the model with their respective differing settling rates according to stoke's Law.

According to the Washington County Soil survey (Green, 1982), the Hagg Lake Watershed is overlain with the following sediments: Hembre silt loam, Pervina silty clay loam, Oylic silt loam, Tolke silt loam, and Melbourne silty clay loam. With Melbourne silty clay loam, Pervina silty clay loam, and 
Olyic silt loam being the most extensive. Melbourne silty clay loam lines much of the lake and surrounds the entire lake shore. Since this soil is exposed to all of the shoreline sedimentation processes, this soil was chosen for further analysis. Table III shows the engineering properties of Melbourne silty clay loam (Green, 1982).

\section{TABLE III}

ENGINEERING PROPERTIES OF MELBOURNE SILTY CLAY LOAM Percent Passing Sieve

\begin{tabular}{||l|l|l|l|l|l|l|l||}
\hline Depth & $\begin{array}{l}\text { Class } \\
\text { Unified }\end{array}$ & $\# 4$ & $\# 10$ & $\# 40$ & $\# 200$ & $\begin{array}{l}\text { Liquid } \\
\text { Limit }\end{array}$ & Plasticity \\
\hline $\begin{array}{l}\text { 0"- } \\
18 "\end{array}$ & ML, CL & $\begin{array}{l}95- \\
100\end{array}$ & $\begin{array}{l}95- \\
100\end{array}$ & $\begin{array}{l}95- \\
100\end{array}$ & $\begin{array}{l}75- \\
95\end{array}$ & $35-45$ & $10-20$ \\
\hline $\begin{array}{l}18 "- \\
66 "\end{array}$ & MH, ML & $\begin{array}{l}95- \\
100\end{array}$ & $\begin{array}{l}95- \\
100\end{array}$ & $\begin{array}{l}95- \\
100\end{array}$ & $\begin{array}{l}80- \\
95\end{array}$ & $45-60$ & $10-20$ \\
\hline
\end{tabular}

From the sieve analysis performed on this soil, the soil was made up of mostly clay particles. The Washington county Soil Survey (Green, 1982) classifies this soil in the following family and subgroup: Clayey-Kaolinitic-Mesic-XericHaplohumult. The terms are defined as follows: Clayey is a description of the soil particles; Kaolinitic is the soil class which describes the mineralogy of the soil (greater than $50 \%$ kaolinite); Mesic is the class of soil temperature regime for soils with a mean annual soil temperature of $8^{\circ} \mathrm{C}$ to $15^{\circ} \mathrm{C}$; Xeric is the moisture regime of soils where winters are moist and cool and summers are warm and dry; and Haplohumult is a 
great group of the Utisol class, which further distinguishes different soil types (U.S.D.A.-S.C.S., 1975). Since a more thorough particle size analysis was not found for this soil, particle size analyses of two other soils, similar in nature and belonging to a similar family and subgroup, were used to establish a finer soil particle size fraction for Melbourne silty clay loam. A soil survey of the Yamhill Area (Otte, 1974) had a particle size analysis of Peavine silty clay loam which was performed in a laboratory using the "pipette method". This soil was classed in the family of Clayey-MixedMesic, and in the subgroup of: Typic-Haplohumult. This soil was chosen as a good approximation for the particle size distribution of Melbourne silty clay loam because both soils are categorized as clayey and both are in the group of Haplohumults. In soil classification, the soil class (i.e., clayey) and the soil group (i.e., Haplohumult) distinguish particle sizes of the soil. Therefore, the two soils should have similar particle sizes. Another laboratory analysis was found for a soil from Nevada County, California, and this soil was classified as a Clayey-Kaolinitic-Mesic-Xeric-Haplohumult, which was the same classification as Melbourne Silty Clay Loam (U.S.D.A.-S.C.S., 1975, pp. 712-713). Tables IV and V show the particle size distributions of the two soils chosen for extrapolation to the study area. 
TABLE IV

PARTICLE SIZE DISTRIBUTION OF PEAVINE SILTY CLAY LOAM (Otte, 1974)

\begin{tabular}{||l|l|l|l|l|l|l|l|l|l||}
\hline $\begin{array}{l}\text { Depth } \\
\text { in.) }\end{array}$ & $\begin{array}{l}2-1 \\
\mathrm{~mm}\end{array}$ & $\begin{array}{l}1- \\
.5\end{array}$ & $\begin{array}{l}.5- \\
\mathrm{mm} \\
\mathrm{mm}\end{array}$ & $\begin{array}{l}.25 \\
-.1 \\
\mathrm{~mm}\end{array}$ & $\begin{array}{l}.1- \\
.05 \\
\mathrm{~mm}\end{array}$ & $\begin{array}{l}.05- \\
.002 \\
\mathrm{~mm}\end{array}$ & $\begin{array}{l}<.002 \\
\mathrm{~mm}\end{array}$ & $\begin{array}{l}.2- \\
.02 \\
\mathrm{~mm}\end{array}$ & $\begin{array}{l}.02- \\
.002 \\
\mathrm{~mm}\end{array}$ \\
\hline $0-4$ & .8 & 1.7 & 1.1 & 2.0 & 3.1 & 54.2 & 37.1 & 25.8 & 32.6 \\
\hline $4-10$ & .5 & 1.3 & 1.0 & 1.9 & 3.5 & 55.6 & 36.2 & 25.7 & 34.3 \\
\hline $10-15$ & .2 & .7 & .7 & 1.2 & 2.2 & 43.0 & 52.0 & 18.9 & 27.0 \\
\hline $15-26$ & .2 & .4 & .3 & .7 & 2.1 & 29.5 & 66.8 & 8.6 & 23.4 \\
\hline $26-36$ & .1 & .5 & .4 & 1.1 & 3.2 & 40.9 & 53.8 & 13.2 & 31.6 \\
\hline
\end{tabular}

TABLE V

PARTICLE SIZE DISTRIBUTION OF A CLAYEY-KAOLINITIC-MESICXERIC-HAPLOHUMULT, FROM NEVADA COUNTY, CA (U.S.D.A.-S.C.S, 1975)

\begin{tabular}{||l|l|l|l|l|l|l|l|l|}
\hline $\begin{array}{l}\text { Depth } \\
\text { (in.) }\end{array}$ & $\begin{array}{l}2-1 \\
\mathrm{~mm}\end{array}$ & $\begin{array}{l}1-.5 \\
\mathrm{~mm}\end{array}$ & $\begin{array}{l}.5- \\
.25 \\
\mathrm{~mm}\end{array}$ & $\begin{array}{l}.25- \\
.1\end{array}$ & $\begin{array}{l}.1- \\
\mathrm{mm}\end{array}$ & $\begin{array}{l}.05- \\
\mathrm{mm}\end{array}$ & $\begin{array}{l}.02- \\
\mathrm{mm}\end{array}$ & $\begin{array}{l}<.002 \\
\mathrm{~mm}\end{array}$ \\
\hline $0-18$ & 1.6 & 4.2 & 3.3 & 7.4 & 6.7 & 13.7 & 25.7 & 37.4 \\
\hline $18-36$ & .9 & 2.8 & 2.9 & 6.6 & 6.1 & 11.4 & 23.9 & 45.4 \\
\hline
\end{tabular}

From Tables IV and V, an average sediment distribution was calculated for the top 36 inches of soil at Hagg Lake. In order to define actual particle sizes from the given ranges, average particle sizes were chosen from the given size ranges. Six particle sizes were chosen to model the sedimentation processes in Hagg Lake. These particles would comprise the clay and silt components of soil, since larger particles would settle rather quickly. Table VI shows the clay particle sizes 
and percentages chosen for the Hagg Lake model. Table VII shows the silt particle sizes and percentages chosen for the Hagg Lake model.

TABLE VI

FRACTION OF CLAY PARTICLES FOR THE HAGG LAKE MODEL

\begin{tabular}{|l|l|l|l|}
\hline \hline Clay Particles & $\begin{array}{l}\text { Very Fine Clay } \\
\text { (SS1) }\end{array}$ & $\begin{array}{l}\text { Fine clay } \\
\text { (SS2) }\end{array}$ & $\begin{array}{l}\text { Coarse } \\
\text { Clay (SS3) }\end{array}$ \\
\hline Particle Size & $0.0002 \mathrm{~mm}$ & $0.0008 \mathrm{~mm}$ & $0.0014 \mathrm{~mm}$ \\
\hline Percentage & $16.60 \%$ & $16.60 \%$ & $16.60 \%$ \\
\hline \hline
\end{tabular}

TABLE VII

FRACTION OF SILT PARTICLES FOR THE HAGG LAKE MODEL

\begin{tabular}{|l|l|l|l|}
\hline \hline Silt Particles & $\begin{array}{l}\text { Very Fine Silt } \\
\text { (SS4) }\end{array}$ & $\begin{array}{l}\text { Fine silt } \\
\text { (SS5) }\end{array}$ & $\begin{array}{l}\text { Coarse } \\
\text { Silt (SS6) }\end{array}$ \\
\hline Particle Size & $0.002 \mathrm{~mm}$ & $0.010 \mathrm{~mm}$ & $0.030 \mathrm{~mm}$ \\
\hline Percentage & $14.90 \%$ & $14.90 \%$ & $14.24 \%$ \\
\hline
\end{tabular}

From Tables VI and VII, the fine soil particles account for $93.82 \%$ of the soil, and the coarse material is $6.18 \%$ of the soil. Thus, six particle size fractions were added to the Hagg Lake model (SS1, SS2, SS3, SS4, SS5, and SS6). These size fractions could be adjusted in the future for any soil type, for they were placed in the model as variables, dependent on their settling velocities which are chosen and placed in the revised CE-QUAL-W2 control file by the user (see Appendix A). As mentioned before, stoke's Law was used to 
derive settling velocities for the Hagg Lake Model.

Stoke's Law is given by (Thomann \& Mueller, 1987):

$$
V_{s}=\frac{g}{18.0}\left[\frac{\rho_{s}-\rho}{\mu}\right] d^{2}
$$

where:

$$
\begin{aligned}
& \mathrm{v}_{\mathbf{s}}=\text { settling velocity (m/day) } \\
& \mathrm{g}=\text { gravitational acceleration } \\
& \rho_{\mathrm{s}}=\text { particle density }\left(\mathrm{g} / \mathrm{cm}^{3}\right) \\
& \rho^{3}=\text { density of water }\left(\mathrm{g} / \mathrm{cm}^{3}\right) \\
& \mu \quad \text { dynamic viscosity of water } \\
& \mathrm{d} \quad=\text { particle diameter }(\mu \mathrm{m})
\end{aligned}
$$

While evaluating particle data for the sacramento-San Joaquin Delta in California, Di Toro and Nusser (1976) derived the following empirical relation for a particle's density:

$$
\rho_{s}=2.0 d^{-0.15}
$$

where:

$$
\begin{aligned}
& \rho_{\mathrm{s}}=\text { particle density }\left(\mathrm{g} / \mathrm{cm}^{3}\right) \\
& \mathrm{d}=\text { particle diameter }(\mu \mathrm{m})
\end{aligned}
$$

Using this empirical formula, particle densities were calculated for the six particle sizes listed before. By applying stoke's Law to the six particles, the following settling rates were obtained. These settling rates were required in the control file for the Hagg Lake CE-QUAL-W2 model. Table VIII shows the mean particle size, the calculated density, and stoke's settling velocity for each 
particle used in the Hagg Lake model. As one can see from Table VIII the particle densities calculated from Di Toro and Nusser's empirical formula appear to be very high for clay particles. A soil density of $2.5 \mathrm{~g} / \mathrm{cm}^{3}$ would be more reasonable. However, the densities calculatd and listed in Table VIII were used and this was a conservative approach.

\section{TABLE VIII}

SEDIMENT SETTLING RATES FOR HAGG LAKE

\begin{tabular}{||l|l|l|l|}
\hline Particle: & $\begin{array}{l}\text { Mean Particle } \\
\text { Size (mm) }\end{array}$ & $\begin{array}{l}\text { Calculated } \rho_{s} \\
\left(\mathrm{~g} / \mathrm{cm}^{3}\right)\end{array}$ & $\begin{array}{l}\text { Stoke's } \\
\text { Settling } \\
\text { Velocity } \\
(\mathrm{m} / \text { day })\end{array}$ \\
\hline SS1 & 0.0002 & 7.176 & 0.0021 \\
\hline SS2 & 0.0008 & 5.829 & 0.023 \\
\hline SS3 & 0.0014 & 5.359 & 0.059 \\
\hline SS4 & 0.002 & 5.08 & 0.1080 \\
\hline SS5 & 0.010 & 3.99 & 1.390 \\
\hline SS6 & 0.030 & 3.38 & 6.080 \\
\hline
\end{tabular}

OBSERVATIONS OF SEDIMENTATION AT HAGG LAKE

In 1989, the Oregon Department of Forestry began an analysis of water quality in the headwaters of the Tualatin River Basin (Fromuth, 1992). They performed analyses of several water quality parameters including suspended solids from the following sub-basins: Dairy Creek, Gales Creek, McKay Creek, and the Upper Tualatin. These analyses were 
performed during the summer months from 1989 through 1992 . Although the Hagg Lake sub-basin was not monitored, many of these monitoring stations were located in very similar subbasins as that of Hagg Lake. A review of the data performed by Agua Tierra Environmental (Fromuth, 1992) showed that some of the laboratory analysis were incorrect and some of the data were thrown out. Plots of the satisfactory data showed that a definite correlation existed between suspended solids and total phosphorus concentrations at many of the sites. The data also showed that flow rates were very minimal during the summer months. The report concluded that there was a need to monitor these streams during the winter months, especially during large rain events. The researchers hypothesized that the correlation between sediment and phosphorus transport may be dramatic during large winter storm events.

Researchers studying the Tualatin River Basin at Oregon State University (Miner and Scott, 1992) also reviewed the Department of Forestry's data. They found that suspended solids concentrations tended to be low, and that most of the flow during the summer period was reflective of groundwater both in quantity (between storm events) and quality. The following excerpt was taken from their review of four forested sub-basins (Gales Creek at Highway 6, Gales Creek at Forest Park, East Fork Dairy Creek at Fern Flat Road, and Upper McKay Creek) in the Tualatin Watershed (Miner and Scott, 1992, pg. 8). 
In total the forestry stations suggest that the streamflow during the summer months consists of groundwater inflow. There is no indication of surface runoff, nor is there any indication that forestry management practices are contributing to the level of nutrients in the streams.

one must remember that this study was performed during the summer season only and that the weather patterns during the summer in the Tualatin Basin are much different than the winter. As mentioned before, it has been found that a few (4 to 5) major winter storms contribute to the majority of suspended solids in this region. Therefore, the majority of sediments that eventually settle in Hagg Lake may be products of a few winter storms. In order to see how these storms could effect the turbidity of Hagg Lake in the summer, an exercise was performed using the Hagg Lake model to simulate these processes.

\section{A SIMULATION OF SEDIMENTS AT HAGG LAKE}

In order to track the fate of sediments in Hagg Lake, the following "exercise" was run using the Hagg Lake model. The model was run from January 1, 1990 through October 31, 1990 . Winter and spring storms were observed from analyzing inflow data to Hagg Lake (T.V.I.D., 1990). These storms were categorized by the amount of runoff flowing into the lake. Since no inflow suspended solids data existed, suspended solids concentrations were estimated from data taken by the Oregon state Department of Forestry at two adjacent sub-basins 
(Clear Creek and Lee Creek) in 1991 and 1992. These data did not show suspended solids concentrations during winter storms, therefore, these data were estimated. Table IX lists the suspended solids concentrations used for inflows to Hagg Lake.

\section{TABLE IX}

INORGANIC SUSPENDED SOLIDS CONCENTRATIONS USED FOR INFLOW TO HAGG LAKE 1990

\begin{tabular}{||l||c|l|l|l||}
\hline $\begin{array}{l}\text { Flow } \\
\text { Category }\end{array}$ & $\begin{array}{l}\text { Normal } \\
\text { Spring or } \\
\text { Winter }\end{array}$ & $\begin{array}{l}\text { Mild } \\
\text { Storm } \\
\text { Spring or } \\
\text { Winter }\end{array}$ & $\begin{array}{l}\text { Severe } \\
\text { Winter } \\
\text { Storm }\end{array}$ \\
\hline S.S. Conc. & $1-3 \mathrm{mg} / 1$ & $5 \mathrm{mg} / 1$ & $16 \mathrm{mg} / 1$ & $30 \mathrm{mg} / 1$ \\
\hline
\end{tabular}

These suspended solids concentrations were broken up into the six particle sizes listed earlier according to the fractions listed in Tables VI and VII. They were input to the model via inflow constituent concentration files for scoggins Creek, Sain Creek, and Tanner Creek. Since the suspended solids concentrations for inflow and initial conditions were estimated, the magnitudes of the results may at best be the same order-of-magnitude as those that actually occur.

Six graphs of the fate of particles in Hagg Lake were made (Figures 34 through 39). Figure 33 shows the location in the lake where model output of suspended particles was analyzed. 


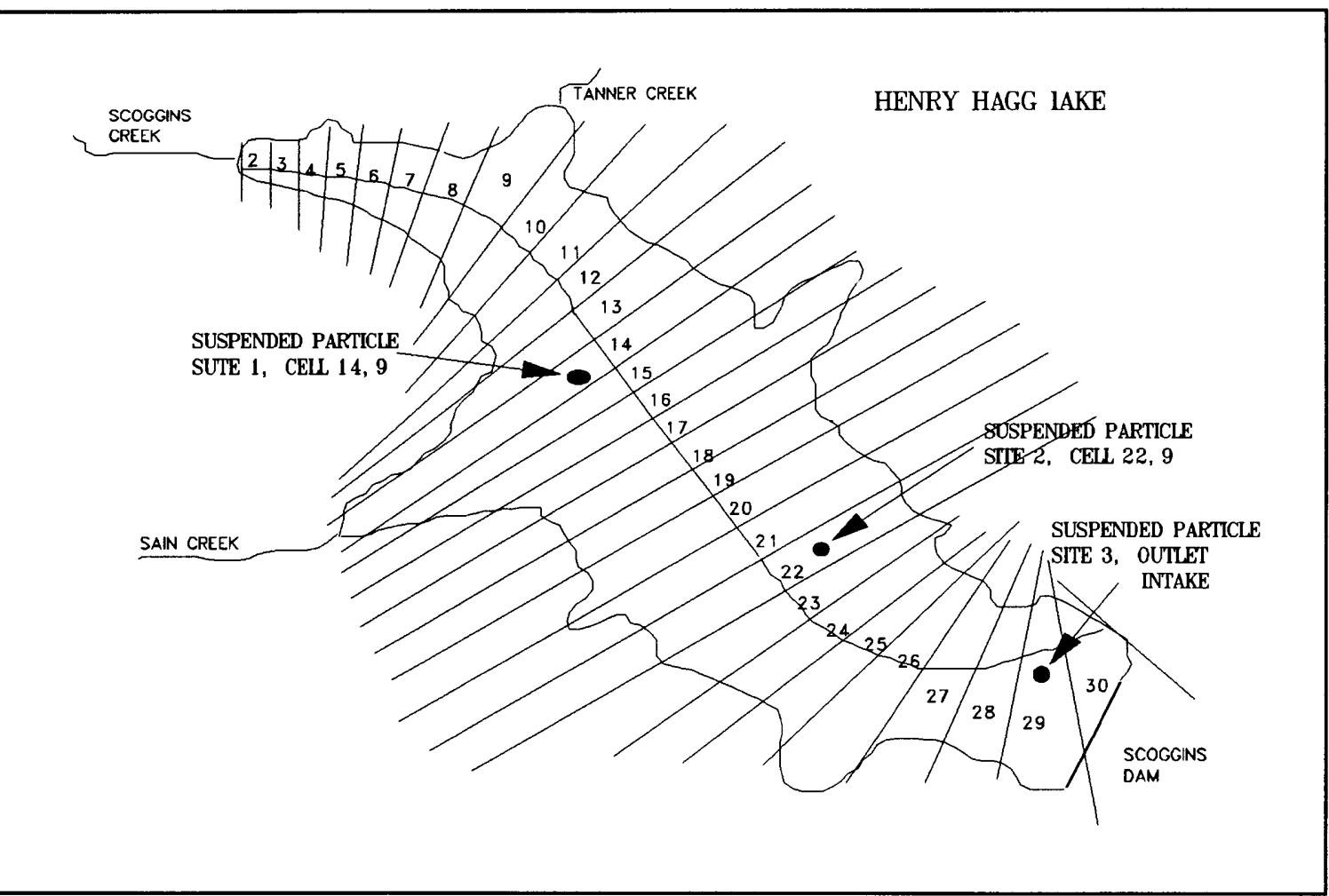

Figure 33. Hagg Lake site location for graphing suspended particle results.

Figure 34 shows the fate of each particle size class at site 1 (longitudinal cell 14, vertical cell 9) as a concentration versus Julian day. Figure 35 shows the sum of these particles (total inorganics) at the same location (site 1). Figure 36 shows the fate of each particle size class at site 2 (longitudinal cell 22, vertical cell 9) as a concentration versus Julian day. Figure 37 shows the sum of these particles at the same location (site 2). Figures 38 and 39 show the same the same respective processes as mentioned above for the outlet intake structure (site 3 ). 


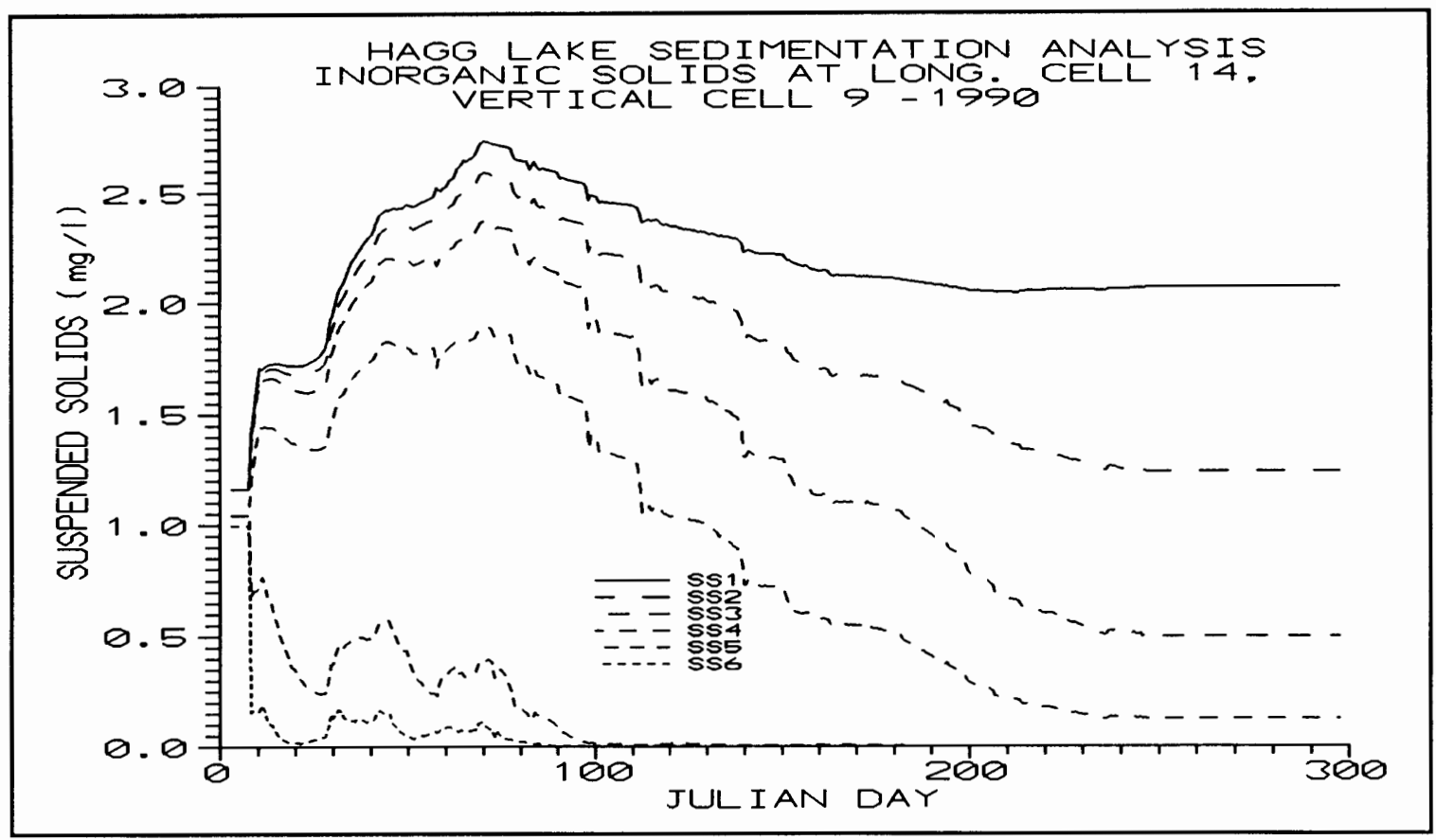

Figure 34. Concentrations of inorganic particles versus Julian day at longitudinal cell 14, vertical cell 9, 1990.

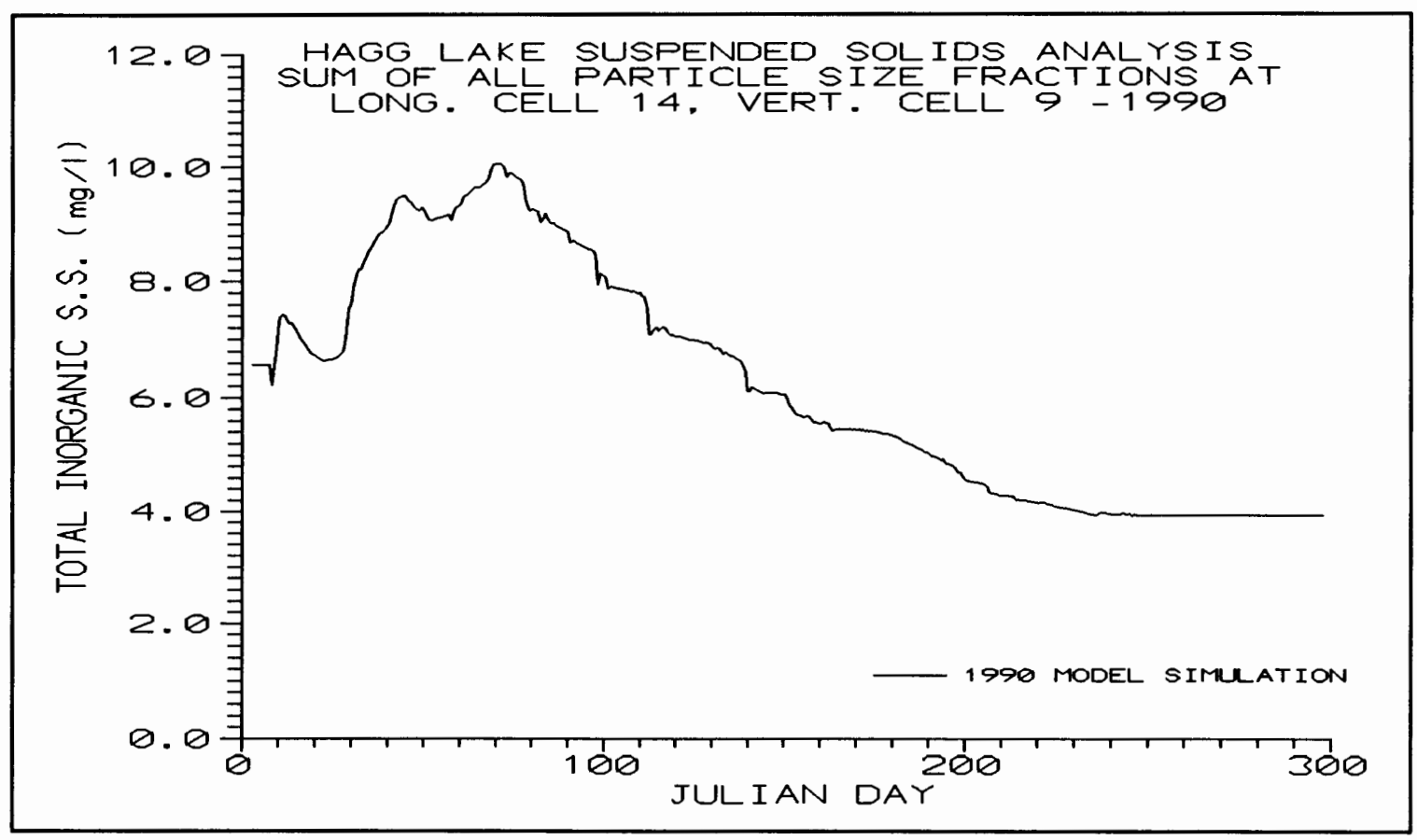

Figure 35. Sum of inorganics suspended solids versus Julian day at longitudinal cell 14, vertical cell 9, 1990 . 


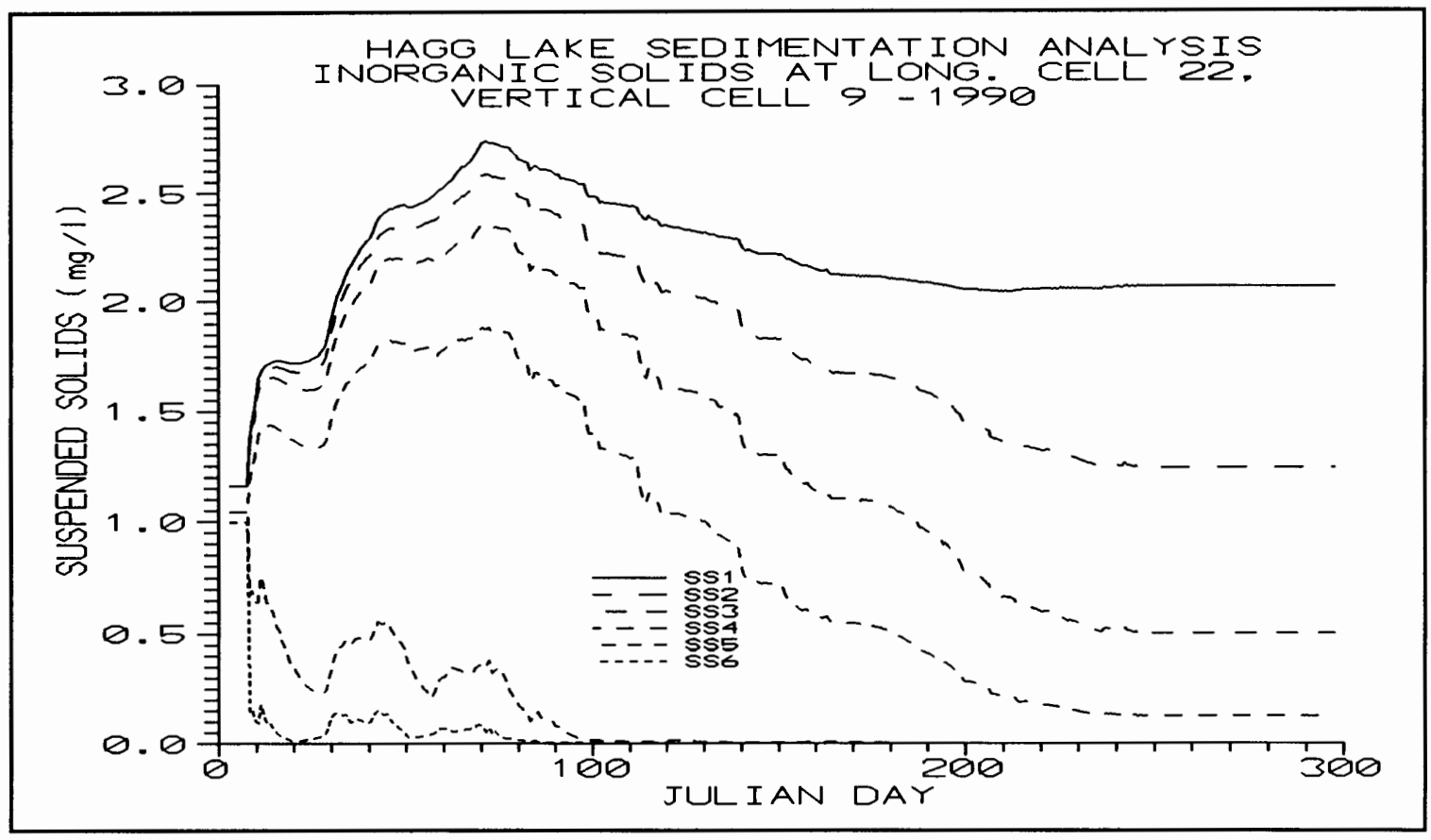

Figure 36. Concentrations of inorganic suspended solids versus Julian day at longitudinal cell 22, vertical cell 9, 1990.

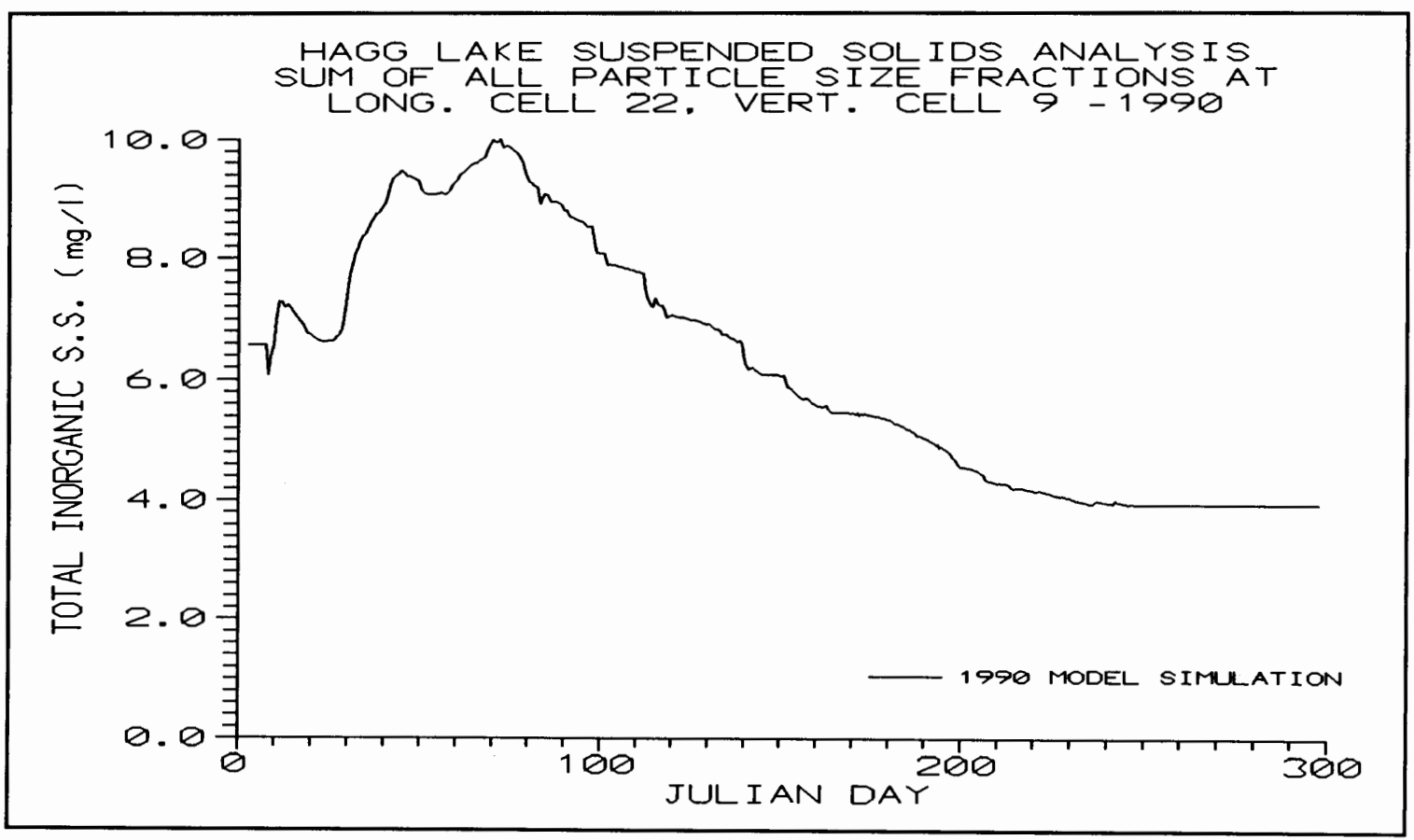

Figure 37. Sum of inorganic suspended solids versus Julian day at longitudinal cell 22 , vertical cell 9, 1990. 


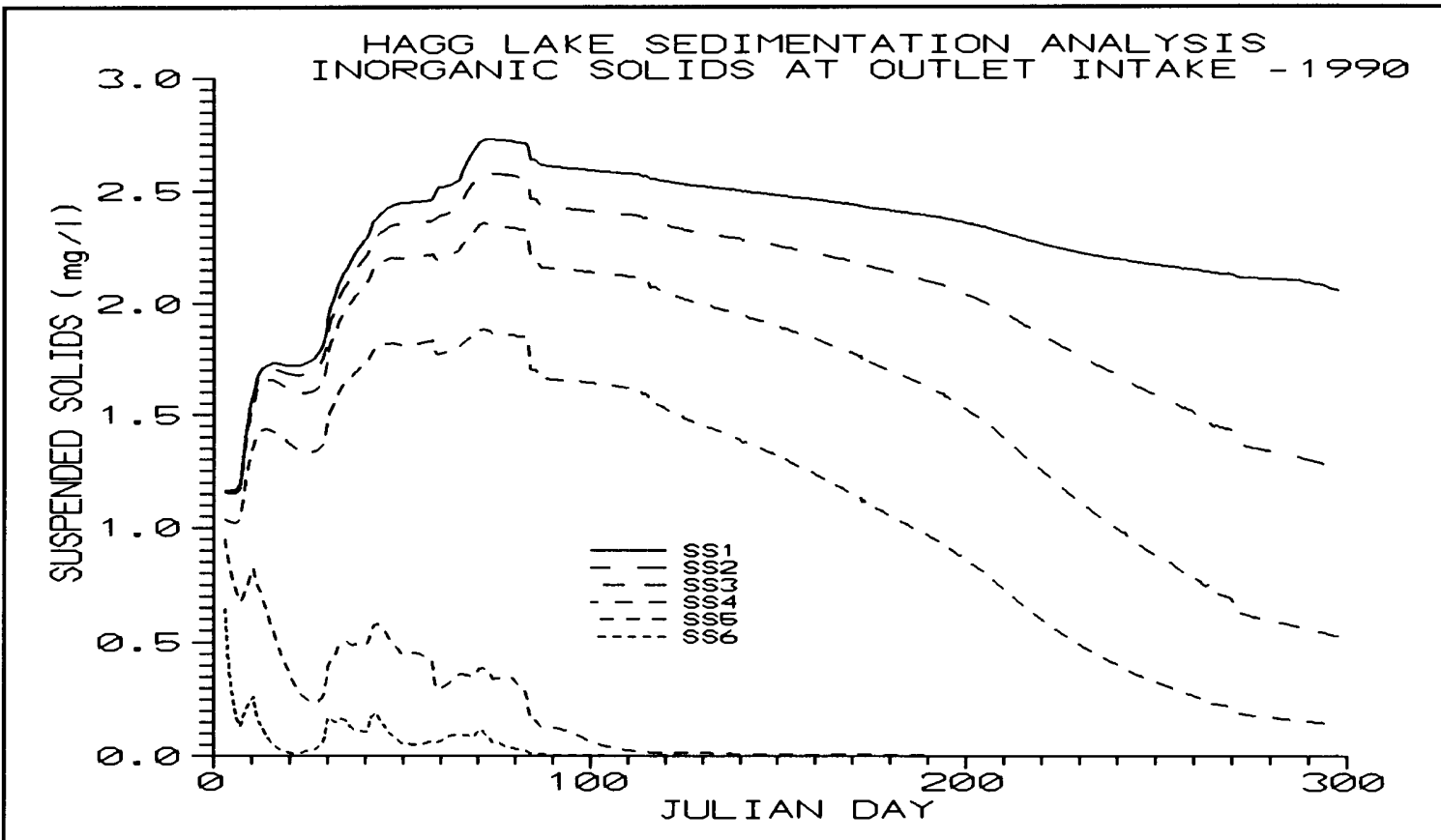

Figure 38. Concentrations of inorganic suspended solids versus Julian day at outlet intake structure, 1990.

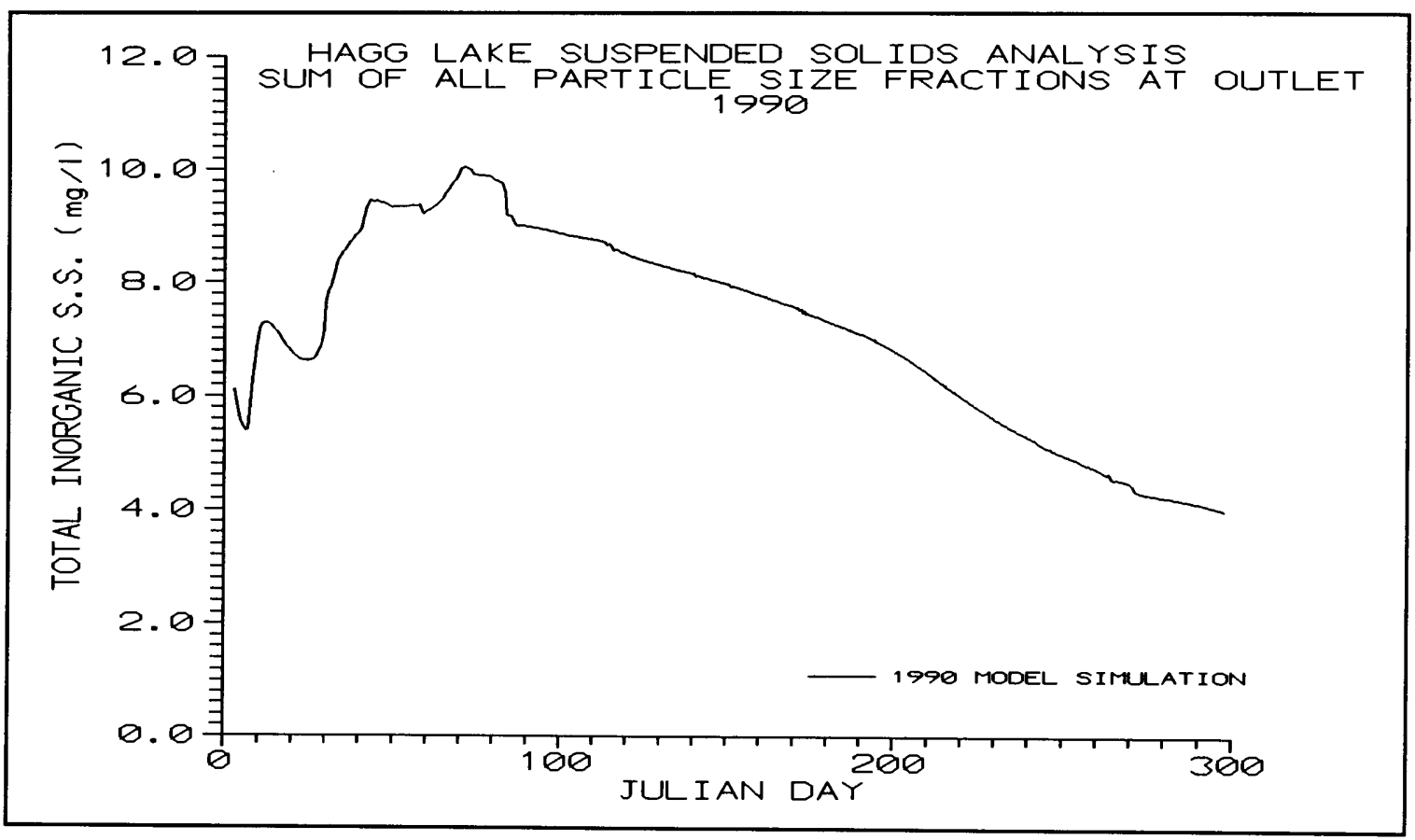

Figure 39. Sum of inorganic suspended solids versus Julian day at outlet intake structure, 1990. 
From Figures 34 through 37 , one can see that no change occurs between site 1 and site 2 , they both have nearly the same curves for all particle sizes. Both of these sites are located at the same depth (vertical cell 9), therefore, the plume of sediments must be well mixed throughout the lake for most of the period between sites 1 and 2 . Graphs for site 3 (Figures 38 and 39) show a slightly different sedimentation pattern than sites 1 and 2 . Curves for the four smallest particles are much more gradual than at sites 1 and 2 . Site 3 is located deeper (vertical cells 14, 15, and 16) than sites 1 and 2 and local hydraulics may draw particles toward the outlet. The lake appears to be well mixed in its upper layers because maximum concentrations are the same at all three sites, and at the end of the simulation (Julian day 300) concentrations of all particles approach the same concentrations. However, from Julian day 90 through Julian day 280 , the outlet has higher concentrations than the other two sites.

From Figures 34,36 , and 38 , one can see that particle sizes greater than SS4 $(0.002 \mathrm{~mm}$ ) settled out quickly (before May 1st). The smallest clay particles (SS1, SS2, and SS3) remained in the water column throughout the entire simulation. Figure 39 (outlet) shows that the total particle concentration on Julian day 120 (May 1st) was higher than U.S.A. TSS field data on Scoggins Creek for the same date. An initial profile concentration on Julian day 120 for ISS of 7 to $1 \mathrm{mg} / \mathrm{l}$ was 
used in calibrating the model and figure 39 shows a concentration of $8 \mathrm{mg} / \mathrm{l}$ at the outlet for this same date. Therefore, assumed storm loadings were high, however, sedimentation processes would be similar for lower concentrations of inorganics.

Further analysis of the sedimentation processes in Hagg Lake can be found in Appendix D. Appendix D contains Figures D.1 through D.5 which show sediment particle concentrations for the entire lake from this simulation using color plots produced from TECPLOT. 


\section{CHAPTER IX}

\section{SUMMARY AND CONCLUSIONS}

The modeling of Hagg Lake using the CE-QUAL-W2 model presented a "real" world difficulty. The difficulty with this model, as with many others, was that very little water quality data existed for this lake. In order to capture the complex water quality cycles of a water body such as Hagg Lake using CE-QUAL-W2, one would need a complete water quality data set spanning over at least one year. Included in this data set would be profile data for temperature, dissolved oxygen, and chlorophyl1-a concentrations. Also, water quality data for the tributaries that flow into the lake would be necessary, especially during the wet winter and spring months. For ideal modeling conditions, one would also like to have a local meteorological data set taken at the actual site during the study period. The meteorological data set used for the Hagg Lake model was from the Hillsboro Airport, approximately 15 miles to the east. The two sites are at similar altitudes. However, the influence of the coast Range on Hagg Lake could provide drastic differences in wind patterns between the two sites.

With the limited data set available, the Hagg Lake model produced results of varying accuracy. The modeled nitrate 
and temperature output curves fit the outflow data reasonably. Modeled temperature profiles for the lake appeared to resemble a profile for Hagg Lake that one might expect with a welldefined epilimnion, thermocline, and hypolimnion. However, without actual profile data for the lake, it would be impossible to say if this modeled profile was accurate. other modeled water quality parameters with outflow data (i.e. Po $_{4}$, $\mathrm{NH}_{3}$, TSS, TDS, and $\mathrm{Ph}$ ) were "within the ballpark", but did not show the dynamics that existed for the data.

The hardest part of the calibration process was in trying to get $\mathrm{PO}_{4}$ and $\mathrm{NO}_{3}$ to be stripped out of the water column near the middle of the summer season (approximately August 15th). In the end, the only mechanism in the model which had much effect on $\mathrm{PO}_{4}$ and $\mathrm{NO}_{3}$ concentrations was algal growth. Therefore, to strip out these nutrients, an algal bloom had to begin at the middle of the summer season that would produce high algal populations near the outlet intake structure. However, the outlet intake structure was located at significant depth even at the end of the withdrawal season. By adjusting the coefficient for algal sensitivity to light intensity (ASATUR), larger algal populations occurred at depth and $\mathrm{PO}_{4}$ and $\mathrm{NO}_{3}$ were stripped out. This resulted in an algal population that was very light sensitive. This algal population survived at differing water levels during the summer season depending on the light intensity. The nutrients were stripped out as the data showed, but this occurred at the 
cost of having an algal population which may not have been representative of the actual populations in Hagg Lake.

A sensitivity analysis was not performed for coefficients used in the Hagg Lake model. There are nearly 100 coefficients used in the CE-QUAL-W2 model and time did not allow for a sensitivity analysis. The Hagg Lake model was observed to be most sensitive to initial summer season conditions. As explained earlier, due to low summer inflows, initial water quality conditions in Hagg Lake direct the fate of water quality in the lake for the summer season. The fractions of water taken at the outflow intake structure from vertical cells 14, 15, and 16 (FRACT1, FRACT2, and FRACT3) were also very sensitive during calibration. Slight changes in the percentages of water taken from these cells changed the location where the epilimnion, thermocline, and the hypolimnion occurred. Thus, the temperature and water quality regime was shifted, resulting in different modeled output for the outflow to Scoggins creek.

From observations of the lake itself and the available data, no water quality problems appear to exist at Hagg Lake. When compared to water in the lower reaches of the Tualatin River, it could be said that Hagg lake has excellent water quality. The Hagg Lake model provides water quality and hydraulic simulations that are "within the ballpark" as an average. Temperature, nitrate, and hydraulic predictions appear to be very realistic. The model has not been 
calibrated for winter (November through April) conditions. Thus, it would be unwise to speculate on its accuracy for this period without field data.

The Hagg Lake model was used to determine the effects on water quality if additional outflow were allowed during the withdrawal season. An additional $100 \mathrm{cfs}$ was added to the outflow from Hagg Lake from June 15, 1990 through september 15, 1990. The results of this analysis showed that water quality would not be drastically effected. Outflow water quality would not be as good as previous, but it may be adequate for the Tualatin River. Recreation at Hagg Lake would be most severely impacted. Depending on downstream demands, the pool in the lake may drop to levels where most recreation at the lake would not be possible. Since high recreational demands occur during high withdrawal seasons (dry and warm), the two could not coexist with this additional outflow. Additional outflow from Hagg Lake could be provided by increasing the storage capacity of the lake through dredging or raising the dam. However, this alternative could be very expensive.

Five additional inorganic particle sizes were added to the Hagg Lake model. This allowed one to track the fate of six different inorganic particle sizes with different settling rates in Hagg Lake. An exercise was performed with the model to show the destiny of six particles associated with soils which are predominant on the shores of Hagg Lake. The bulk of 
this suspended sediment was introduced into the lake through its tributaries from five to six winter and spring storm events. The exercise reinforced the hypothesis that very fine sediments may remain suspended in the lake throughout the summer season as a result of runoff from a few winter and spring storm events.

Due to time constraints, other sources of turbidity were not examined. Observations at Hagg Lake confirmed the fact that shoreline erosion is taking place at Hagg Lake from both waves crashing on the shore and lowering the pool. It appears that these processes are occurring at fairly high levels. The soils around Hagg Lake tend to be fine to very fine silty clay loams which may remain suspended in the water column for long periods of time. Further turbidity problems could result from increased logging in the watershed around Hagg Lake should it occur in the future. The watershed is largely privately owned and the second growth douglas fir which covers most of the watershed has matured to harvestable timber. 


\section{REFERENCES}

Beeton, A.M., "Relationship between Secchi Disk Readings and Light Penetration in Lake Huron, Transaction, American Fisheries Society, vol. 87, 1958, pp. 73-79.

Brune, G.M., "Trap Efficiency of Reservoirs," Transactions, American Geophysical Union, Vol. 34, No. 3, 1953, pp. 407418 .

DiToro, D.M. and Nusser, J., "Particle Size and Settling Velocity Analyses for Bay Area Waters," Hydroscience, Inc., report prepared for California Department of Water Resources, 1976.

Edinger, J.E., and Buchak, E.M., "Numerical Hydrodynamics of Estuaries," Estuarine and Wetland Processes with Special Emphasis on Modeling, ed. by P. Hamilton and K.B. MacDonald, Plenum Press, NY, 1978, pp. 115-146.

Federal Water Pollution Control Administration, "Summary Willamette River Basin Water Quality Control and Management," U.S. Department of the Interior, Northwest Region, Portland, Oregon, 1967.

Fromuth, C., "Phosphorous Monitoring in the Tualatin River Basin - A Review of the Oregon Department of Forestry Program for a TMDL Basin 1989-1991," Agua Tierra Environmental Consulting, a report prepared for the oregon Department of Forestry, 1992 .

Green, G.L., "Soil Survey of Washington County, Oregon," U.S.D.A. Soil Conservation Service, in cooperation with Oregon Agricultural Experimentation Station, 1982.

James, A., "Introduction to Mathematical Modelling," $\underline{\text { An }}$ Introduction to Water Quality Modelling, ed. by A. James, John Wiley \& Sons Ltd., 1984, pp. 1-17.

Johnson, D.M., Schaedel, A.L., et. al., Atlas of Oregon Lakes, oregon State Univerisity Press, Corvallis, Oregon, 1985.

Klingeman, P.C., et. al., "Hills Creek Reservoir Turbidity Study," Water Resources Research Institute, No. 14 , Oregon State University, Corvallis, Oregon, December, 1971. 
Leonard, B.P., "A Stable and Accurate Convection Modelling Procedure Based on Quadratic Upstream Interpolation," Computer Methods in Applied Mechanical Engineering, No. 19, 1979, pp. 59-98.

Linsley, R.K., Franzini, J.B., water Resources Engineering, 3rd ed., McGraw-Hill Book Company, 1979.

Lopez, S., "Mathematical Modeling of Sediment Deposition in Reservoirs," Colorado State University Press, Fort Collins, Colorado, No. 95, July, 1978.

Madsen, O.S., "Sediment Transport and Coastal Processes," lecture notes on Mechanics of sediment Transport in steady Flow, M.I.T., Department of Civil Engineering, 1975.

Miner, J.R., Scott, E., "An Analysis of Water Quality Data in Tualatin River Tributaries with Three Different Land Uses," Tualatin River Basin Water Resources Management Report, No. 3., Oregon Water Resources Research Institute, July, 1992.

Oregon Department of Environmental Quality, "Citizen Lake watch," unpublished data, Portland, Oregon, 1990.

Orlob, G.T., "One-dimensional Models for simulation of Water Quality in Lakes and Reservoirs," Mathematical Modeling of Water Quality: Streams, Lakes, and Reservoirs, ed. by G.T. Orlob, John Wiley \& Sons, 1983, pp. 227-268.

Orlob, G.T., "Models for stratified Impoundments," Models for Water Quality Management, ed. by A.K. Biswas, McGraw-Hill Inc. 1981, pp. 272-312.

Otte, G.E., et. al., "Soil Survey of Yamhill Area, oregon," U.S.D.A. Soil Conservation Service, coop with Oregon Agricultural Experimentation Station, 1974.

otto, W., personal communication, Tualatin Valley Irrigation District, Hillsboro, Oregon, 1991.

Port of Portland, Portland-Hillsboro Airport, unpublished data, Hillsboro, Oregon, 1990, 1991.

streeter, H.W., Phelps, E.B., "A study of Pollution and Natural Purification of the Ohio River," U.S. Public Health Service, Publication Health Bulletin, no. 146, February, 1925.

Sverdup, H.U., Johnson, M.W., Fleming, R.H., The Oceans, Prentice-Hall, Englewood Cliffs, NJ, 1942. 
Symons, J.M., Water Quality Behavior in Lakes and Reservoirs, U.S. Dept. of Health, Education and Welfare, 1969 .

Taylor, G., unpublished data, oregon state climatologist, oregon state University, Corvallis, oregon, 1990, 1991.

Tchobanoglous, G, Schroeder, E.D., water Quality, AddisonWesley Publishing Inc., 1985.

Thomann, R.V., Mueller, J.A., principles of Surface Water Quality Modeling and Control, Harper and Row Publishers Inc., NY, NY, 1987 .

Tualatin Valley Irrigation District, unpublished data, Hillsboro, Oregon, 1990, 1991.

Unified Sewerage Agency, unpublished data, Hillsboro, Oregon, $1990,1991$.

U.S.A.C.E., "CE-QUAL-W2: A Numerical Two-Dimensional, Laterally Averaged Model of Hydrodynamics and Water Quality: Users Manual," Environmental and Hydraulics Laboratory, Waterways Experiments Station, Vicksburg, Mississippi, $1986 a$.

U.S.A.C.E., "CE-QUAL-R1: A Numerical one-Dimensional Model of Reservoir Water Quality: User's Manual," Environmental and Hydraulics Laboratory, Waterways Experiments station, Vicksburg, Mississippi, 1986 b.

U.S.A.C.E., "DRAFT- Updated CE-QUAL-W2 User's Manual," Waterways Experiments Station, Vicksburg, Mississippi, 1990.

U.S.A.C.E., "HEC-6 - Scour and Deposition in Rivers and Reservoirs: User's Manual," U.S. Dept. of Commerce, Springfield, Virginia, June, 1991.

U.S.A.C.E., "DRAFT- Updated CE-QUAL-W2 User's Manual," Waterways Experiments Station, Vicksburg, Mississippi, 1992 .

U.S.D.A., Soil Conservation Service, "Erosion, Sediment and Related Salt Problems and Treatment oppurtunities," December, 1974.

U.S.D.A., Soil Conservation Service, Soil Taxonomy - A Basic System of Soil Classification for Making and Interpreting Soil Surveys, Agricultural Handbook no. 436, December, 1975.

U.S. Dept. of the Interior, Bureau of Reclamation, unpublished data, Boise, Idaho, 1970.

U.S.G.S., Quadrangle Topographic Maps, Portland, Oregon. 
Walesh, S.G., Urban Surface Water Management, John Wiley and Sons, 1989, pp. 337-354.

Washington county, soil and water Conservation District, "Upper Tualatin River Streambank Erosion Control Project: Summary Report," June, 1983.

Washington County, "Henry Hagg Lake, Scoggins Valley Park," Brochure, Washington County Dept. of support Services, Facilities Management Division, Hillsboro, Oregon.

Wetzel, R.G., Limnology, W.B. Saunders Company, 1975.

Wolf, D.W., "A Literature Review: Land Use and Nonpoint Phosphorus Pollution in the Tualatin Basin, Oregon," Special Report no. 898, Oregon State University Extension Service and Water Resources Research Institute, Corvallis, Oregon, 1992 . 


\section{APPENDIX A}

WATER QUALITY CYCLES IN CE-QUAL-W2

(Corps of Engineers, 1986a, 1990) 
The source/sink term for each water quality constituent $\left(S_{k}\right.$ in equation 6$)$ in the $C E-Q U A L-W 2$ model are quantified in Table A-1. The water quality cycles that these equations correspond to are shown graphically in Figures A.1 through A.14 for algae, coliform, detritus, oxygen, inorganic carbon, suspended solids, labile dissolved organic matter, ammonia, nitrite+nitrate, ortho-phosphorus, refractory organic matter, sediment, iron, and zooplankton.

TABLE A-1

SOURCE SINK TERM EQUATIONS USED IN THE MODIFIED VERSION OF CE-QUAL-W2

\begin{tabular}{|c|c|c|c|}
\hline & Parameter & $\begin{array}{c}\text { Variable } \\
\text { Conc. } \\
\left(\mathrm{g} / \mathrm{m}^{3}\right)\end{array}$ & Source/Sink Term \\
\hline 1 & $\begin{array}{l}\text { Conservative } \\
\text { Tracer }\end{array}$ & $C_{1}$ & $S_{1}=0$ \\
\hline 2 & SS1 & $C_{2}$ & $S_{2}=\frac{\omega_{1} V C_{2}}{\Delta Z}$ \\
\hline 3 & $\begin{array}{l}\text { Coliform } \\
\text { Bacteria }\end{array}$ & $C_{3}$ & $S_{3}=-K_{\underline{c}} \theta^{(\underline{T}-20)} V C_{3}$ \\
\hline 4 & $\begin{array}{l}\text { Total Dissolved } \\
\text { Solids }\end{array}$ & $C_{4}$ & $S_{4}=0$ (conservative $)$ \\
\hline
\end{tabular}




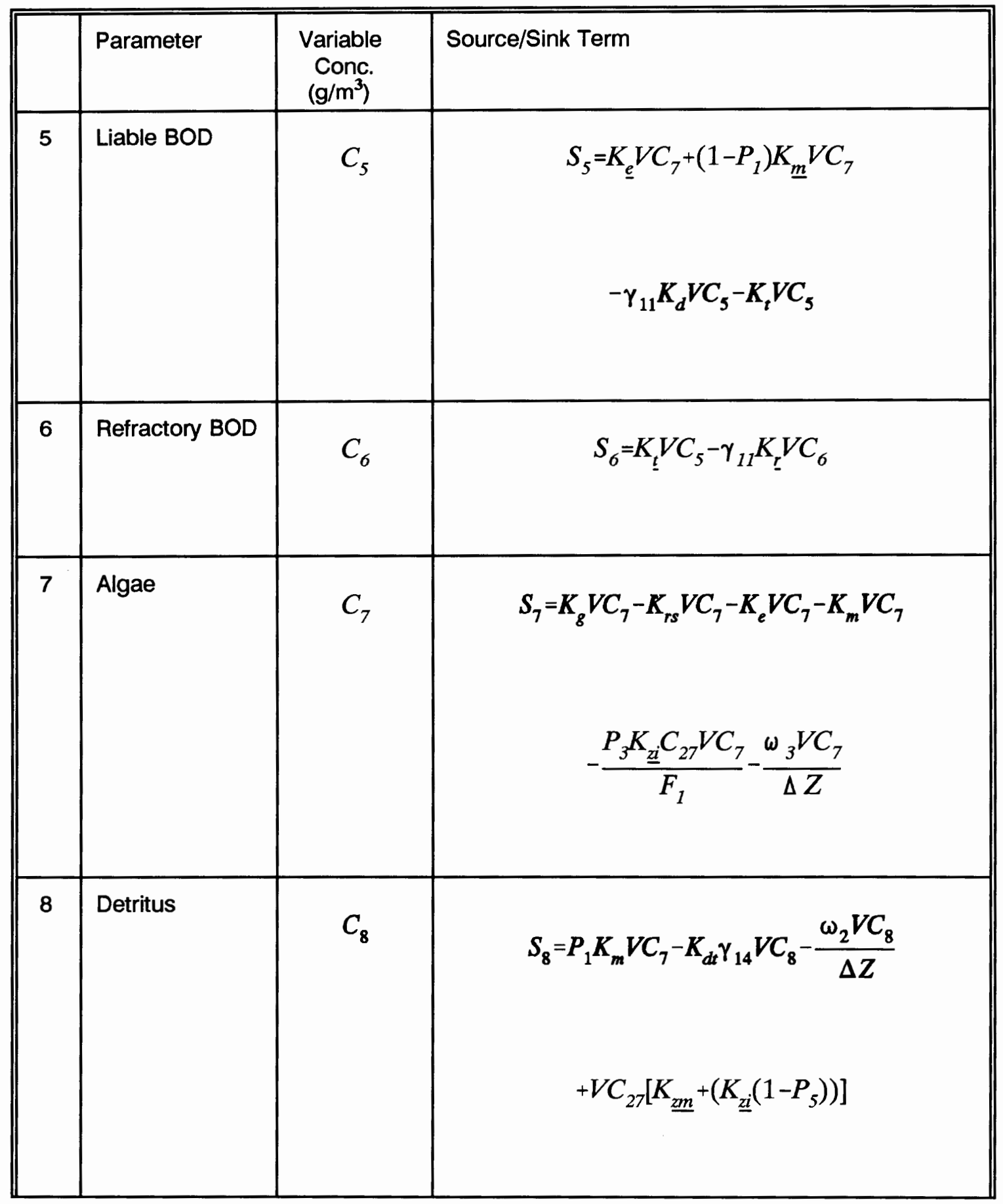




\begin{tabular}{|c|c|c|c|}
\hline & Parameter & $\begin{array}{c}\text { Variable } \\
\text { Conc. } \\
\left(\mathrm{g} / \mathrm{m}^{3}\right)\end{array}$ & Source/Sink Term \\
\hline 9 & Phosphorus & $C_{9}$ & 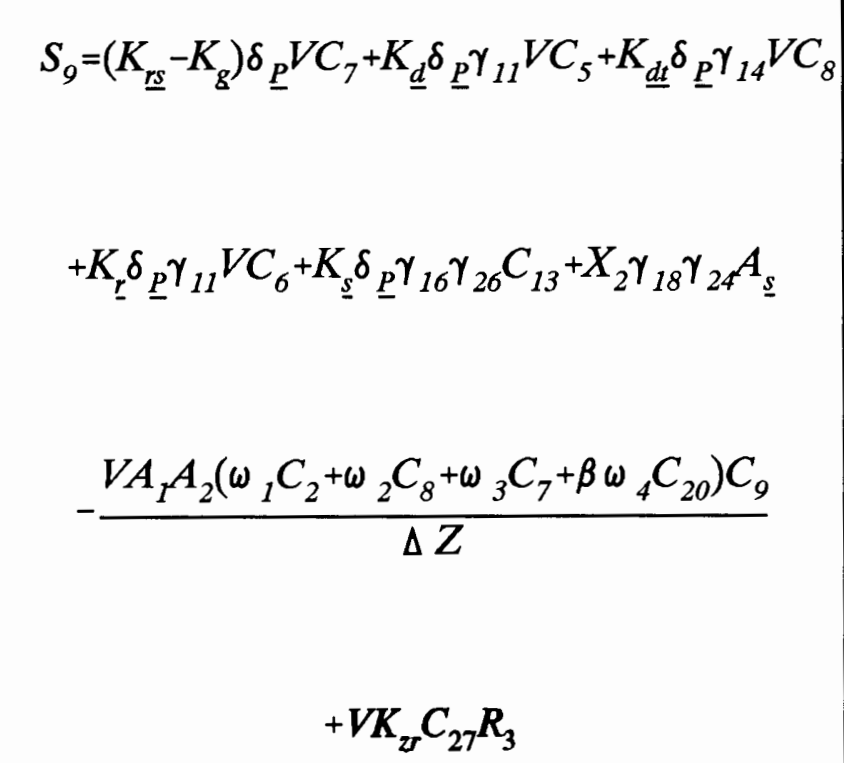 \\
\hline 10 & $\begin{array}{l}\text { Ammonia- } \\
\text { Nitrogen }\end{array}$ & $C_{10}$ & 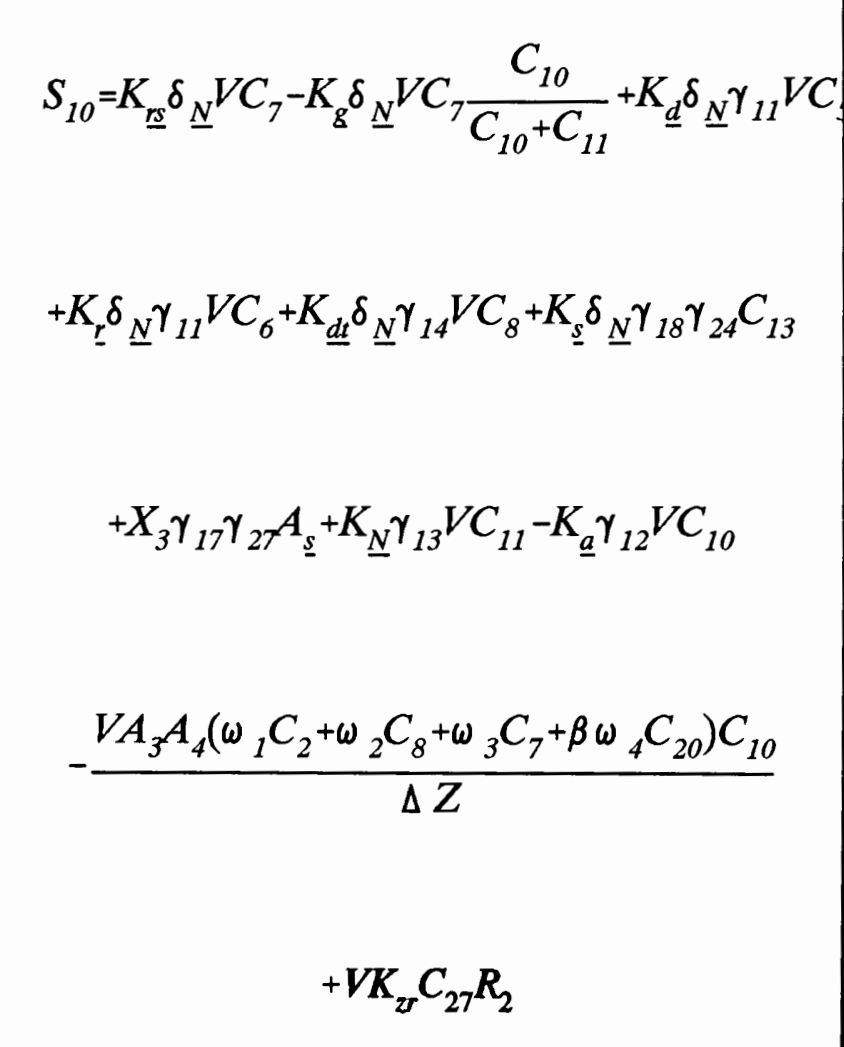 \\
\hline
\end{tabular}




\begin{tabular}{|c|c|c|c|}
\hline & Parameter & $\begin{array}{c}\text { Variable } \\
\text { Conc. } \\
\left(\mathrm{g} / \mathrm{m}^{3}\right)\end{array}$ & Source/Sink Term \\
\hline 11 & $\begin{array}{l}\text { Nitrate - } \\
\text { Nitrogen }\end{array}$ & $C_{11}$ & $\begin{array}{r}S_{11}=K_{\underline{a}} \gamma_{12} V C_{10}-K_{\underline{n}} \gamma_{13} V C_{11} \\
-K_{g} \delta_{N} V C_{7}\left(1-\frac{C_{10}}{C_{10}+C_{11}}\right)\end{array}$ \\
\hline 12 & $\begin{array}{l}\text { Dissolved } \\
\text { Oxygen }\end{array}$ & $C_{12}$ & 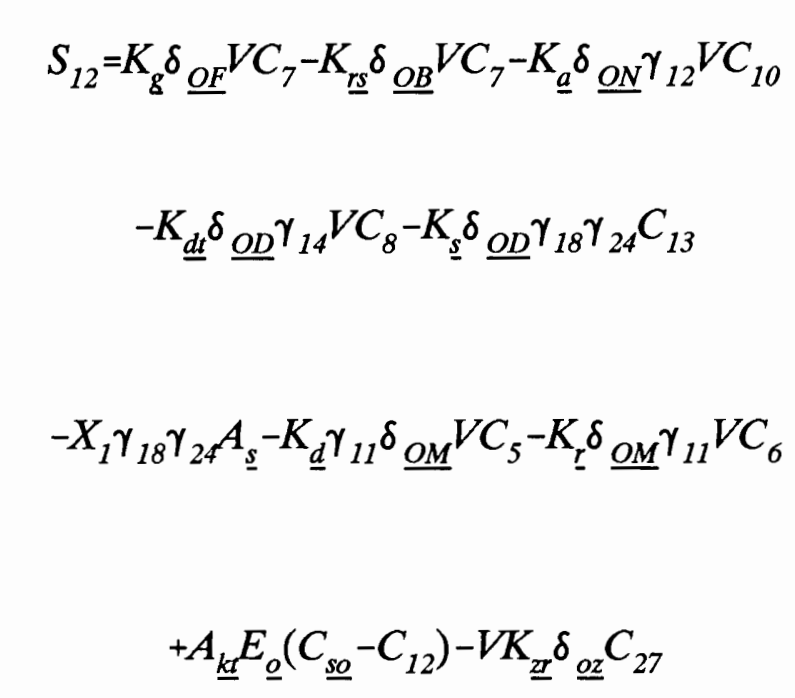 \\
\hline 13 & Sediment & $C_{13}$ & $\begin{array}{l}\qquad \frac{d C_{13}}{d t}=\frac{\omega_{2} V C_{8}}{\Delta Z}+\frac{\omega_{3} V C_{7}}{\Delta Z}-\gamma_{18} \gamma_{28} K_{s} C_{13} \\
\text { where } C 13 \text { is in units of sediment mass, gm; first- } \\
\text { order decay of organic solids: algae and detritus }\end{array}$ \\
\hline
\end{tabular}




\begin{tabular}{|c|c|c|c|}
\hline & Parameter & $\begin{array}{c}\text { Variable } \\
\text { Conc. } \\
\left(\mathrm{g} / \mathrm{m}^{3}\right)\end{array}$ & Source/Sink Term \\
\hline 14 & $\begin{array}{l}\text { Inorganic } \\
\text { Carbon }\end{array}$ & $C_{14}$ & 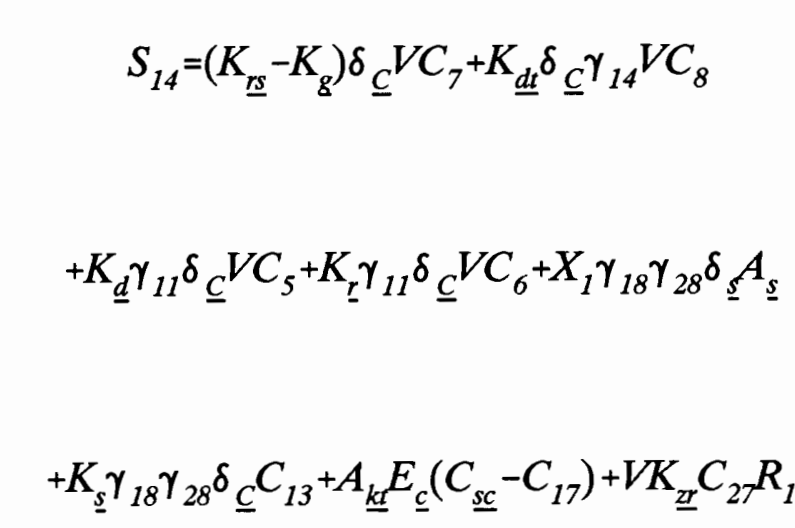 \\
\hline 15 & Alkalinity & $C_{15}$ & $S_{15}=0$ (conservative) \\
\hline 16 & $\mathrm{pH}$ & $C_{16}$ & $\begin{array}{l}\text { Equations for solution based on the carbonate } \\
\text { bicarbonate equilibrium reactions: } \\
\qquad \mathrm{CO}_{2}+\mathrm{H}_{2} \mathrm{O}=\mathrm{H}_{2} \mathrm{CO}_{3}=\mathrm{H}^{+}+\mathrm{HCO}_{3}^{-} \\
\qquad \mathrm{HCO}_{3}^{-} \approx \mathrm{CO}_{3}^{-2}+\mathrm{H}^{+} \\
\mathrm{H}_{2} \mathrm{O} \sharp \mathrm{H}^{+}+\mathrm{OH}^{-}\end{array}$ \\
\hline 17 & Carbon Dioxide & $C_{17}$ & -Same as $\mathrm{pH}$ \\
\hline
\end{tabular}




\begin{tabular}{|c|c|c|c|}
\hline & Parameter & $\begin{array}{c}\text { Variable } \\
\text { Conc. } \\
\left(\mathrm{g} / \mathrm{m}^{3}\right) \\
\end{array}$ & Source/Sink Term \\
\hline 18 & Bicarbonate & $C_{18}$ & -Same as pH \\
\hline 19 & Carbonate & $C_{19}$ & -Same as $\mathrm{pH}$ \\
\hline 20 & Iron & $C_{20}$ & $S_{20}=X_{4} \gamma_{18} \gamma_{28} A \underline{s}-\frac{V \omega{ }_{4} C_{20}}{\Delta Z}$ \\
\hline 21 & BOD-5 & $C_{21}$ & $S_{21}=-K_{\underline{b}} \theta^{\underline{T}-20} C_{21}$ \\
\hline 22 & ss2 & $C_{22}$ & $S_{22}=\frac{\omega_{5} V C_{22}}{\Delta Z}$ \\
\hline 23 & SS3 & $C_{23}$ & $S_{23}=\frac{\omega_{6} V C_{23}}{\Delta Z}$ \\
\hline 24 & SS4 & $C_{24}$ & $S_{24}=\frac{\omega_{7} V C_{24}}{\Delta Z}$ \\
\hline
\end{tabular}




\begin{tabular}{||l|l|c|c||}
\hline \hline 25 & Parameter & $\begin{array}{c}\text { Variable } \\
\text { Conc. } \\
\left(\mathrm{g} / \mathrm{m}^{3}\right)\end{array}$ & Source/Sink Term \\
\hline 26 & SS6 & $C_{25}$ & $S_{25}=\frac{\omega_{8} V C_{25}}{\Delta Z}$ \\
\hline 27 & Zooplankton & $C_{27}$ & $S_{27}=\gamma_{1} \gamma_{2} Z_{\underline{\underline{e}}} K_{\max }\left[\left(F_{1}-Z_{\underline{\underline{L}}}\right) /\left(F_{1}+Z_{1 / 2}\right)\right] V C_{27}$ \\
\hline
\end{tabular}

Table A-2 provides variable definitions for the variables in Table $\mathrm{A}-1$. It also lists variable names that are in the modified CE-QUAL-W2 control file. Variables where "not used" is listed under "Control File" are either computed by the program, or not input by the user, but are variables "hard wired" into the actual program. 
TABLE A-2

VARIABLE DEFINITIONS FOR WATER QUALITY CYCLE EQUATIONS USED IN CE-QUAL-W2

\begin{tabular}{|c|c|c|c|c|c|}
\hline $\begin{array}{l}\text { Control } \\
\text { File }\end{array}$ & $\begin{array}{l}\text { Eq. } \\
\text { Var. }\end{array}$ & Definition & $\begin{array}{l}\text { Control } \\
\text { File }\end{array}$ & $\begin{array}{l}\text { Eq. } \\
\text { Var. }\end{array}$ & Definition \\
\hline AHSP & $A_{1}$ & $\begin{array}{l}\mathrm{PO}_{4} \text { adsorption } \\
\text { coefficient, } \mathrm{m}^{3} / \mathrm{g}\end{array}$ & ALGDET & $P_{1}$ & $\begin{array}{l}\text { partition coefficient for } \\
\text { algal mortality }\end{array}$ \\
\hline PARTP & $A_{2}$ & $\begin{array}{l}\text { max. mass of } \\
\mathrm{PO}_{4} \text { adsorbed } \\
\text { per mass of } \\
\text { solids }\end{array}$ & $\begin{array}{l}\text { PREF1 } \\
\text { PREF2 }\end{array}$ & $P_{3}$ & $\begin{array}{l}\text { preference factor of } \\
\text { zooplankton for algae }\end{array}$ \\
\hline AHSN & $A_{3}$ & $\begin{array}{l}\text { ammonia } \\
\text { adsorption } \\
\text { coefficient, } \mathrm{m}^{3} / \mathrm{g}\end{array}$ & $\mathrm{BIOC}$ & $R_{1}$ & $\begin{array}{l}\text { ratio between carbon } \\
\text { and organic matter }\end{array}$ \\
\hline PARTN & $A_{4}$ & $\begin{array}{l}\text { max. mass of } \\
\text { ammonia } \\
\text { adsorbed per } \\
\text { mass solids }\end{array}$ & BION & $\mathrm{R}_{2}$ & $\begin{array}{l}\text { ratio between nitrogen } \\
\text { and organic matter }\end{array}$ \\
\hline not used & $A_{k t}$ & $\begin{array}{l}\text { surface area of } \\
\text { upper model } \\
\text { cell, } \mathrm{m}^{2}\end{array}$ & BIOP & $\mathrm{R}_{3}$ & $\begin{array}{l}\text { ratio between } \\
\text { phosphorus and organic } \\
\text { matter }\end{array}$ \\
\hline not used & $A_{s}$ & $\begin{array}{l}\text { sediment area, } \\
\mathrm{m}^{2}\end{array}$ & TEMP & $T$ & $\begin{array}{l}\text { temperature of water, } \\
{ }^{\circ} \mathrm{C}\end{array}$ \\
\hline not used & $C_{s c}$ & $\begin{array}{l}\text { carbon dioxide } \\
\text { saturation } \\
\text { concentration, } \\
\mathrm{g} / \mathrm{m}^{3}\end{array}$ & not used & V & cell volume, $\mathrm{m}^{3}$ \\
\hline not used & $C_{\text {so }}$ & $\begin{array}{l}\text { saturation } \\
\text { dissolved } \\
\text { oxygen } \\
\text { concentration, } \\
\mathrm{g} / \mathrm{m3}\end{array}$ & SOD & $x_{1}$ & $\begin{array}{l}\text { rate of sediment oxygen } \\
\text { demand, } g / m_{2} \text { sec }\end{array}$ \\
\hline not used & $E_{c}$ & $\begin{array}{l}\text { inorganic carbon } \\
\text { interfacial } \\
\text { exchange rate, } \\
\mathrm{m} / \mathrm{sec}\end{array}$ & PO4REL & $x_{2}$ & $\begin{array}{l}\text { anaerobic sediment } \\
\text { release rate, } \mathrm{g} / \mathrm{m}^{2} \mathrm{sec}\end{array}$ \\
\hline not used & $E_{0}$ & $\begin{array}{l}\text { oxygen } \\
\text { interfacial } \\
\text { exchange rate, } \\
\mathrm{m} / \mathrm{sec}\end{array}$ & NH3REL & $x_{3}$ & $\begin{array}{l}\text { sediment ammonia } \\
\text { release rate, } \mathrm{g} / \mathrm{m}^{2} \text { sec }\end{array}$ \\
\hline
\end{tabular}




\begin{tabular}{|c|c|c|c|c|c|}
\hline $\begin{array}{l}\text { Control } \\
\text { File }\end{array}$ & $\begin{array}{l}\text { Eq. } \\
\text { Var. }\end{array}$ & Definition & $\begin{array}{l}\text { Control } \\
\text { File }\end{array}$ & $\begin{array}{l}\text { Eq. } \\
\text { Var. }\end{array}$ & Definition \\
\hline not used & $F_{1}$ & $\begin{array}{l}\text { total weighted } \\
\text { food for } \\
\text { zooplankton, } \\
\mathrm{g} / \mathrm{m}^{3}\end{array}$ & FEREL & $x_{4}$ & $\begin{array}{l}\text { sediment iron release } \\
\text { rate, } g / \mathrm{m}^{2} \text { sec }\end{array}$ \\
\hline NH3DK & $K_{\mathbf{a}}$ & $\begin{array}{l}\text { ammonia- } \\
\text { nitrogen decay } \\
\text { rate, } \sec ^{-1}\end{array}$ & ZS2P & $Z_{1 / 2}$ & $\begin{array}{l}\text { half-saturation coeff. for } \\
\text { zooplankton ingestion, } \\
\mathrm{g} / \mathrm{m}^{\mathbf{3}}\end{array}$ \\
\hline COLDK & $\mathrm{K}_{\mathrm{c}}$ & $\begin{array}{l}\text { coliform death } \\
\text { rate, } \mathrm{sec}^{-1}\end{array}$ & ZEFFIC & $Z_{e}$ & $\begin{array}{l}\text { zooplankton ingestion } \\
\text { efficiency }\end{array}$ \\
\hline LABDK & $K_{d}$ & $\begin{array}{l}\text { liable DOM } \\
\text { decay rate, } \mathrm{sec}^{-1}\end{array}$ & ZOOMIN & $Z_{L}$ & $\begin{array}{l}\text { low threshold } \\
\text { concentration for } \\
\text { zooplankton feeding, } \\
\mathrm{g} / \mathrm{m}^{3}\end{array}$ \\
\hline DETDK & $K_{d t}$ & $\begin{array}{l}\text { detritus decay } \\
\text { rate, } \mathrm{sec}^{-1}\end{array}$ & not used & $\beta$ & $\begin{array}{l}\text { adsorption increment for } \\
\text { Iron }\end{array}$ \\
\hline AEXCR & $\mathrm{K}_{\mathrm{e}}$ & $\begin{array}{l}\text { algal excretion } \\
\text { rate, } \sec ^{-1}\end{array}$ & $\mathrm{H}$ & $\Delta Z$ & cell thickness, m \\
\hline AGROW & $\mathrm{K}_{\mathrm{g}}$ & $\begin{array}{l}\text { algal growth } \\
\text { rate, } \sec ^{-1}\end{array}$ & $\mathrm{BIOC}$ & $\delta_{c}$ & $\begin{array}{l}\text { stoichiometric coeff. for } \\
\text { carbon }\end{array}$ \\
\hline AMORT & $K_{m}$ & $\begin{array}{l}\text { algal mortality } \\
\text { rate, } \sec ^{-1}\end{array}$ & BION & $\delta_{\mathrm{N}}$ & $\begin{array}{l}\text { stoichiometric coeff. for } \\
\text { nitrogen }\end{array}$ \\
\hline ZMAX & $\mathrm{K}_{\max }$ & $\begin{array}{l}\text { max. ingestion } \\
\text { rate for } \\
\text { zooplankton, } \mathrm{hr}^{-1}\end{array}$ & $\begin{array}{l}\text { O2ALG } \\
\text { O2NH3 } \\
\text { O2DET } \\
\text { O2LAB }\end{array}$ & $\delta_{o i}$ & $\begin{array}{l}\text { stoichiometric } \\
\text { coefficients for oxygen }\end{array}$ \\
\hline NO3DK & $K_{n}$ & $\begin{array}{l}\text { nitrate-nitrogen } \\
\text { decay rate, } \sec ^{-1}\end{array}$ & O2RESP & $\delta_{\mathbf{o z}}$ & $\begin{array}{l}\text { stoichiometric coeff. } \\
\text { between biological } \\
\text { constituents and } \mathrm{O}_{2} \text { for } \\
\text { respiration }\end{array}$ \\
\hline REFDK & $K_{\mathbf{r}}$ & $\begin{array}{l}\text { refractory DOM } \\
\text { decay rate, } \mathrm{sec}^{-1}\end{array}$ & BIOP & $\delta_{\mathbf{P}}$ & $\begin{array}{l}\text { stoichiometric coeff. for } \\
\text { phosphorus }\end{array}$ \\
\hline ARESP & $\mathrm{K}_{\mathrm{rs}}$ & $\begin{array}{l}\text { algal dark } \\
\text { respiration rate, } \\
\sec ^{-1}\end{array}$ & iiiDT1 & $\gamma_{18}$ & $\begin{array}{l}\text { temperature rate } \\
\text { multiplier for ascending } \\
\text { portion of the curve }\end{array}$ \\
\hline SEDDK & $\mathrm{K}_{\mathrm{s}}$ & $\begin{array}{l}\text { sediment decay } \\
\text { rate, } \sec ^{-1}\end{array}$ & iiiDT3 & $\gamma_{28}$ & $\begin{array}{l}\text { temperature rate } \\
\text { multiplier for descending } \\
\text { portion of the curve }\end{array}$ \\
\hline
\end{tabular}




\begin{tabular}{|c|c|c|c|c|c|}
\hline $\begin{array}{l}\text { Control } \\
\text { File }\end{array}$ & $\begin{array}{l}\text { Eq. } \\
\text { Var. }\end{array}$ & Definition & $\begin{array}{l}\text { Control } \\
\text { File }\end{array}$ & $\begin{array}{l}\text { Eq. } \\
\text { Var. }\end{array}$ & Definition \\
\hline LRFDK & $K_{1}$ & $\begin{array}{l}\text { transfer rate } \\
\text { from liable to } \\
\text { refractory DOM, } \\
\sec ^{-1}\end{array}$ & $\begin{array}{l}\text { iiiDT2 } \\
\text { iiiDT4 }\end{array}$ & $\gamma_{\mathbf{i i}}$ & $\begin{array}{l}\text { temperature rate } \\
\text { multipliers }\end{array}$ \\
\hline not used & $\mathrm{K}_{\mathrm{zi}}$ & $\begin{array}{l}\text { zooplankton } \\
\text { ingestion rate, } \\
\mathrm{hr}^{-1}\end{array}$ & not used & $\theta$ & temperature factor \\
\hline ZMORT & $\mathrm{K}_{\mathrm{zm}}$ & $\begin{array}{l}\text { zooplankton } \\
\text { mortality rate, } \mathrm{hr}^{-}\end{array}$ & SSETL1 & $\omega_{1}$ & $\begin{array}{l}\text { inorganic suspended } \\
\text { solids settling velocity for } \\
\text { smallest particles, m/day }\end{array}$ \\
\hline ZRESP & $\mathrm{K}_{\mathrm{zr}}$ & $\begin{array}{l}\text { zooplankton } \\
\text { respiration rate, } \\
\mathrm{hr}^{-1}\end{array}$ & DSETL & $\omega_{2}$ & $\begin{array}{l}\text { detritus settling velocity, } \\
\mathrm{m} / \mathrm{sec}\end{array}$ \\
\hline DETDK & $K_{b}$ & $\begin{array}{l}\text { CBOD decay } \\
\text { rate, } \sec ^{-1}\end{array}$ & ASETL & $\omega_{3}$ & $\begin{array}{l}\text { algal settling velocity, } \\
\mathrm{m} / \mathrm{sec}\end{array}$ \\
\hline SSETL2 & $\omega_{6}$ & $\begin{array}{l}\text { inorganic } \\
\text { suspended } \\
\text { solids settling } \\
\text { rate, } \mathrm{m} / \text { day }\end{array}$ & SSETL5 & $\omega_{9}$ & $\begin{array}{l}\text { inorganic suspended } \\
\text { solids settling rate for } \\
\text { 2nd to largest particles, } \\
\text { m/day }\end{array}$ \\
\hline SSETL3 & $\omega_{7}$ & $\begin{array}{l}\text { inorganic } \\
\text { suspended } \\
\text { solids settling } \\
\text { rate, } \mathrm{m} / \text { day }\end{array}$ & SSETL6 & $\omega_{10}$ & $\begin{array}{l}\text { inorganic suspended } \\
\text { solids settling rate for } \\
\text { largest particles, m/day }\end{array}$ \\
\hline SSETL4 & $\omega_{8}$ & $\begin{array}{l}\text { inorganic } \\
\text { suspended } \\
\text { solids settling } \\
\text { rate, } \mathrm{m} / \text { day }\end{array}$ & FESETL & $\omega_{4}$ & $\begin{array}{l}\text { Iron settling velocity, } \\
\mathrm{m} / \mathrm{sec}\end{array}$ \\
\hline
\end{tabular}




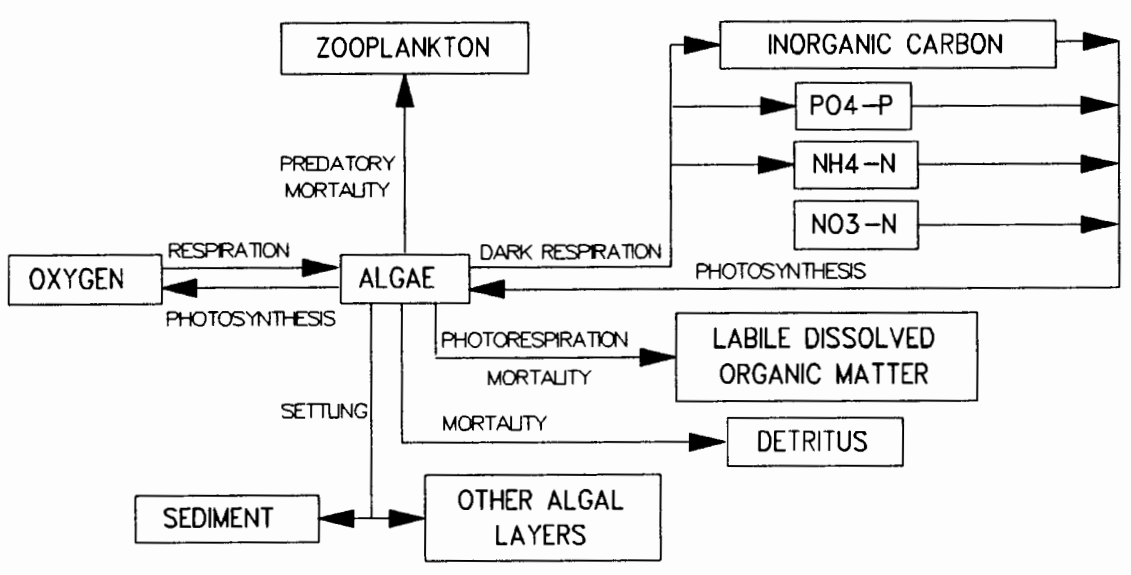

Figure A.1. Algae Sources and Sinks.

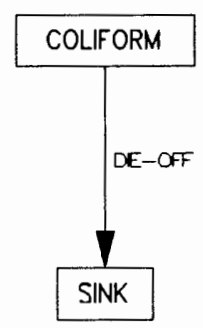

Figure A.2. Coliform first-order decay process. 


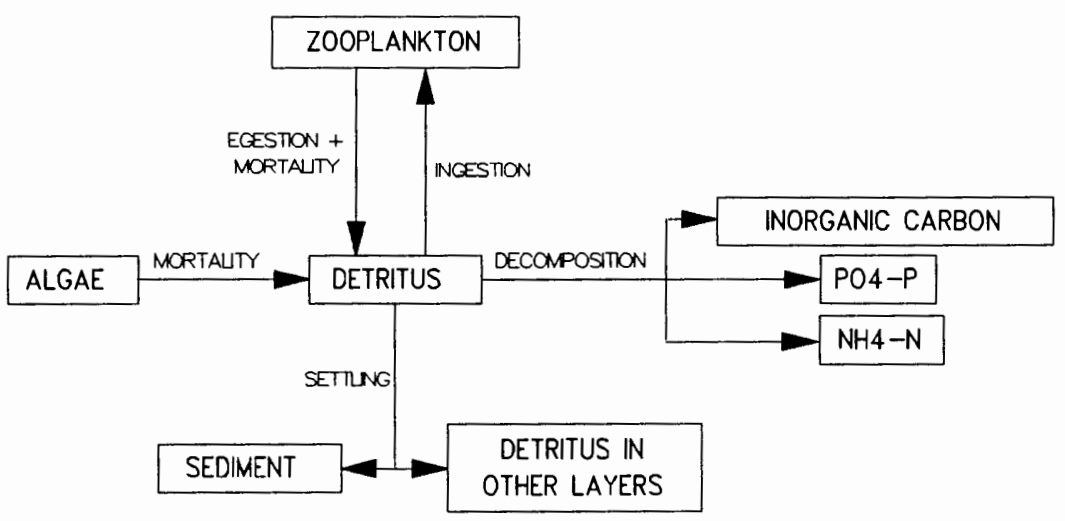

Figure A.3. Detritus sources and sinks.

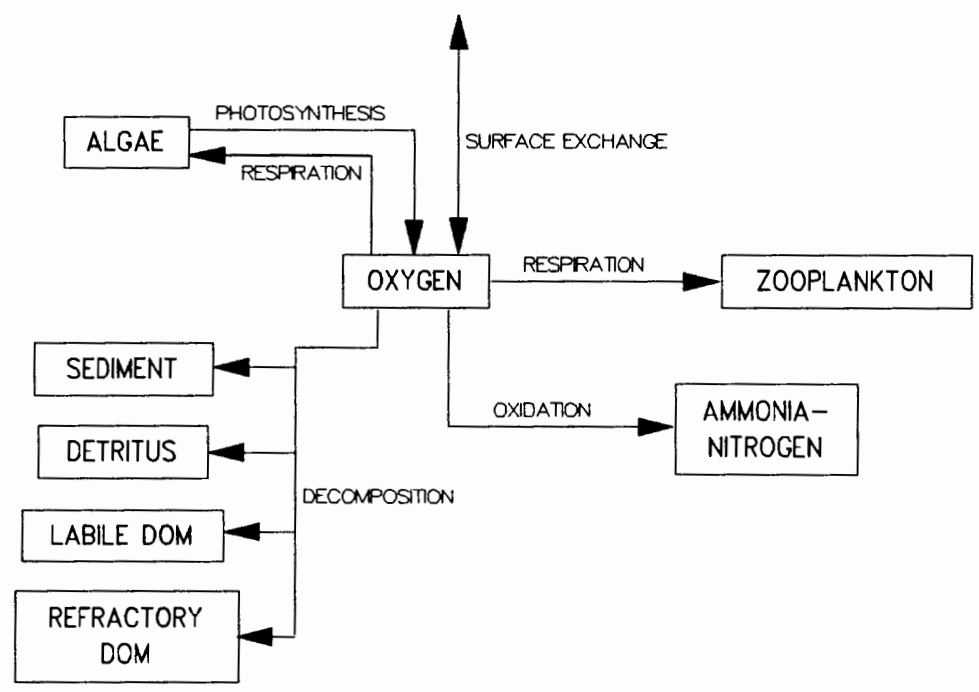

Figure A.4. Dissolved Oxygen sources and sinks. 


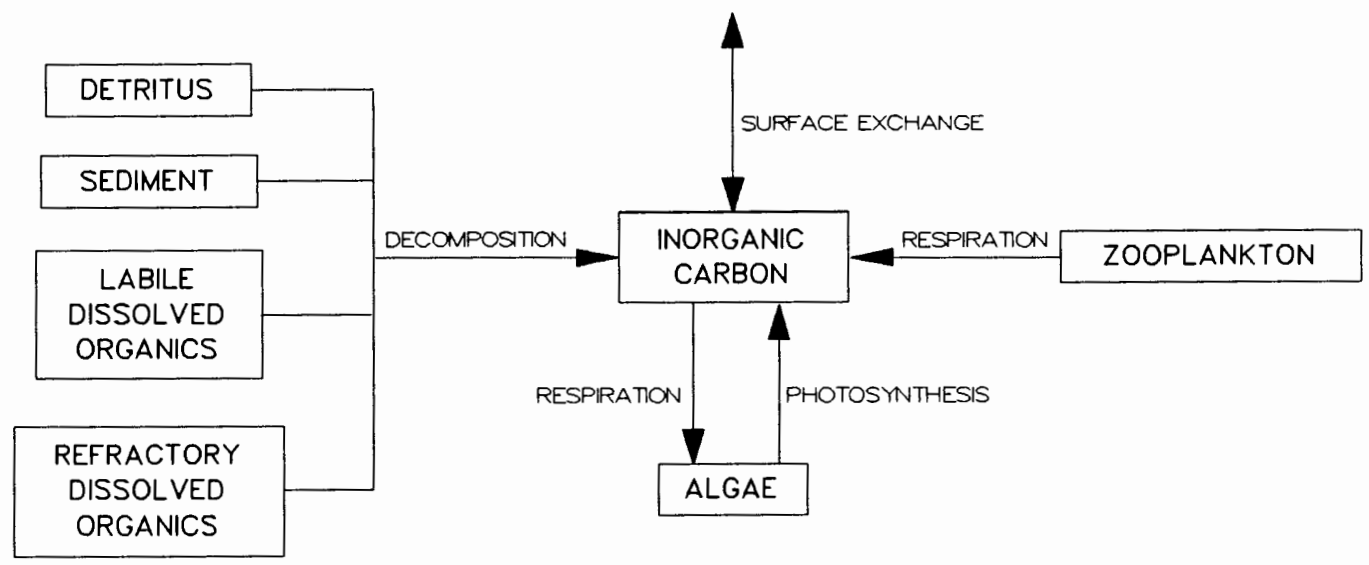

Figure A.5. Inorganic Carbon sources and sinks.

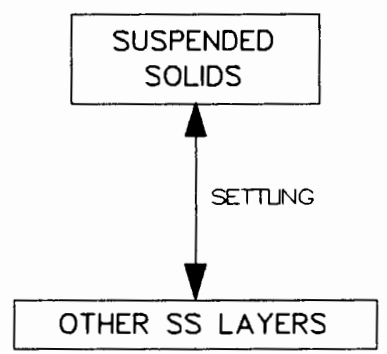

Figure A.6. Inorganic suspended solids sedimentation. 


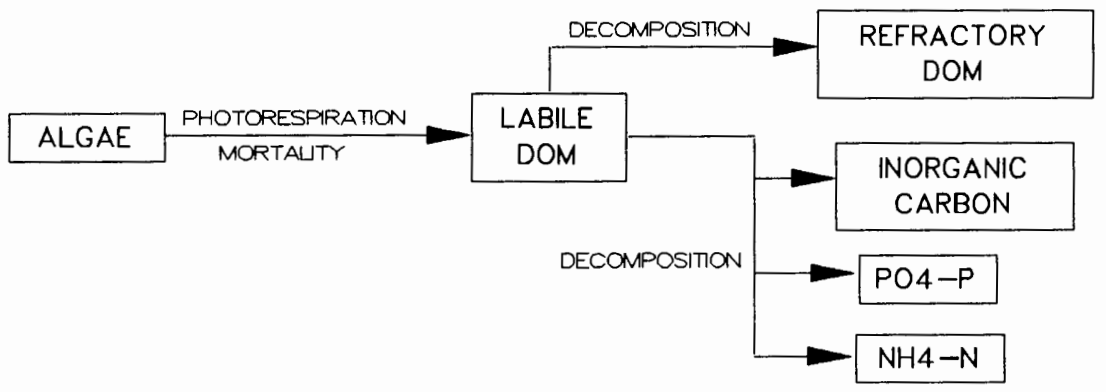

Figure A.7. Labile dissolved organic matter sources and sinks.

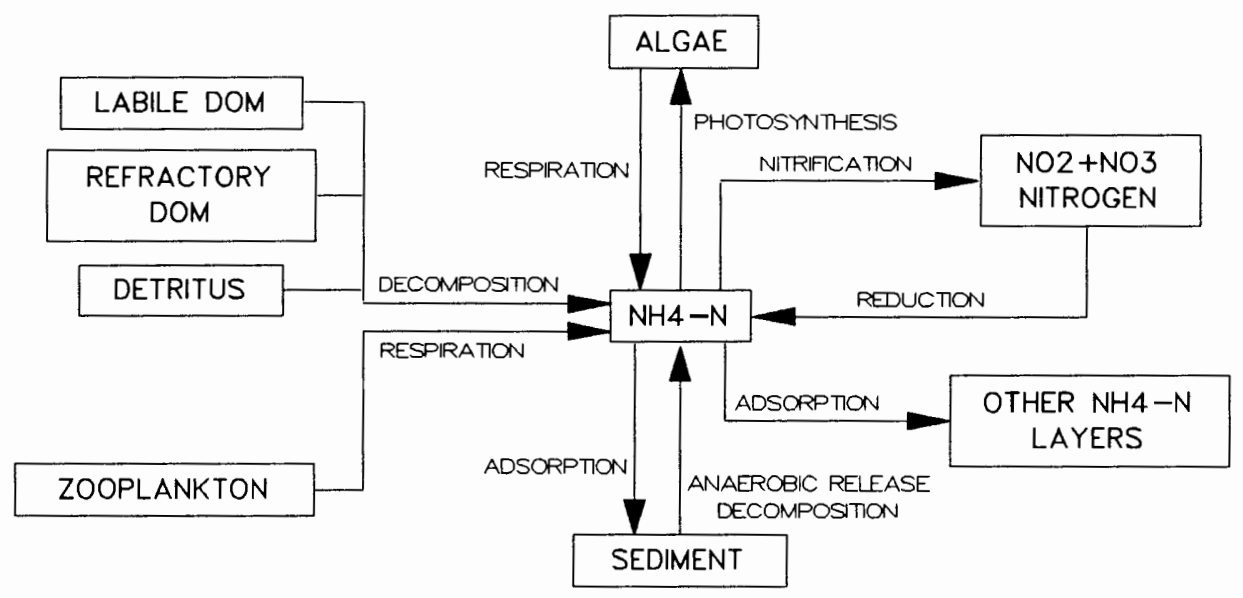

Figure A.8. Ammonia-N sources and sinks. 


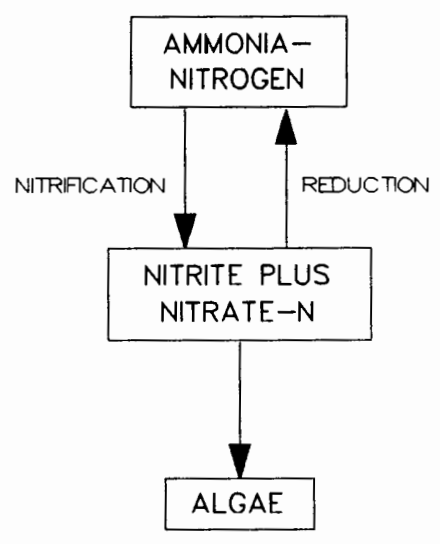

Figure A.9. Nitrite \& Nitrate sources and sinks.

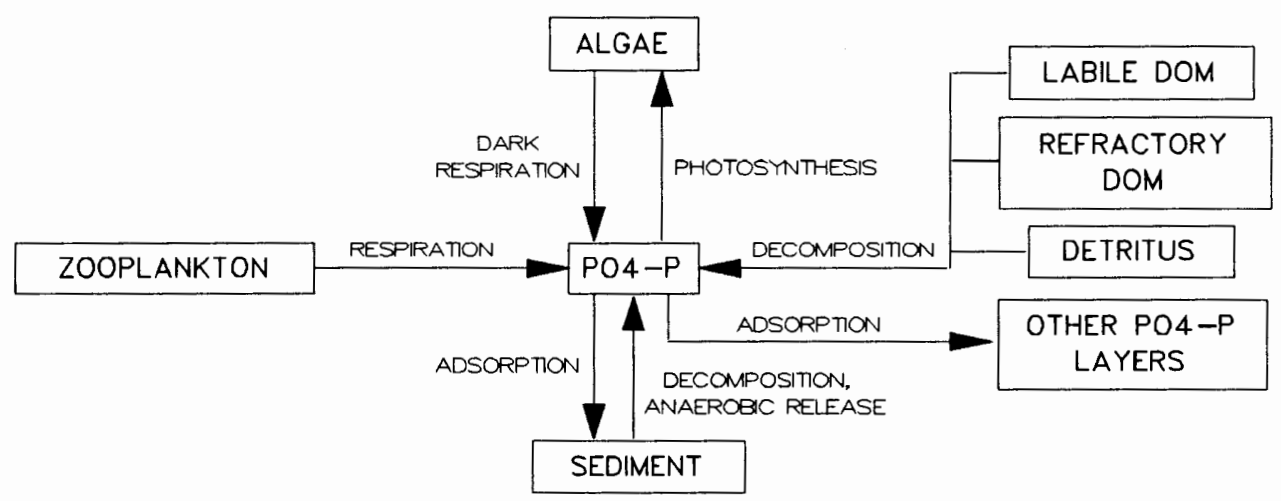

Figure A.10. Ortho-phosphorus sources and sinks. 


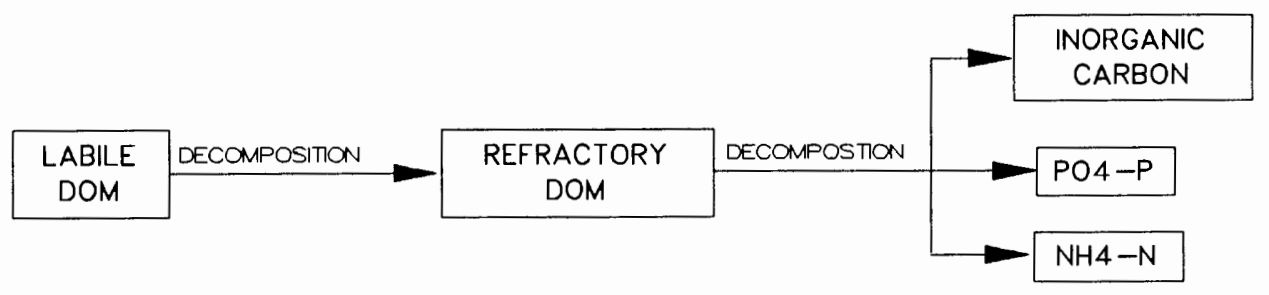

Figure A.11. Refractory dissolved organic matter sources and sinks.

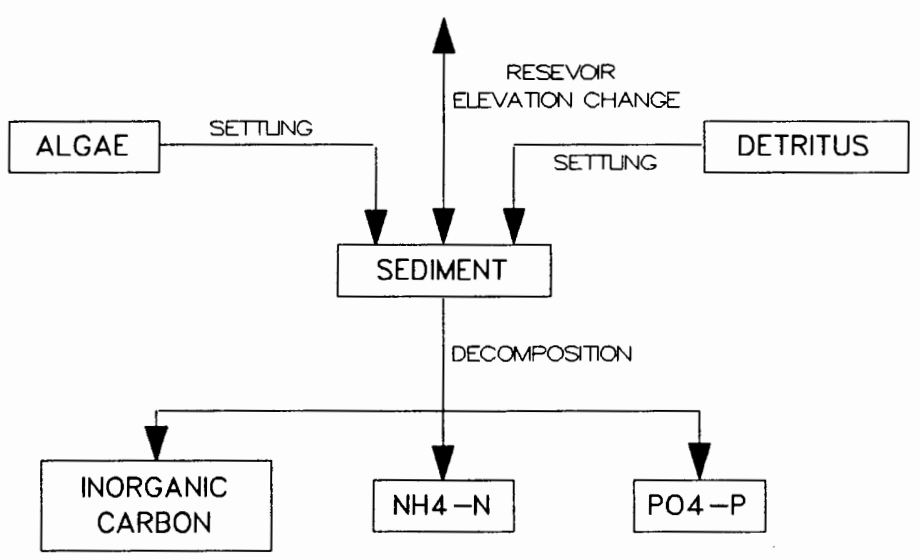

Figure A.12. Sediment accumulation/deposition. 


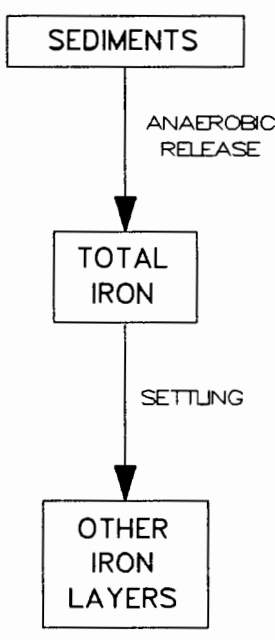

Figure A.13. Total iron sources and sinks.

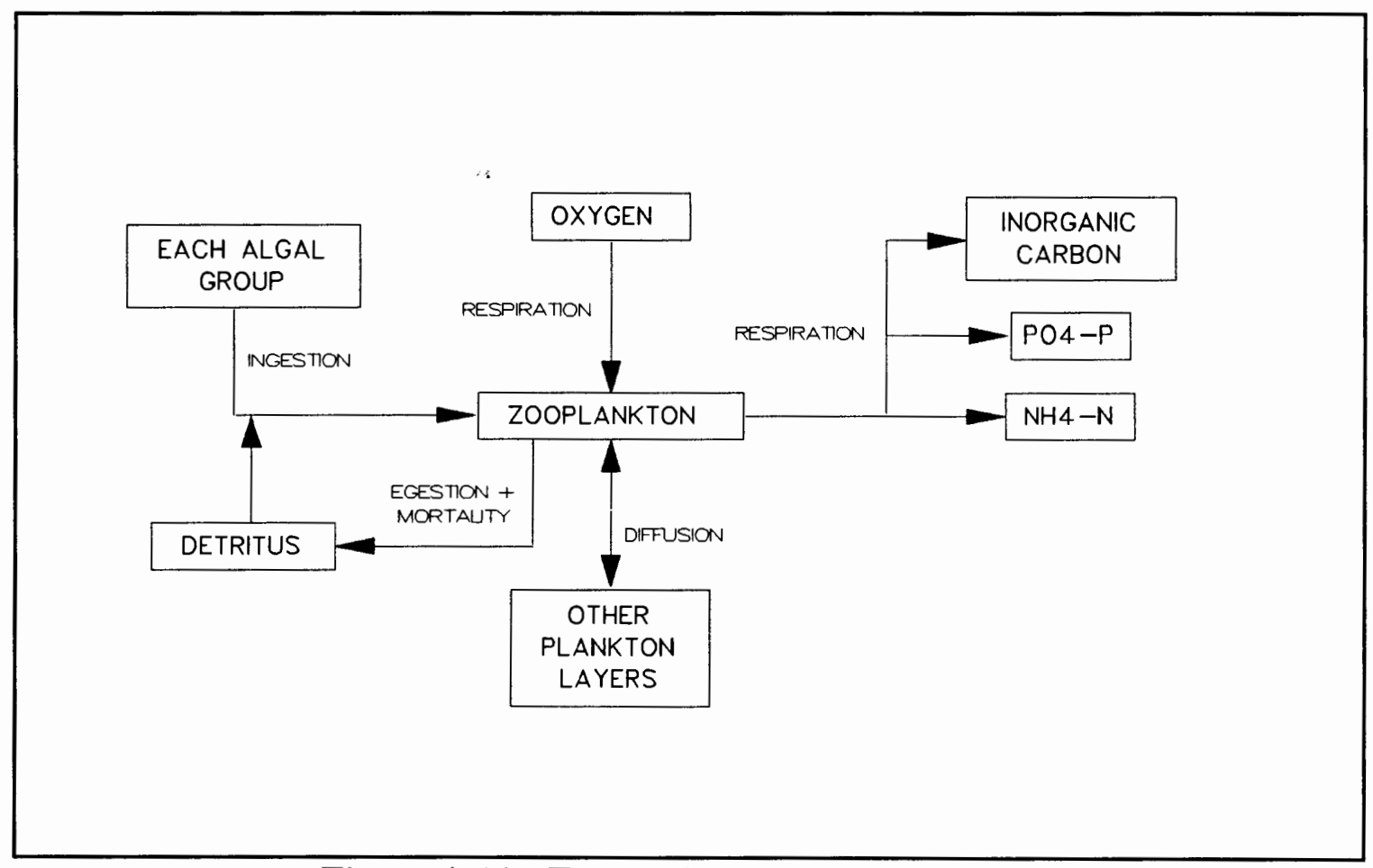

Figure A.14. Zooplankton sources and sinks. 
APPENDIX B

BATHYMETRY FOR HAGG LAKE 
The cross-sections for each longitudinal cell described in Chapter IV are included in this appendix. Figure B.1 shows the cell widths (m) for each cell in the Hagg Lake model as described in Figure 7. 


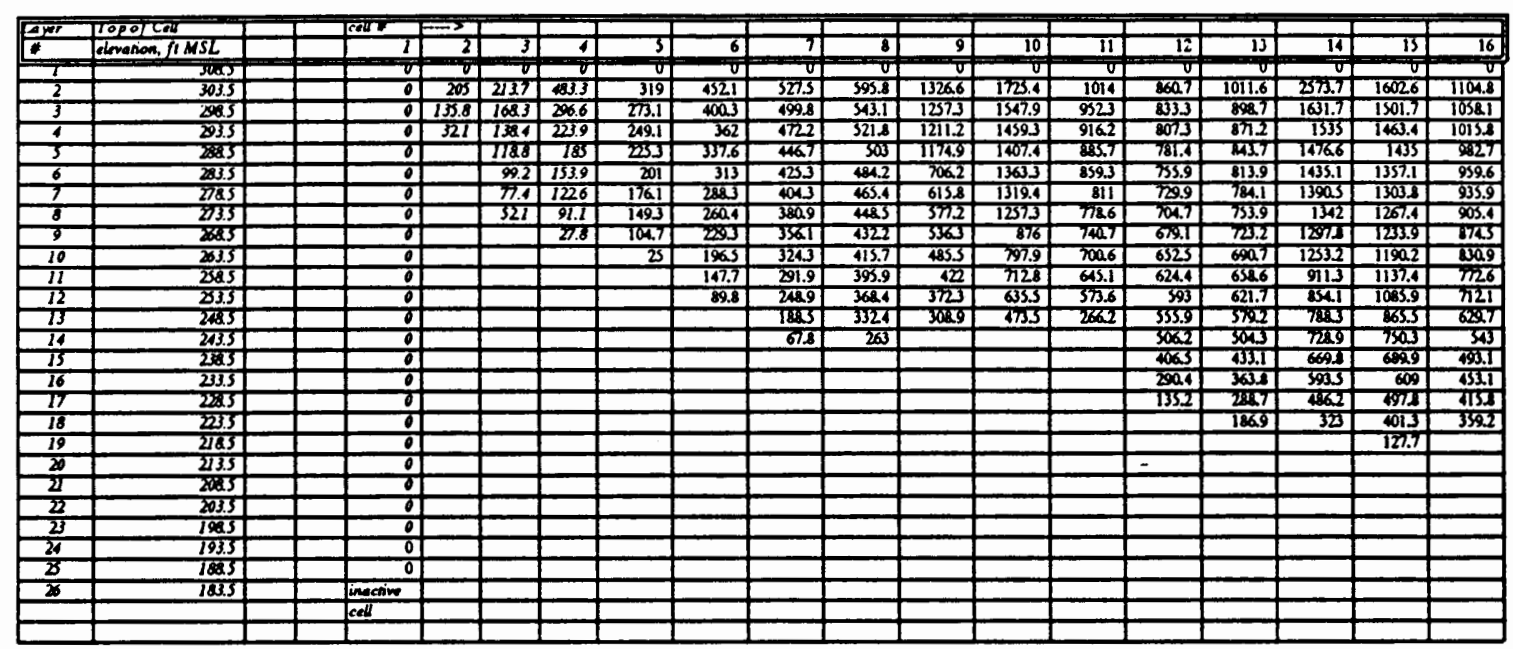

CELL WIDTHS FOR HAGG LAKE . TUALATIN RVER MODEL (CONT.)

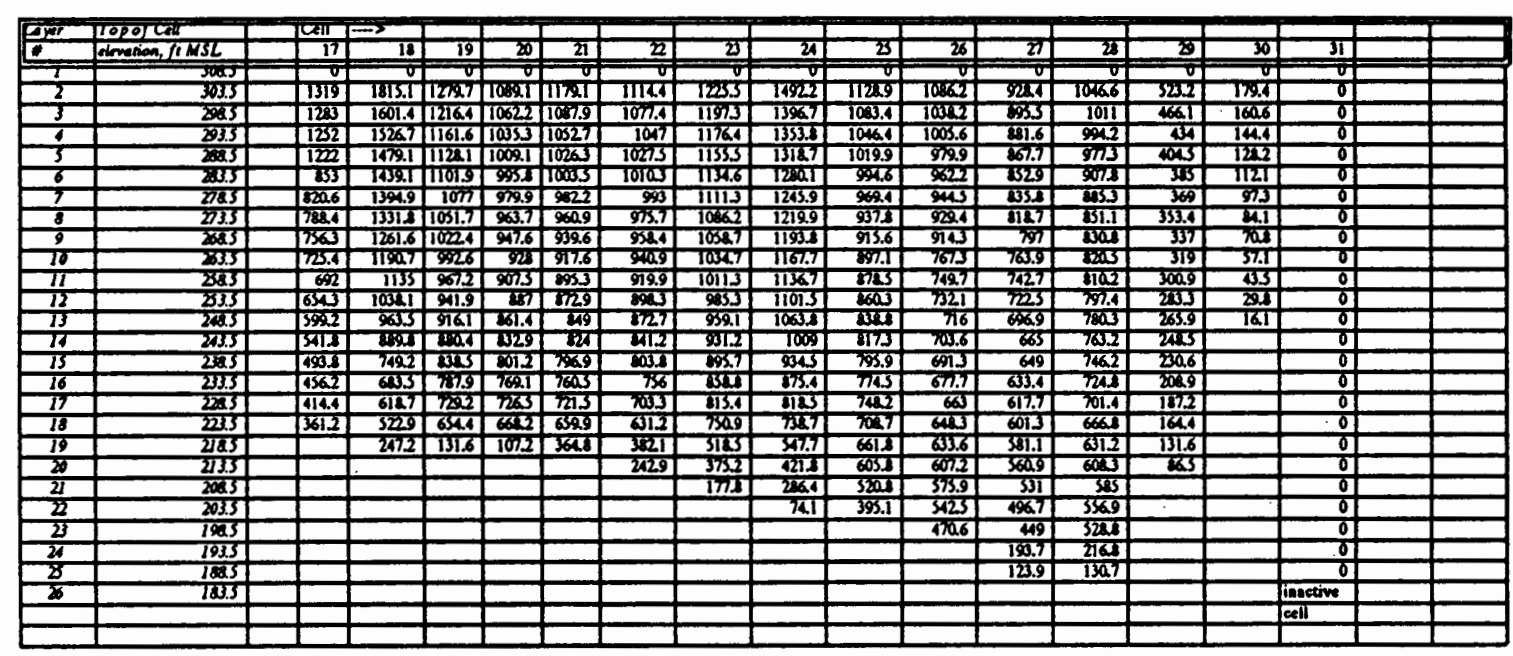

Figure B.1. Cell Widths for Hagg Lake. 
APPENDIX C

HAGG LAKE MODEL FILE DESCRIPTION 
This Appendix is intended to show the organization of files used in the Hagg Lake model, their description and their use. Table $\mathrm{C}-1$ reviews the files used for the Hagg Lake model. Filenames are listed for the model prior to additional particle size additions ("1") and after additional particle size additions ("2"). The files listed are for the 1990 Hagg Lake model. Files used for the 1991 period have the same descriptions, but they are dated "91" rather than "90".

TABLE $C-1$

ORGANIZATION OF FILES USED IN THE ORIGINAL HAGG LAKE MODEL

\begin{tabular}{|c|c|c|}
\hline Type of File & $\begin{array}{l}\text { File Name } \\
\text { "1" = Original } \\
\text { "2" = S. S. } \\
\text { Additions }\end{array}$ & File Description \\
\hline $\begin{array}{l}\text { Main Control } \\
\text { File }\end{array}$ & $\begin{array}{l}\text { 1. hagg_con.npt } \\
\text { 2. hgss_con.npt }\end{array}$ & $\begin{array}{l}\text { control file with run } \\
\text { information, } \\
\text { input/output file map, } \\
\text { model coefficients, etc. }\end{array}$ \\
\hline $\begin{array}{l}\text { Bathymetry } \\
\text { File }\end{array}$ & $\begin{array}{l}\text { 1. hlbth.npt } \\
\text { 2. hlbth.npt }\end{array}$ & $\begin{array}{l}\text { cell widths, cell } \\
\text { heights, initial water } \\
\text { surface profile, and } \\
\text { Mannings friction factor } \\
\text { for each longitudinal } \\
\text { cell }\end{array}$ \\
\hline $\begin{array}{l}\text { Meteorologic } \\
\text { File }\end{array}$ & $\begin{array}{l}\text { 1. met } 90 . n p t \\
2 . \operatorname{met} 90 . n p t\end{array}$ & $\begin{array}{l}\text { daily averaged values of } \\
\text { air temperature, dew- } \\
\text { point temperature, wind } \\
\text { speed, wind direction, } \\
\text { and cloud cover }\end{array}$ \\
\hline \multirow[t]{2}{*}{$\begin{array}{l}\text { Branch } \\
\text { Inflow Files }\end{array}$} & $\begin{array}{l}\text { 1. qtr1_90.npt } \\
\text { 2. qtr1_90.npt }\end{array}$ & $\begin{array}{l}\text { flow rates }\left(\mathrm{m}^{3} / \mathrm{s}\right) \text { as a } \\
\text { function of Julian day } \\
\text { for Scoggins Creek } \\
\text { (long. cell 2) }\end{array}$ \\
\hline & $\begin{array}{l}\text { 1. } \operatorname{trr} 1 \_90 . \mathrm{npt} \\
\text { 2. } \operatorname{tr} 1-90 . \mathrm{npt}\end{array}$ & $\begin{array}{l}\text { temperature }\left({ }^{\circ} \mathrm{C}\right) \text { as a } \\
\text { function of Julian day } \\
\text { for Scoggins Creek }\end{array}$ \\
\hline
\end{tabular}




\begin{tabular}{|c|c|c|}
\hline \multirow[t]{2}{*}{ Type of File } & $\begin{array}{l}\text { File Name } \\
\text { "1" = Original } \\
\text { "2" = S. S. } \\
\text { Additions }\end{array}$ & File Description \\
\hline & $\begin{array}{l}\text { 1. ctr1_90.npt } \\
\text { 2. css1_90.npt }\end{array}$ & $\begin{array}{l}\text { water quality } \\
\text { constituent } \\
\text { concentrations for } \\
\text { Scoggins Creek as a } \\
\text { function of Julian day }\end{array}$ \\
\hline \multirow[t]{3}{*}{$\begin{array}{l}\text { Tributary } \\
\text { Inflow Files }\end{array}$} & $\begin{array}{l}\text { 1. qtr2-90.npt } \\
\text { 2. qtr2-90.npt } \\
\text { 1. qtr3-90.npt } \\
\text { 2. qtr3-90.npt }\end{array}$ & $\begin{array}{l}\text { flow rates }\left(\mathrm{m}^{3} / \mathrm{s}\right) \text { as a } \\
\text { function of Julian day } \\
\text { for Sain ( } 2) \text { (long. cell } \\
9) \text { and Tanner ( } 3) \text { (long. } \\
\text { cell 14) Creeks }\end{array}$ \\
\hline & $\begin{array}{l}\text { 1. } \operatorname{tr2} 290 . \mathrm{npt} \\
\text { 2. ttr2-90.npt } \\
\text { 1. ttr3-90.npt } \\
\text { 2. ttr3-90.npt }\end{array}$ & $\begin{array}{l}\text { temperature }\left({ }^{\circ} \mathrm{C}\right) \text { as a } \\
\text { function of Julian day } \\
\text { for Sain (2) and Tanner } \\
\text { (3) Creeks }\end{array}$ \\
\hline & $\begin{array}{l}\text { 1. ctr2_90.npt } \\
\text { 2. css2-90.npt } \\
\text { 1. ctr3-90.npt } \\
\text { 2. css3_90.npt }\end{array}$ & $\begin{array}{l}\text { water quality } \\
\text { constituent } \\
\text { concentrations for Sain } \\
\text { (2) and Tanner ( } 3 \text { ) } \\
\text { Creeks as a function of } \\
\text { Julian day }\end{array}$ \\
\hline Outflow File & $\begin{array}{l}\text { 1. hlout_90.npt } \\
\text { 2. hlout_90.npt }\end{array}$ & $\begin{array}{l}\text { downstream outflow file } \\
\text { for spillway flows (none } \\
\text { in study) }\end{array}$ \\
\hline $\begin{array}{l}\text { Withdrawal } \\
\text { File }\end{array}$ & $\begin{array}{l}\text { 1. hlwd_90.npt } \\
\text { 2. hlwd_90.npt }\end{array}$ & $\begin{array}{l}\text { withdrawal file for } \\
\text { Scoggins Dam withdrawals } \\
\text { (long. cell } 29, \text { vert. } \\
\text { cells } 14-16)\left(\mathrm{m}^{3} / \mathrm{s}\right) \text { as a } \\
\text { function of Julian day }\end{array}$ \\
\hline $\begin{array}{l}\text { FORTRAN } \\
\text { Source Code }\end{array}$ & $\begin{array}{l}\text { 1. w2hagg.for } \\
\text { 2. w2hg_ss.for }\end{array}$ & $\begin{array}{l}\text { CE-QUAL-W2 model code } \\
\text { with updates and } \\
\text { modifications }\end{array}$ \\
\hline Output Files & $\begin{array}{l}\text { 1. conc_out.opt } \\
\text { 2. conc_3.opt } \\
\text { 2. conc-9.opt } \\
\text { 2. conc-14.opt } \\
\text { 2. conc_22.opt } \\
\text { 2. conc_out.opt }\end{array}$ & $\begin{array}{l}\text { Concentrations at: } \\
\text { outlet, cell } 3, \text { cell } 9 \text {, } \\
\text { cell } 14, \text { and cell } 22 \text { of } \\
\text { active water quality } \\
\text { constituents as a } \\
\text { function of Julian day } \\
\text { (every } 400 \text { time steps) }\end{array}$ \\
\hline
\end{tabular}




\begin{tabular}{|c|c|c|}
\hline \multirow[t]{6}{*}{ Type of File } & $\begin{array}{l}\text { File Name } \\
\text { "1" = Original } \\
" 2 "=\text { S. S. } \\
\text { Additions }\end{array}$ & File Description \\
\hline & $\begin{array}{l}\text { 1. snp.opt } \\
\text { 2. snp.opt }\end{array}$ & $\begin{array}{l}\text { Output summary file: } \\
\text { concentrations, } \\
\text { temperatures, } \\
\text { velocities, limiting } \\
\text { factors, etc. as a } \\
\text { function of frequency } \\
\text { requested. }\end{array}$ \\
\hline & $\begin{array}{l}\text { 1. temp.out } \\
\text { 2. temp.out }\end{array}$ & $\begin{array}{l}\text { Temperature at outlet as } \\
\text { function of Julian day }\end{array}$ \\
\hline & $\begin{array}{l}\text { 1. pro_const.out } \\
\text { 2. pro_const.out }\end{array}$ & $\begin{array}{l}\text { Profiles of all active } \\
\text { constituents and } \\
\text { temperature at long. } \\
\text { cell } 29\end{array}$ \\
\hline & $\begin{array}{l}\text { 1. violavg.opt } \\
\text { 2. violavg.opt }\end{array}$ & $\begin{array}{l}\text { average simulation } \\
\text { violation for D.O., pH, } \\
\text { and chlorophyll-a goals }\end{array}$ \\
\hline & $\begin{array}{l}\text { 1. violent.opt } \\
\text { 2. violent.opt }\end{array}$ & $\begin{array}{l}\text { plotable violation } \\
\text { histograms for D.O., pH, } \\
\text { and chlorophyll-a }\end{array}$ \\
\hline \multirow[t]{2}{*}{$\begin{array}{l}\text { Other Input } \\
\text { Files }\end{array}$} & $\begin{array}{l}\text { 1. outlet.npt } \\
2 \text {. outlet.npt }\end{array}$ & $\begin{array}{l}\text { Input file for outlet } \\
\text { intake structure } \\
\text { fractions (FRACT1, } \\
\text { FRACT2, and FRACT3) }\end{array}$ \\
\hline & $\begin{array}{l}\text { 1. pro_date.npt } \\
\text { 2. pro_date.npt }\end{array}$ & $\begin{array}{l}\text { Dates for profiles to be } \\
\text { output (Julian day) }\end{array}$ \\
\hline $\begin{array}{l}\text { Initial } \\
\text { Profile }\end{array}$ & $\begin{array}{l}\text { 1. vpr_90.npt } \\
\text { 2. vpr_91.npt }\end{array}$ & $\begin{array}{l}\text { Initial constituent } \\
\text { concentration profiles } \\
\text { on May lst }\end{array}$ \\
\hline Include File & $\begin{array}{l}\text { 1. w2 hg. inc } \\
\text { 2. w2 ss.inc }\end{array}$ & $\begin{array}{l}\text { Map file for CE-QUAL-W2 } \\
\text { source code }\end{array}$ \\
\hline
\end{tabular}


APPENDIX D

PLOTS OF SEDIMENTATION PROCESSES IN HAGG LAKE 
Using the software plotting program TECPLOT, concentrations of sediment particles for Hagg Lake were made during the 1990 sedimentation analysis period as described in Chapter VIII. Figure D.1 shows concentrations of particles in the SS1 category $(0.0002 \mathrm{~mm})$ for February 1st, March 1st, May 1st, June 1st, July 1st, and September 1, 1990. Figure D.2 shows concentrations of particles in the SS2 category $(0.0008$ mm) for February 1st, March 1st, May 1st, June 1st, July 1st, and september 1, 1990. Figure D.3 shows concentrations of particles in the SS3 category $(0.0014 \mathrm{~mm})$ for February 1st, March 1st, May 1st, June 1st, July 1st, and September 1, 1990. Figure D.4 shows concentrations of particles in the SS4 category $(0.002 \mathrm{~mm})$ for February 1st, March 1st, May 1st, June 1st, July 1st, and September 1, 1990. Figure D.5 shows concentrations of particles in the $5 S 5$ category $(0.010 \mathrm{~mm})$ for February 1st, March 1st, May 1st, June 1st, July 1st, and September 1, 1990. The SS6 category $(0.030 \mathrm{~mm})$ of particles was not plotted since these particles settled out of the water column too fast, and all plots were blank. 
SS1 - February 1, 1990

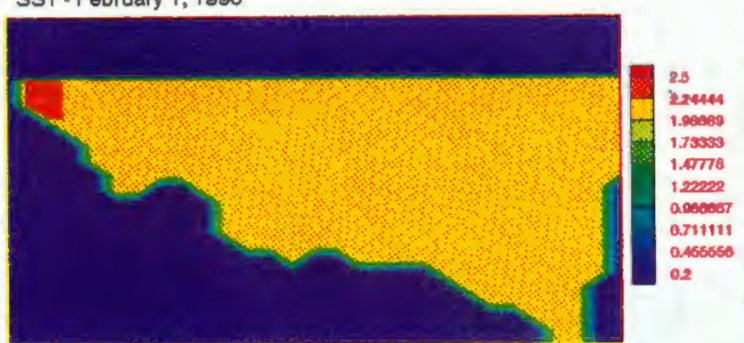

SS1 - May 1, 1990

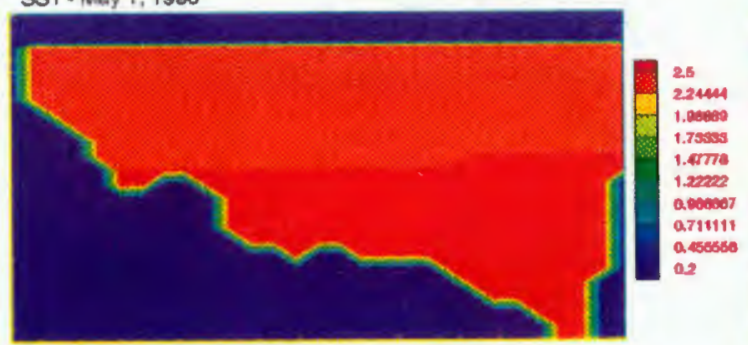

SS1- July 1, 1990
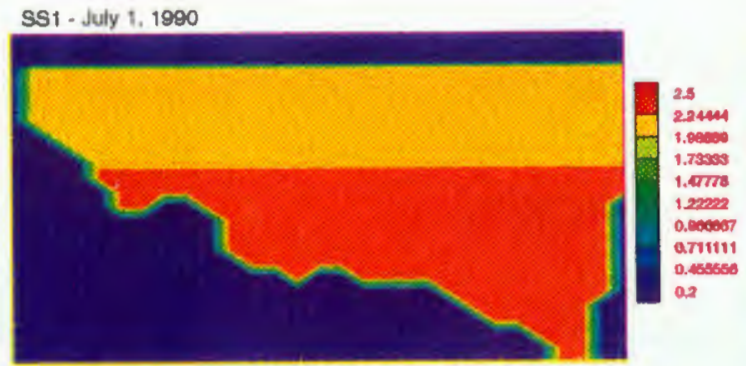

SS1 - March 1, 1990

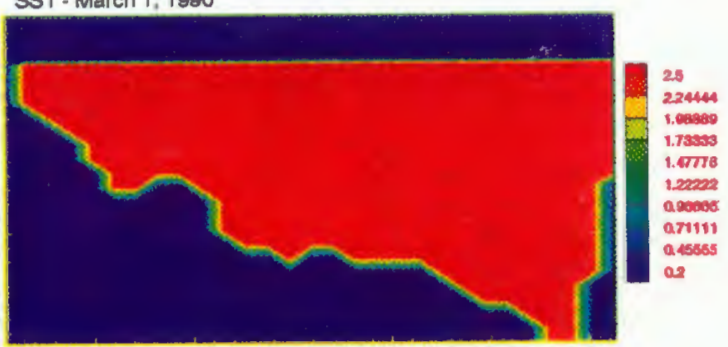

SS1 - June 4,1990

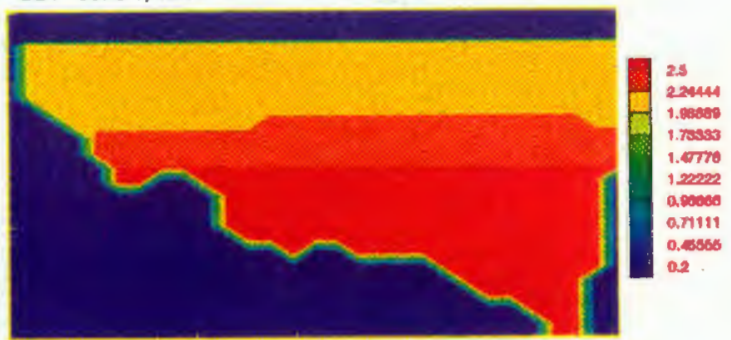

SS1 - September 1, 1990

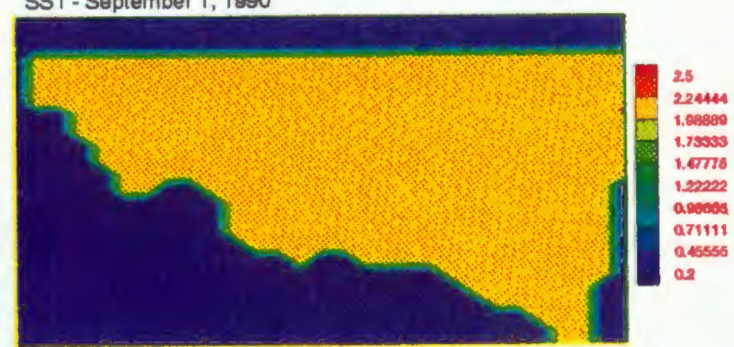

Figure D.1. SS1 suspended solid particle concentration (mg/1) on February 1st, March 1st, May 1st, June 1st, July 1st, and September 1, 1990. 

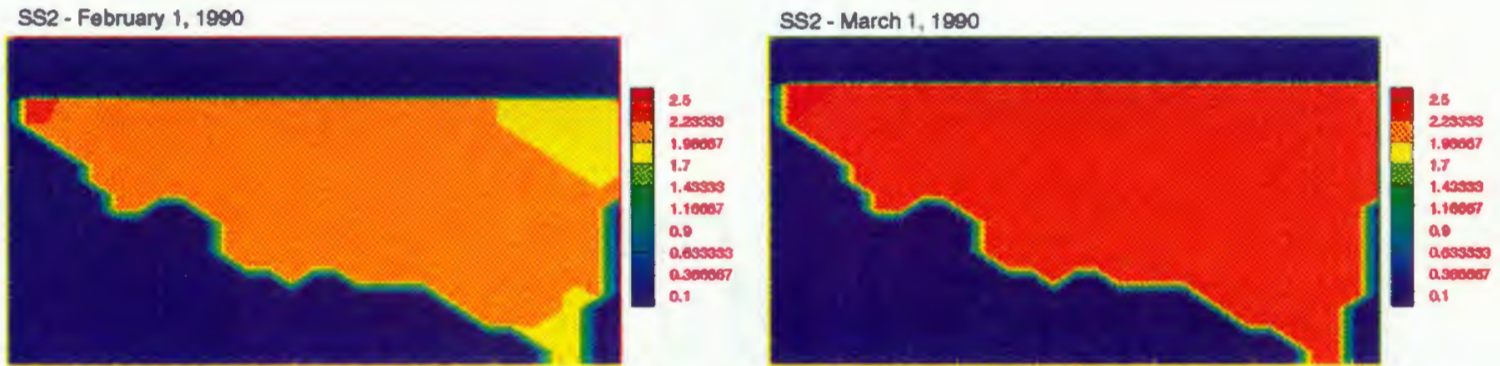

SS2. May 1, 1890
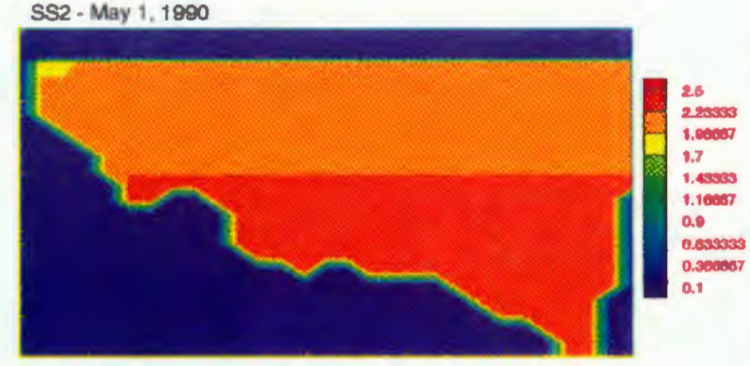

SS2 - July 1,1990

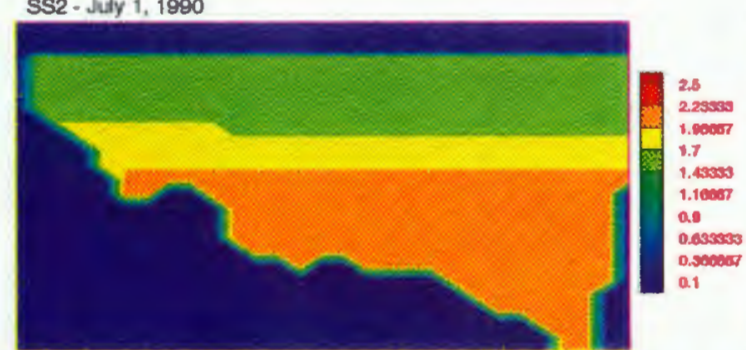

SS2 - June 1,1990

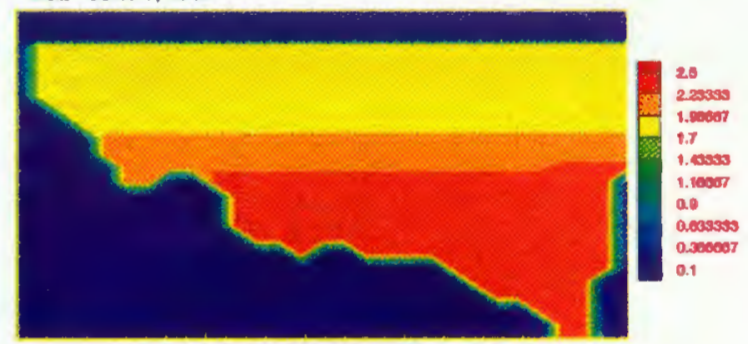

SS2 - September 1, 1990

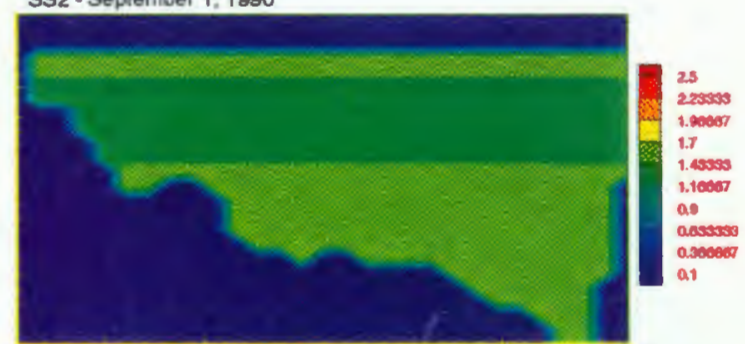

Figure D.2. SS2 suspended solid particle concentration $(\mathrm{mg} / \mathrm{l})$ on February 1st, March 1st, May 1st, June 1st, July 1st, and September 1, 1990. 

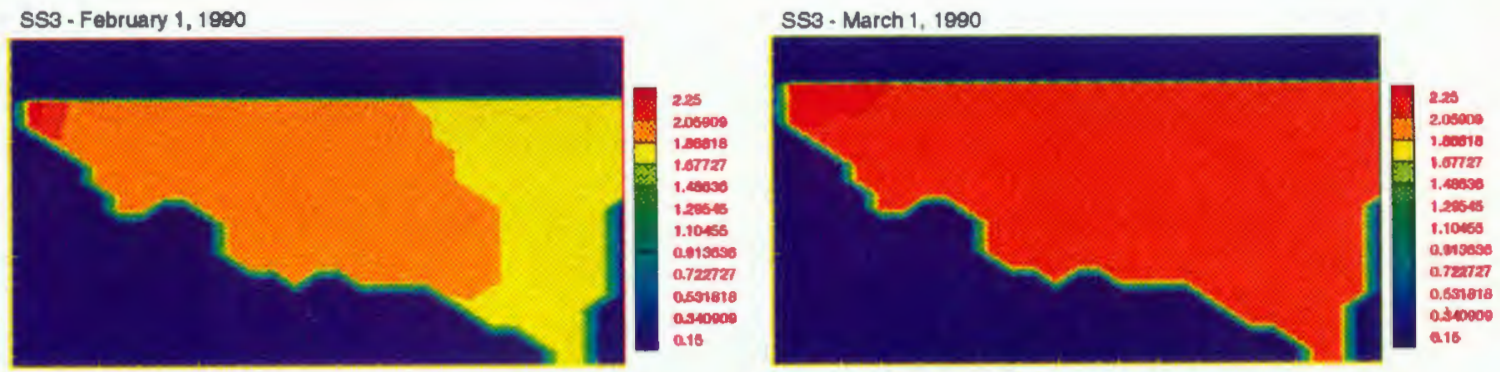

SS3 - May 1, 1990

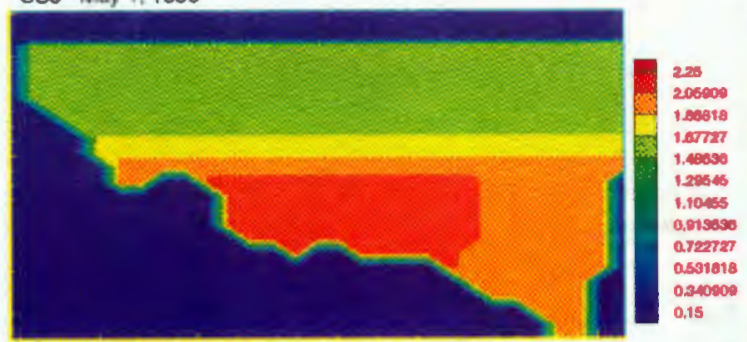

SS3 - July 1,1900
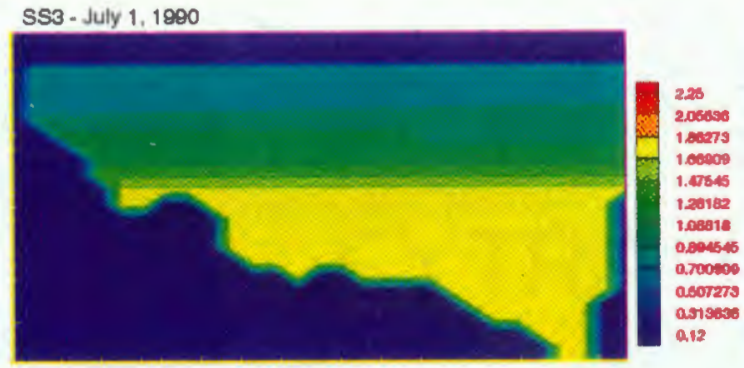

SS2 - June 1, 1990

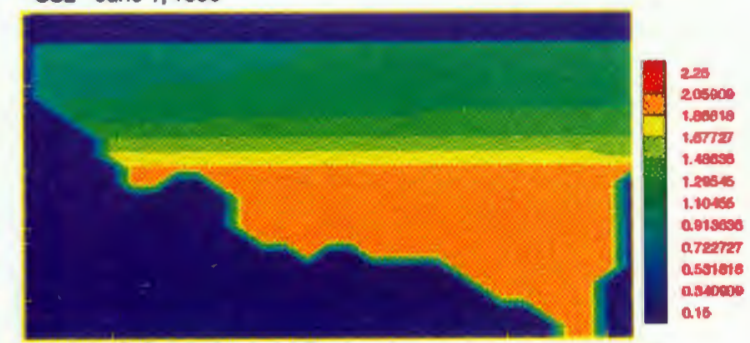

SS3 - September 1, 1990

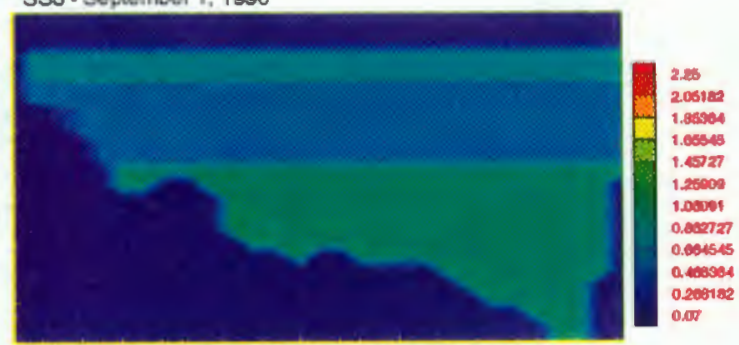

Figure D.3. SS3 suspended solid particle concentration $(\mathrm{mg} / \mathrm{l})$ on February 1st, March 1st, May 1st, June 1st, July 1st, and september 1, 1990. 
SS4. Fobruary 1,1990

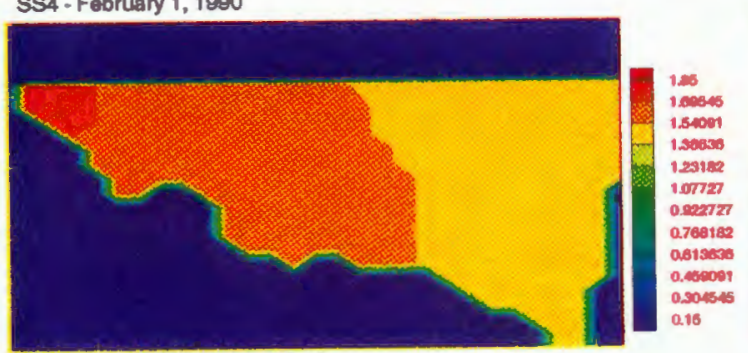

SS4 - May 1, 1890

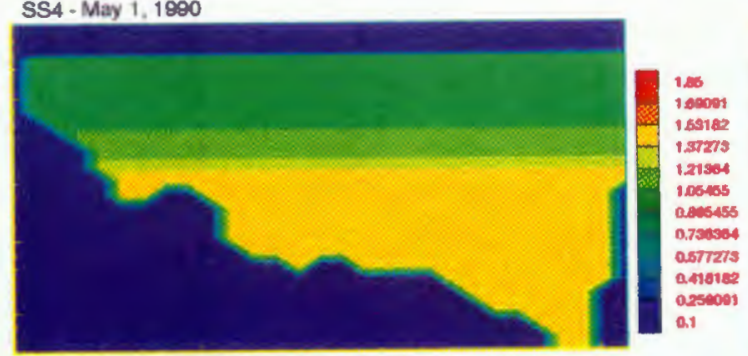

SS4 - July 1, 1990

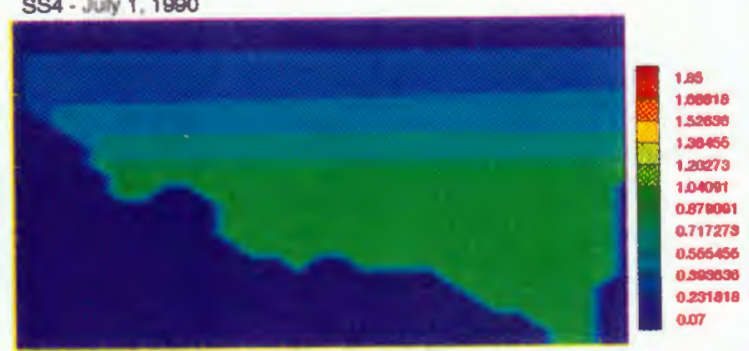

SS4 - March 1, 1990

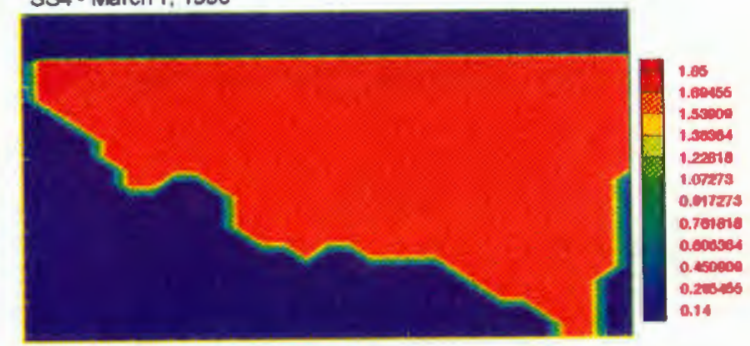

SS4 - June 1, 1990

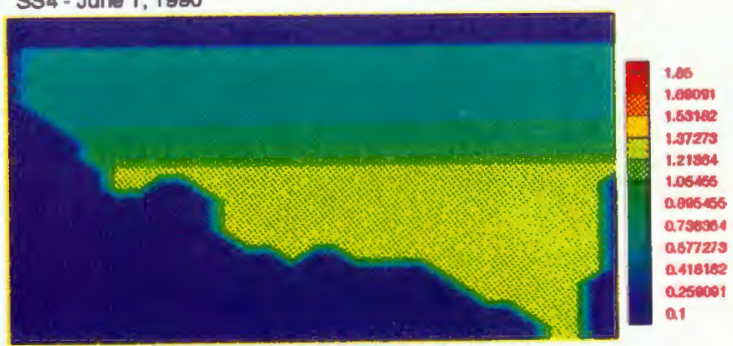

SS4 - September 1, 1990

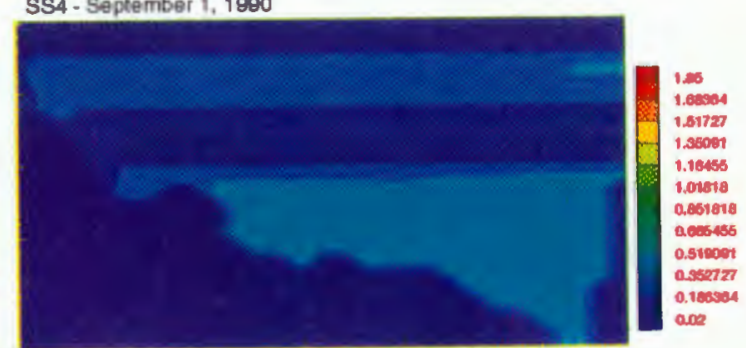

Figure D.4. SS4 suspended solid particle concentration (mg/1) on February 1st, March 1st, May 1st, June 1st, July 1st, and september 1, 1990. 
SS5 - February 1,1890

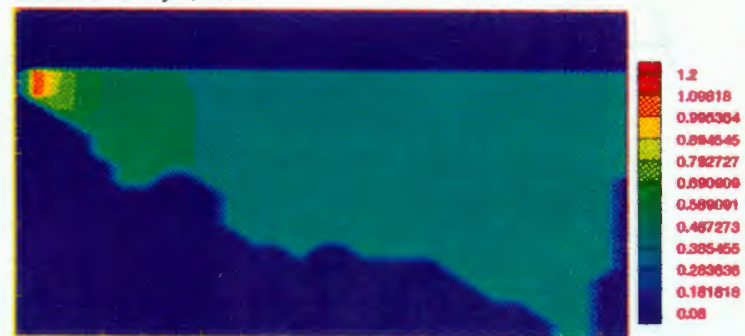

SS5 - May 1, 1990

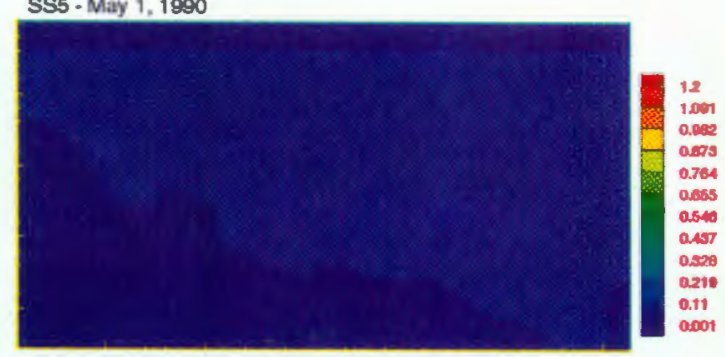

SS5 - July 1, 1990

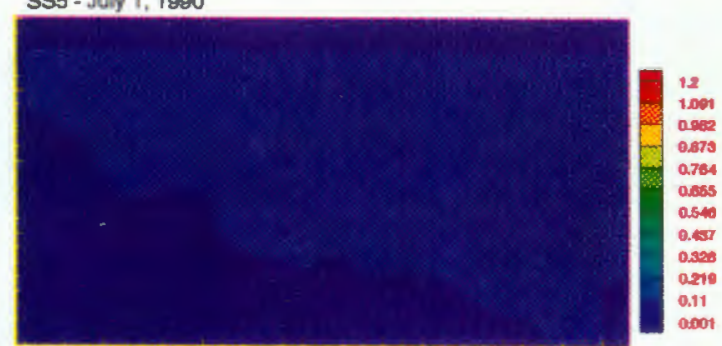

SS5 - March 1, 1990

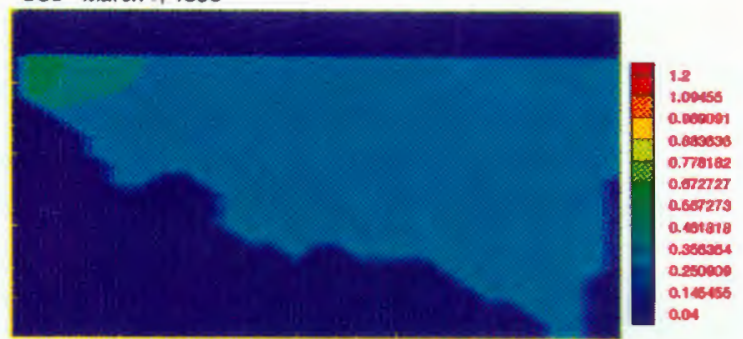

SS5 - June 1, 1990

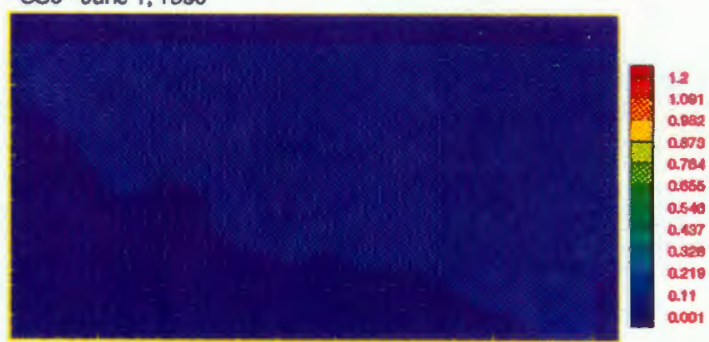

SS5 - September 1, 1990

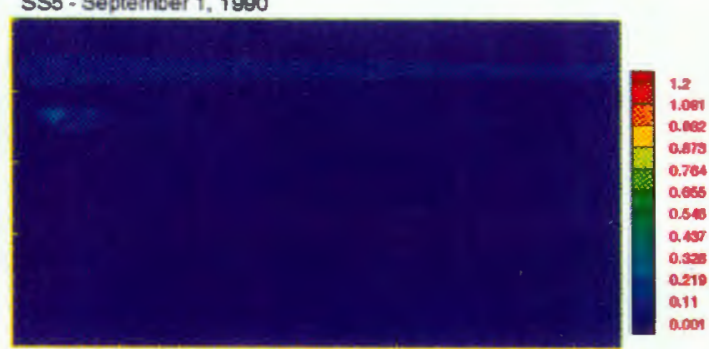

Figure D.5. SS5 suspended solid particle concentration $(\mathrm{mg} / \mathrm{l})$ on February 1st, March 1st, May 1st, June 1st, July 1st, and September 1, 1990. 